University of San Diego

Digital USD

2018-04-16

\title{
Exploring the Relationship between Family Social Capital and Utilization of Well Child Preventative Health Care Services
}

Kristi K. Westphaln

University of San Diego

Follow this and additional works at: https://digital.sandiego.edu/dissertations

Part of the Medical Education Commons, Nursing Commons, and the Social and Behavioral Sciences Commons

\section{Digital USD Citation}

Westphaln, Kristi K., "Exploring the Relationship between Family Social Capital and Utilization of Well Child Preventative Health Care Services" (2018). Dissertations. 114.

https://digital.sandiego.edu/dissertations/114

This Dissertation: Open Access is brought to you for free and open access by the Theses and Dissertations at Digital USD. It has been accepted for inclusion in Dissertations by an authorized administrator of Digital USD. For more information, please contact digital@sandiego.edu. 


\section{UNIVERSITY OF SAN DIEGO}

Hahn School of Nursing and Health Science

DOCTOR OF PHILOSOPHY DISSERTATION PROPOSAL

\section{EXPLORING THE RELATIONSHIP BETWEEN FAMILY SOCIAL CAPITAL AND UTILIZATION \\ OF WELL CHILD PREVENTATIVE HEALTH CARE SERVICES}

By

Kristi Karin Westphaln MSN, RN, CPNP-PC

A dissertation presented to the

FACULTY OF THE HAHN SCHOOL OF NURSING AND HEALTH SCIENCE UNIVERSITY OF SAN DIEGO

In partial fulfillment of the requirements for the degree

DOCTOR OF PHILOSOPHY

April 16, 2018

Dissertation Committee

Eileen Fry-Bowers, PhD, JD, RN, CPNP, Chairperson

Mary Barger, PhD, MPH, RN, CNM, FACNM, Committee Member

Jane Georges, PhD, RN Committee Member 
Hahn School of Nursing and Health Science

DOCTOR OF PHILOSOPHY IN NURSING

CANDIDATE'S

NAME:

Kristi Karin Westphaln

TITLE OF

DISSERTATION: $\quad$ Exploring the Relationship Between Family Social Capital and Utilization of Well Child Preventative Health Care Services

DISSERTATION

COMMITTEE:

Eileen Fry-Bowers, PhD, JD, RN, CPNP, Chairperson

Mary A. Barger, PhD, MPH, RN, CNM, FACNM, Committee Member

Jane Georges, PhD, RN Committee Member 


\begin{abstract}
Background: Passage of the Affordable Health Care Act of 2010 increased insurance coverage for children, however possession of health care insurance doesn't always equate to effective use of health care services. Misuse and underutilization of health care homes is associated with higher costs, fragmentation of health care, and poor health outcomes across the lifespan. Along with reliance upon the health care system, child health and well-being are dependent upon social factors such as interactions with caregivers and communities. Family social capital (FSC) addresses the interrelated nature of child health and family interaction while also promoting family cohesion as currency to stimulate wellness. While high levels of social capital correlate with improved health outcomes including physical health, longer life expectancy, and psychosocial well-being; little is known about the impact of family social capital upon child health care utilization.
\end{abstract}

Purpose: The purpose of this study is to examine the relationship between family social capital and utilization of preventative well-child health care services within a sample of cases of healthy children aged 0-5 years old from the California data within the National Survey of Children's Health (NSCH) 2016.

\title{
Specific Aims:
}

1. Define and analyze the concept of social capital and the extent of the literature surrounding this topic via an evolutionary concept analysis.

2. Describe demographic characteristics including age of child, child designation as male or female, child ethnicity, who lives at home, highest level of education of primary care giver, parent marital status, involvement in organized religion, and type of health insurance; levels of family social capital, and utilization of well-child preventative health care services (defined as frequency of well-child preventative health visits over the past year as gleaned from the survey) in all cases the meet the inclusion criteria within the California subset of the 2016 NSCH. 
3A. Analyze the associations between demographic characteristics, family social capital, and utilization of well-child preventative health care visits.

3B. Analyze the associations between family social capital; specified culture variables; and utilization of well-child preventative health care visits.

4. Examine the relationship of family social capital upon child preventive health care utilization while controlling for statistically significant demographic characteristics.

Methods: The investigator conducted a secondary analysis of data selected from the California subset of data from the $2016 \mathrm{NSCH}$ to examine the relationships between family social capital, utilization of preventative child health care services, and the selected sociodemographic characteristics $(N=257)$

Results: Bivariate associations were investigated between sociodemographic characteristics with utilization of preventative health care services, family social capital variables, and family social capital variables with utilization of preventative health care services. Statistically significant associations were identified between preventative health care utilization and child age (chi-square $=61.9, \mathrm{p}<0.005$, Cramer's $\mathrm{V}=.364$ ) and child race/ethnicity (fisher's exact probability $=15.8$, $p=0.024$, Cramer's V $=0.0 .053$ ), however no correlations were identified between the family social capital variables and utilization of child preventative health care services. Ordinal regression was not conducted due to a lack of significance between the dependent and independent variables.

Implications: While the of this study are inconclusive due to a lack of statistical significance, limitations within the research demonstrate the need for further investigation of the concept of family social capital and its' influence on utilization of health care services. A social capital approach may foster a future of interventions that decrease the costs of health care, promote family empowerment, and enhance health and wellbeing across the life span. 
Copyright 2018

Kristi K Westphaln

All Rights Reserved 


\section{Dedication}

"Their voices were heard! They rang out loud clear and clean.

And the elephant smiled. Do you see what I mean?

They've proved they ARE persons, no matter how small.

And their whole world was saved by the Smallest of All!"

Dr. Seuss, Horton Hears a Who, 1954 


\section{Acknowledgements}

"Unless someone like you cares a whole awful lot,

Nothing is going to get better. It's not."

Dr. Seuss, The Lorax, 1971

My research involving the social influences that impact health continues to solidify my belief in the power of connection. Thank you for believing in me.

Parents: Karin and Richard Westphaln

Grandparents: Lotte and Carl Wulf, Elaine and George Westphaln

Siblings: Karri and Ricky Westphaln, Bridget Vasquez

Nephew: Mason Sieng

Dog: Grouper

Chair: Eileen Fry-Bowers

Committee Members: Mary Barger and Jane Georges

Fairy Godmother: Patricia Roth

First Pediatric Nursing Professor: Lorie Judson

Mentors: Diana Mason, Eufemia Jacob, Nancy Pike,

Sunny Hallowell

Friends and Co-conspirators: Barbara Glickstein, Nancy McGrath, Cat Goodhue, Eve Adler, Katherine Ferris, Martha Fuller, Julie Graham, Melodie Daniels, Caroline Serrano, Lisa Alvarez, Deanna Johnston, Razel Milo, Ricky Padilla, Katherine Baker, Jaspal Gill, Liz Boulette, Arlin Ramira, Kiiyonna White.,Cheryl Boyd, Dorothy Syoc, Dorothy Forde, Ann Mayo, Susan Bonnell, Bob Topp, Valerie Willis, Stuart Cohen, Anita Pinto, Sarah Judd, Sharee Anzaldo, Kenya Beard, Dale Glaser, Sara Loughead, Stacy Bright

California State University Los Angeles, School of Nursing

University of California Los Angeles, School of Nursing

The George Washington University, Center for Health Policy and Media Engagement

University of San Diego, Hahn School of Nursing and Health Science

Children's Primary Care Medical Group of San Diego

Rady Children's Hospital of San Diego

Children's Hospital of Los Angeles 


\section{Table of Contents}

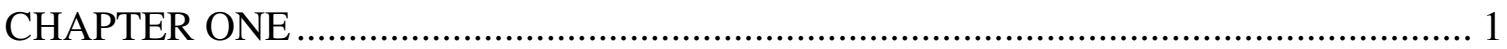

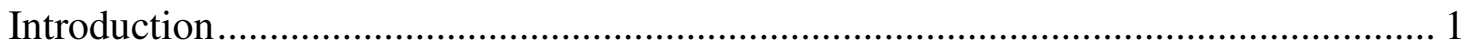

Child Health Trends in the United States …………................................................... 1

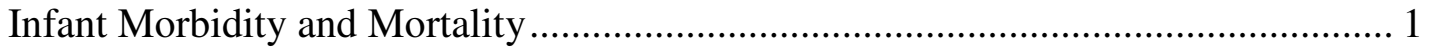

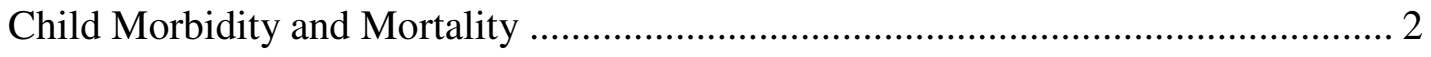

Health Behaviors during Childhood and Adolescence ................................................. 3

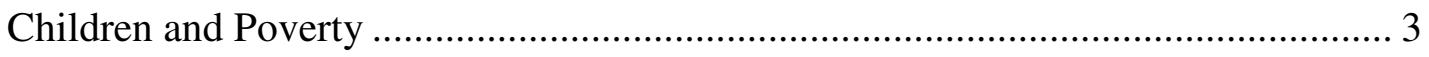

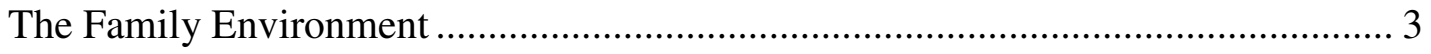



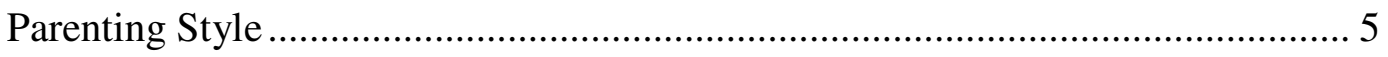

Family Socioeconomic Status (SES) and young children .......................................... 5

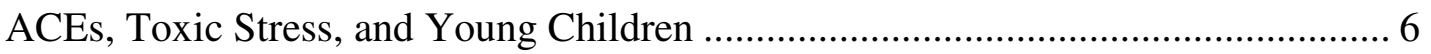

Child Health, Access to Health Care, and Utilization of Health Care Services ............. 7

Family Social Capital.................................................................................... 9

Social Capital and Child Health Care Utilization ...................................................... 10

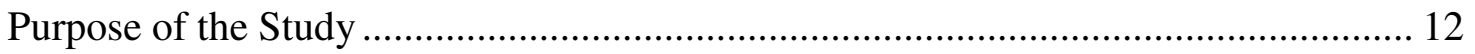

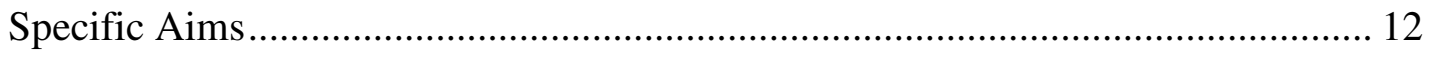

Systematic Reviews Investigating Social Capital in Health Science Research........ 14

Social Capital and Health Care Access............................................................... 14

Social Capital and Socioeconomic Inequalities ...................................................... 17

Family Social Capital and Health ...................................................................... 19

Social Capital, Family social capital, and Measurement .......................................... 22

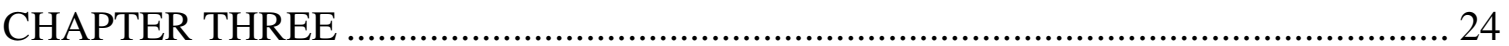


Introduction

Social Capital: Definition, ecological framework, dimensions, approaches 24

Levels of Social Capital: An Ecological Framework

Bonds that connect the Levels of Social Capital .................................................. 25

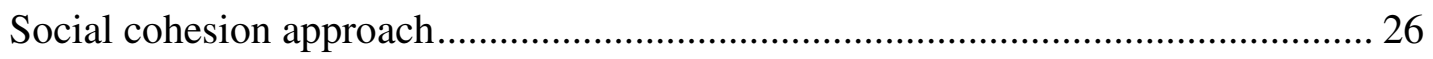





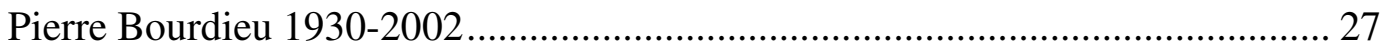

James Coleman 1926-1995 …..................................................................... 27

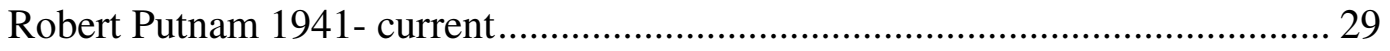

Multidisciplinary Uses of Social Capital ....................................................... 30

Social Capital and Sociology ................................................................. 30



Social Capital and Political Science ......................................................... 31

Social Capital and Health........................................................................... 33

Social Capital and Nursing: A concept analysis ............................................... 34

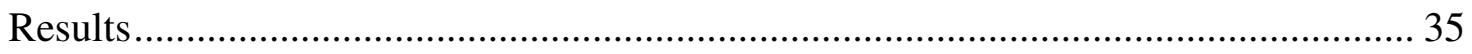

Thematic Breakdown by Type of Study ........................................................ 35

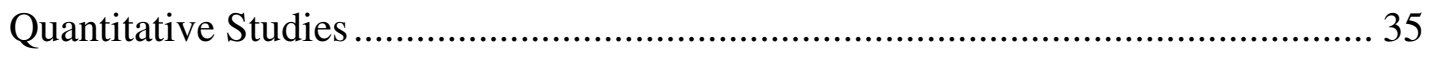

Framework/Conceptual Analysis Papers ...................................................... 36

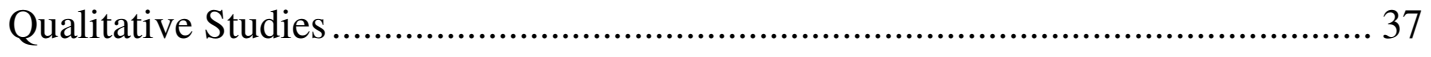

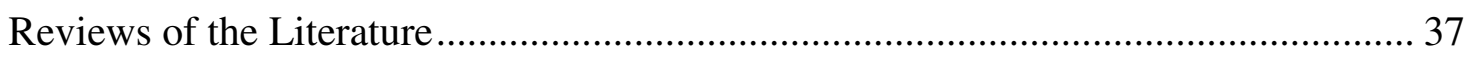

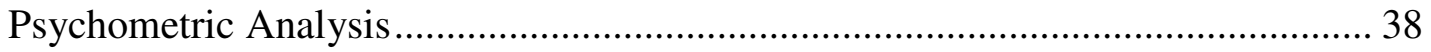


Evidence Based Practice ........................................................................................ 38

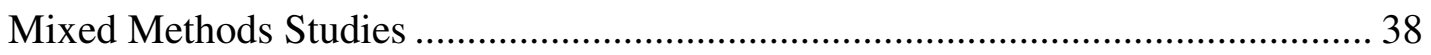

Attributes for Social Capital within a Nursing Context............................................... 39

Antecedents and Consequences of social capital..................................................... 39

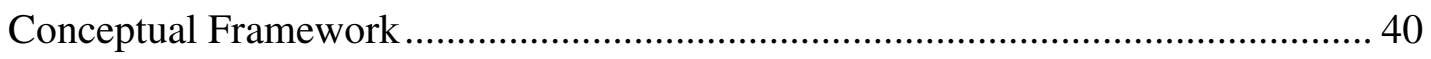

James Coleman and Family Social Capital.............................................................. 40

Critiques of Coleman's Conceptualization of Family Social Capital........................ 41

Anderson's Behavioral Model of Health Care Utilization ........................................ 43

Life Course Health Development Theory ................................................................ 43

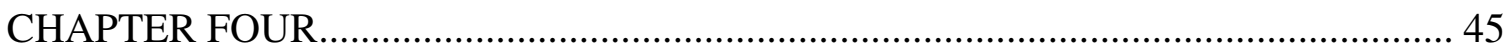

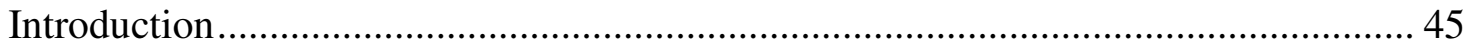

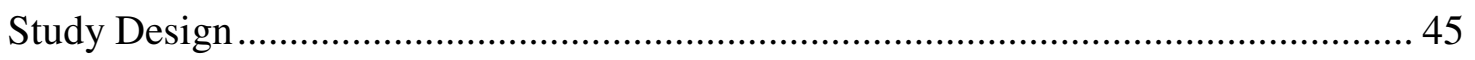

The 2016 National Survey of Children's Health (NSCH) ....................................... 45

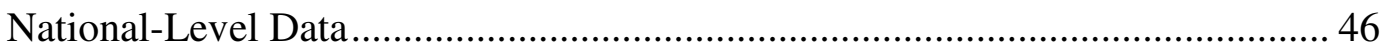

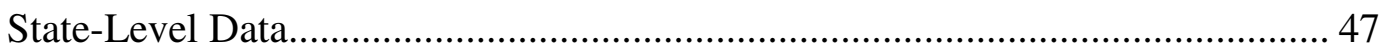

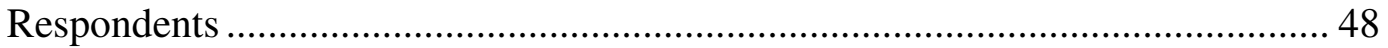

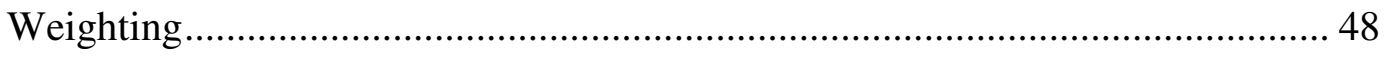

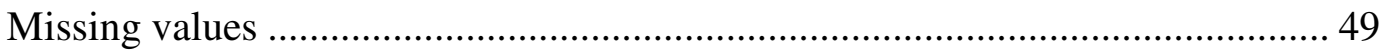

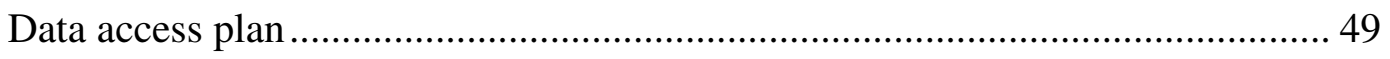

Protection of Human Subjects .......................................................................... 50

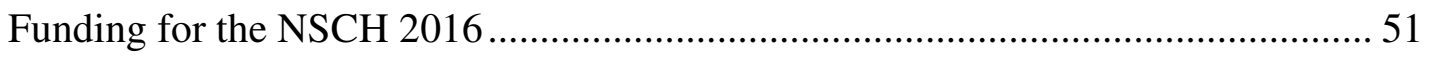

Sampling Procedures, Inclusion Criteria, Exclusion Criteria …………………….... 51

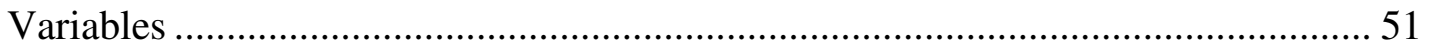


Preventative health care utilization



Sociodemographic Characteristics............................................................. 53

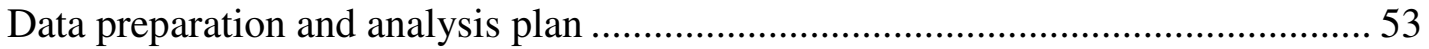

Child and family sociodemographic characteristics ..................................... 55

Family culture characteristics ............................................................ 56

Dependent variable: Preventative health care utilization................................ 59

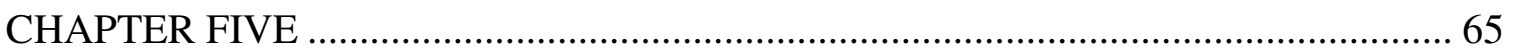

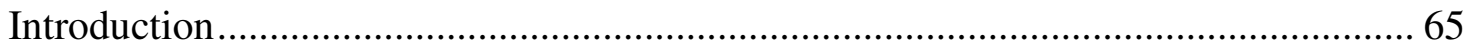

Commentary regarding secondary analysis of preexisting data ...........................6 66

The 2016 National Survey of Children's Health: A Critical Analysis ..................... 67

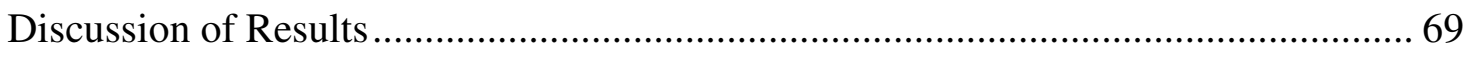

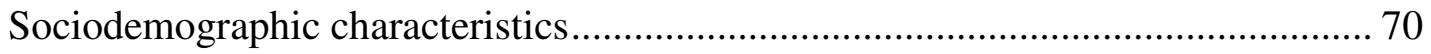

Missing data: Emotional Support from place of worship ................................... 70



Dependent and Independent Variables ...................................................... 72

Preventative Health Care Utilization ...................................................... 73

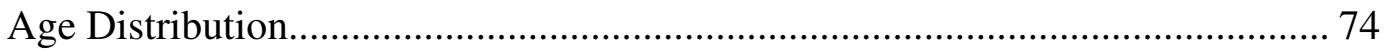

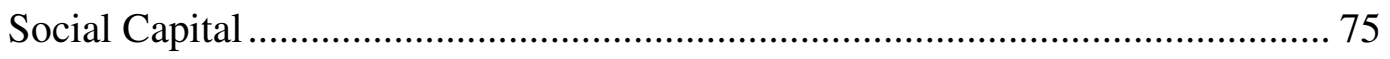

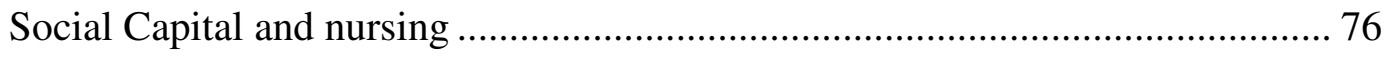

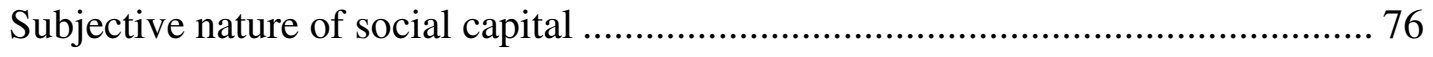

Multiple definitions of social capital .......................................................... 77

Controversy in measuring social capital ..................................................... 77 
Social capital in the nursing workforce

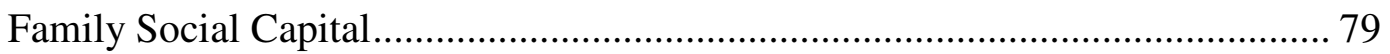

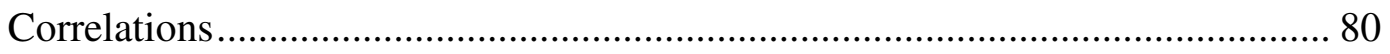

Implications for Health Policy ............................................................................ 81

Demographic trends involving children and families in the United States .......... 81

The economic impact of disadvantaged environments ....................................... 81

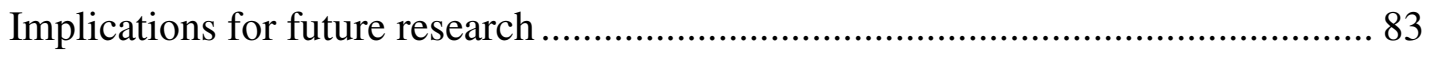

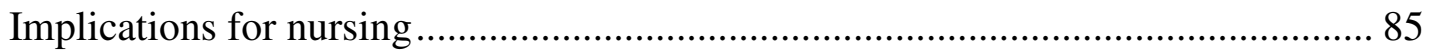

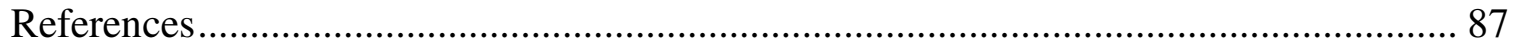




\section{List of Tables}

Table 1. Literature table of quantitative studies involving social capital and nursing ................ 102

Table 2. Literature table of framework/concept studies involving social capital and nursing..... 121

Table 3: Literature table of qualitative studies involving social capital and nursing ................. 143

Table 4: Literature table of review of literature papers involving social capital and nursing...... 148

Table 5: Literature table of articles using psychometric analysis involving social capital and

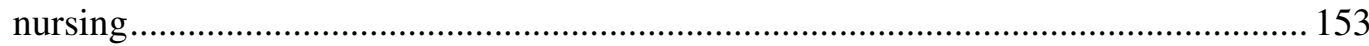

Table 6: Literature table of evidence-based practice articles involving social capital

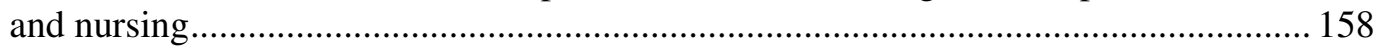

Table 7: Literature table of mixed methods articles involving social capital and nursing........... 161

Table 8. Quantitative Measurement Modalities for Social Capital in the Nursing Literature ..... 163

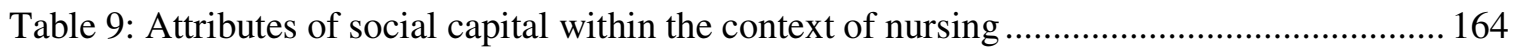

Table 10. Critical Attributes of Social Capital: Cognitive Domain ............................................ 165

Table 11. Critical Attributes of Social Capital: Behavioral Domain .......................................... 166

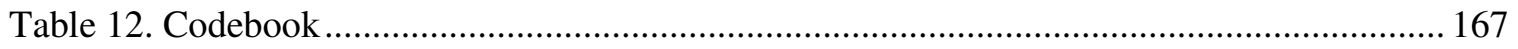

Table 13. Child and family sociodemographic characteristics ............................................... 172



Table 15a. Family social capital: Cognitive domain ............................................................. 175

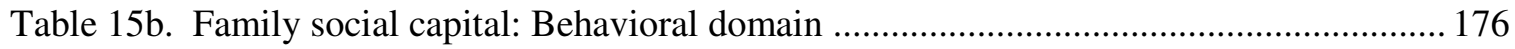

Table 16a. Visits with physician or other health care provider for preventative health care services

Table 16b. Visits with physician or other health care provider for preventative services per age of child

Table 16c. Preventative health care utilization per age recommendations 178

Table 17a. Bivariate analysis of preventative visits with health care provider over past 12 months and sociodemographic characteristics

Table 17b. Bivariate correlation matrix for family social capital variables 180

Table 17c. Bivariate analysis of preventative visits with health care provider over past 12 months and family social capital variables 


\section{List of Appendices}

Appendix A: Levels and bonds of social capital .................................................... 181

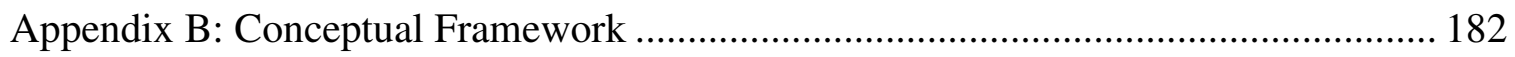






\section{CHAPTER ONE}

\section{Introduction}

The current state of child health in the United States holds implications for future adult wellness and productivity. The Life Course Health Development (LCHD) theory posits that health disparities originating in childhood perpetuate poor health trajectories across the life span and that negative exposures during critical points during the life span can be mitigated via positive protective factors (Halfon, 2016; Levy \& Sidel, 2013; Shonkoff, Garner, The Committee on psychosocial aspects of child and family health, \& The Committee on early childhood, adoption, \& dependent care, 2012). Research supports that health investments within critical "sensitive" time periods of childhood lead to compounded gains in both health potential and health reserves (Heckman, 2013; Felitti et al., 1998; Halfon, 2016; Shonkoff et al., 2012). Childhood experiences and exposures affect adult health outcomes and the quest to improve American health must include a greater consideration of critical "sensitive" time periods of health development across the life span (Institute of Medicine and National Research Council, 2013). The current state of infant morbidity and mortality, child morbidity and mortality, and pediatric health behavior trends are not reassuring.

\section{Child Health Trends in the United States}

\section{Infant Morbidity and Mortality}

The United States has a higher incidence of prematurity, low birth weight, and poor maternal health when compared with other peer high-income, developed countries. With an infant mortality rate of 6.1 infant deaths per 1,000 live births (Institute of Medicine and National Research Council, 2013), the United States ranks 26th among 
other high- income developed countries (Organization for Economic Co-operation and Development [OECD], 2001). Adverse birth outcomes disproportionately affect minority groups in America; however, evidence supports that the poor birth outcomes in the United States cannot be fully explained by ethnic or racial diversity (Institute of Medicine and National Research Council, 2013). Additionally, adolescent pregnancy and poverty represent significant antecedents that contribute to high infant mortality rates (Institute of Medicine and National Research Council, 2013).

\section{Child Morbidity and Mortality}

American children who survive infancy continue to demonstrate poorer health and wellness than other peer high-income developed countries. Halfon, Wise, and Forrest (2014) suggest that $30 \%$ of young children have developmental or behavioral problems, $40 \%$ of children who show up for kindergarten aren't ready, and $22 \%$ of adolescents experience mental and behavioral health disorders that adversely affect school performance and/or participation in desired activities. (Blanchard, Gurka, \& Blackman, 2006; Isaacs, 2012). Preventable injuries including falls, motor vehicle accidents, and drownings remain leading causes of morbidity and mortality in children over one year of age (Centers for Disease Control and Prevention [CDC], 2017). Violence also remains a significant cause of pediatric death and disability (CDC, 2017). Of 17 OCED peer countries, the United States has one of the highest rates of child mortality due to physical assault, negligence, or maltreatment (Institute of Medicine and National Research Council, 2013). Child homicide and suicide remain on the rise (CDC, 2017). 


\section{Health Behaviors during Childhood and Adolescence}

Many adult chronic health conditions including type 2 diabetes, cardiac disease, and cancers are linked to unhealthful life habits and modifiable risk factors that are established in childhood and adolescence (Institute of Medicine and National Research Council, 2013). These comorbidities contribute to poor adult health outcomes. American adolescents experience higher rates of obesity, pregnancy, mental illness, sexually transmitted infections, and injuries than teens in other OCED countries (Institute of Medicine and National Research Council, 2013).

\section{Children and Poverty}

Children living in poverty remain at the highest risk for poor health care, poor access to care, and poor health outcomes. (Carter, 2014; Levy \& Sidel, 2013; Rosenbaum \& Blum, 2015). Pediatric functionality is traditionally measured by attainment of developmental milestones, play, school performance, and activities of daily life. Poverty has direct detrimental forces upon all of these measures (Cheng, Emmanuel, Levy, \& Jenkins, 2015). Stressors of poverty that adversely affect child health include poor nutrition, unstable family structure, unreliable living conditions/environmental hazards, and poor access to health care (Levy \& Sidel, 2013). Health disparities that originate in childhood lead to adult chronic illnesses; impoverished adults with poor health have difficulty providing for their children, and the cycle perpetuates (Halfon, Larson, Lu, Tullis, \& Russ, 2014).

\section{The Family Environment}

Evidence supports that the family environment represents one of the most influential health-related life exposures during the first five years of life (Shonkoff et al., 
2010; Halfon, 2016). Defined as cohesive units with clearly delineated boundaries between the community and the family, families create a structural foundation for children. In addition, families represent a key life setting within which young children receive care and socialization (Looman, 2006; Wen, 2008). Family structure (who lives at home) contributes to family characteristics and family functioning, thereby influencing child accrual of resources that are essential for healthy child growth and development. Research supports that children who are exposed to strong, warm, and loving family and community connections grow into confident, caring, considerate, and competent youth (Duke, Skay, Pettingell, \& Borowsky, 2009). Additionally, youths from supportive families demonstrate decreased risk-taking behaviors during adolescence (Duke et al., 2009).

Children with membership within a two-parent or caregiver family structure are at a distinct advantage over single parent families. Marriage rates are declining, divorce rates are climbing, and approximately $40 \%$ of children born in the United States are born to unwed parents (CDC, 2017) (McLanahan, Haskins, Garfinkel, Mincy, \& Donahue, 2010). Societal stigma is diminished surrounding premarital intercourse, co-habitation, and having children while unmarried (McLanahan et al., 2010; Taylor, Funk, \& Clark, 2007). Results from original and collaborative research from the Fragile Families Child Wellbeing Study continue to demonstrate that disproportionate disparities, inequities, and economic inequalities exist for children born to unmarried parents versus their married counterparts (Kalil \& Ryan, 2010; Hummer \& Hamilton, 2010; McLanahan et al., 2010; Waldfogel, Cragigie, \& Brooks-Gunn, 2010). Along with family structure, family 
relationships and socioeconomic status represent important components that influence child health and wellness.

\section{Family Relationships}

Parenting Style: Research supports high-tension parent-child relationships and negative parenting behaviors, such as harsh discipline or rejection, are associated with negative physiological and psychological health outcomes for children including poor social skills, low levels of self-worth, behavioral problems, poor mental health, and decreased goal orientation (Conger et al., 1992; Elder, Nguyen, \& Caspi, 1985; Lempers, Clark-Lempers, \& Simons, 1989; Wen, 2008) Often, economic strain and social pressures represent key triggers that may initiate negative parenting behaviors and/or poor parent health (Barrett \& Turner, 2005; Wen, 2008).

\section{Family Socioeconomic Status (SES) and young children}

Family socioeconomic status (SES) additionally "gets under the skin" and influences child health, development, and well-being. A systematic review analyzing socioeconomic disparities in adverse birth outcomes demonstrated a significant association between SES and birth outcomes within 93 of the 106 papers that were included in the study (Blumenshine, Egerter, Barclay, Cubbin, \& Braveman, 2010). Additionally, positive associations were reported between SES and birth outcomes with increased prevalence of adverse outcomes among the least advantaged groups (Blumenshine et al., 2010).

Evidence links family SES to child health and well-being; however, it does not predict family cohesion (Coleman, 1990; Thompson, Hanson, \& McLanahan, 1994). Impoverished families may possess little financial wealth yet feature engaged parents and 
strong family connections. Affluent families may possess large amounts of financial assets but may also have lower levels of interaction due to busy and/or disengaged parents. Wen (2008) additionally found that protective effects of family SES were not equally generalizable across all ages and stages of child development. Family income was more protective from health conditions for younger children and less protective for adolescents (Wen, 2008).

\section{ACEs, Toxic Stress, and Young Children}

Exposure to negative parenting and/or adverse childhood experiences may have a lasting effect upon child health and wellness trajectories. Seminal studies in the 1980s by Barker (1998), Wadsworth(1987, Forsdahl (1977) and others contributed to the creation of a body of evidence linking fetal experiences to adult health (Halfon, Larson, Lu, Tullis, \& Ross., 2014; Shonkoff et al., 2012). The adverse childhood experiences (ACEs) series of research then ignited an exploration into the relationship between early childhood exposures and health outcomes across the life span (Felitti et al., 1998).

The original ACEs study was conducted as a survey of 17,421 adults (Felitti et al., 1998). Participants were provided with a questionnaire detailing 10 categories of childhood exposures including neglect, physical abuse, sexual abuse, emotional abuse, lack of family support, witness to domestic violence, death of a parent, family member incarceration, family member with mental illness, or a family member with substance abuse. Retrospective data analysis yielded an association among ACEs, health, and wellness (Felitti et al., 1998). Additional cycles of research on ACEs continued to support the enduring neurobiological damage and subsequent life-long negative effects associated with exposures to adverse childhood experiences (Anda et al., 2006). 
Research continues to support that prolonged exposure to toxic stress permanently alters child brain structure and function including decreased hippocampal volume, hypertrophy of the amygdala, atrophy of the pre-frontal cortex, and loss of neurons (Shonkoff et al., 2012). These functional alterations result in consequences including memory impairment, hyper activation of the stress response, mood dysregulation, and learning disabilities (Shonkoff et al., 2012).

While brain plasticity during the first five years of life makes young children very susceptible to damaging mechanisms, this also infers that they are additionally susceptible to the effects of positive protective mechanisms. Animal research by Meaney (2001, 2010) reveals associations between hippocampal resilience and responsive maternal behaviors (Luby et al., 2013). Luby et al. (2013) utilized neuroimaging to evaluate the relationship among hippocampal volume, children, and stressful surroundings. Findings revealed that nurturing parenting behaviors held the capacity to buffer the negative effects of stressful environments upon the hippocampus in children (Luby et al., 2013).

\section{Child Health, Access to Health Care, and Utilization of Health Care Services}

Childhood is a sensitive and critical time period, with child health strongly influenced by individual factors, social determinants of health, and the family environment (Halfon, 2016; Shonkoff et al., 2012). As children depend upon their caregivers to meet their basic needs, they additionally rely upon caregivers for access to the health care delivery system (Kominski, 2014). Engaged caregivers and possession of health insurance are essential for children to access and utilize services including wellchild preventative health care services (WCC), acute health care services such urgent or 
emergency care visits, and other specialty health care related services (Wisk \& Witt, 2012).

The health care needs of children vary significantly from the adult population. Children possess a unique set of developmental vulnerabilities and experience different patterns of morbidity and mortality than adults (Burns et al., 2017). These special needs have prompted organizations such as the American Academy of Pediatrics(AAP) and the Maternal Child Health Bureau to champion high quality pediatric health care as comprehensive, continuous, coordinated, and accountable (Institute of Medicine and National Research Council, 2013). Multiple organizations including the AAP, Agency for Healthcare Research and Quality (AHRQ), and National Research Council and Institute of Medicine continue to explore child health specific performance measures and standards for optimum child health care. The majority of pediatric health advocacy and research organizations agree that regularly scheduled health care is essential for optimum child health and development.

Regularly scheduled health care for children in the United States is characterized by health maintenance visits, or well-child care (WCC) visits that focus on promoting and sustaining child health. Sites that children seek for regular health care may vary; however, AAP Bright Futures Guidelines provide comprehensive recommendations for optimum pediatric health supervision (AAP, 2017b). These recommendations describe frequency of visits, immunization schedules, health surveillance, and anticipatory guidance that support health and wellness for children. A copy of the Bright Futures Recommendations for Preventative Pediatric Health Care can be accessed at https://www.aap.org/en-us/documents/periodicity_schedule.pdf. 
While the Bright Futures Guidelines represent the gold standard for pediatric health maintenance visits, variation exists among what services are covered throughout the many types of insurance plans in the United States. Consequences resulting from delayed care such as health diagnoses, referrals for early intervention, vaccination administration, and/or health maintenance care adversely impact child health and exacerbate poor health trajectories across the life course (Alpern et al., 2014; Halfon, 2016). Therefore, optimum child health outcomes also require insurance coverage that provides children with access to preventative health care services (Kominski, 2014).

Health disparities persist in the pediatric population. Individual, family, and environmental exposures impact child health. While $95 \%$ of children in the United States have health insurance via medicaid, the children's health insurance program (CHIP), and provisions of the ACA; possession of health care insurance does not always equate to equal access nor efficient utilization of pediatric preventative health care services (Kominski, 2014). Innovative solutions are needed to better understand the social factors that influence utilization of child preventative health care services and child health.

\section{Family Social Capital}

The concept of social capital refers to the resources obtained via membership and interaction within social networks (Bourdieu, 1986; Coleman, 1990; Putnam, 2000). These networks are defined within a socioecological framework that encompass family, community, and governmental levels. As the first five years of life are considered the most formative within child growth and development, the family level of social capital offers a unique perspective regarding the exchanges and resources affiliated with the family environment (Field, 2017). Coleman (1990) perceives family social capital as an 
important pathway for children to access the financial and human capital assets within their family environment. The notion of "family social capital" addresses the interrelated nature of child health and family interaction while also promoting family cohesion as currency to stimulate wellness (Alvarez, Kawachi, \& Romani, 2017; Coleman, 1990; Hsieh, 2008; Looman \& Lindecke, 2005).

\section{Social Capital and Child Health Care Utilization}

Few empirical research studies explore the association between social capital and health care service utilization. Story (2014) utilized the 2005 Indian Human Development survey to conduct a multilevel (individual, household, and community) analysis of the association between social capital and utilization of maternal and child health services in India. A total of 10,739 women from 2,293 villages across India were included in the study. Child health service utilization was assessed by analyzing the youngest child aged zero to five from the sample of women included in the study. Study dependent variables included frequency of attendance at maternal antenatal check-ups during the most recent pregnancy, if the most recent birth received assistance from a health care professional, and child vaccination status by 12 months of age. The study independent variable of social capital was measured by a composite variable composed of social cohesion and network elements and was constructed via exploratory factor analysis. Results of the study revealed an association between social capital and utilization of maternal child health care services at the community level. Children who lived in communities with stronger group ties were more likely to have higher levels of vaccine completion. Additionally, the study suggests that bonding social capital may exert contextual effects upon maternal child health care utilization. One of the greatest limitations of this study is 
a failure to report the reliability, validity, and significance levels regarding the measurement of social capital. This is consistent with many of the studies that use selfcreated measures of social capital; therefore, results must be interpreted with caution and a causal association cannot be inferred.

Harpham, De Silva, and Tuan (2006) hypothesized that higher levels of maternalreported social capital would correlate to higher child health. A randomized sample of children was selected and their mothers were subsequently identified from the Young Lives project across 33 communities and 5 provinces in Vietnam. A modified version of the social capital assessment tool (A-SCAT) was used to measure social capital. While the study claims that the A-SCAT questionnaire is psychometrically validated in Vietnam, the reliability and validity is not clearly presented in the research article. Child health indicators were divided into short-term health, long-term health, and nutritional status. Within this study, social support and cognitive indicators of social capital yielded the greatest significance towards child health for children less than one year of age. Additionally, community social support was associated with healthy weight for age and nutritional status for one-year-old children. Membership in groups and civic involvement was not significantly associated with child health.

Both Story (2014) and Harpham et al. (2006) refer to "household social capital" and recommend further exploration of this level of social capital as a means to influence child health. While there is a significant body of work that explores the association between health and social capital, very little research addresses the association between family level social capital and child health. Access and utilization of preventative child health care services both represent important variables that influence child health, yet 
even fewer studies evaluate this association. This study seeks to bridge the gap between family level social capital and utilization of child preventative health care services.

\section{Purpose of the Study}

The purpose of this study is to examine the relationship between family social capital and regular utilization of preventative child health care services within the California subset of unweighted cases of children aged 0-5 years old from within the 2016 National Survey of Children's Health (NSCH).

\section{Specific Aims}

1. Define and analyze the concept of social capital and the extent of the literature surrounding this topic via an evolutionary concept analysis.

2. Describe sociodemographic characteristics including child age, child gender, family structure, use of church for emotional support, perceived difficulty in obtaining basic family needs, highest level of education of the adults living in the household, insurance status, child born in the United States, adult caregiver respondent born in the United States, household generational status, language spoken at home, child race, family social capital, and utilization of well-child preventative health care services (defined as attending no visits, one visit, or two or more visits over the past year as gleaned from the survey) in all cases within the unweighted California subset of the 2016 National Survey of Children's Health.

3. Analyze the associations between sociodemographic characteristics, family culture characteristics, family social capital, and utilization of well-child preventative health care visits within the study population. 
Hypothesis 1 . There will be statistically significant associations between the specified demographic characteristics, family social capital, and utilization of well-child preventative health care visits.

4. Examine the relationship of family social capital upon child preventive health care utilization while controlling for statistically significant demographic characteristics in the study population.

Hypothesis 1 . There will continue to be a statistically significant association between family social capital and utilization of well-child preventative health care services. 


\section{CHAPTER TWO}

\section{Introduction}

Chapter two of this dissertation includes a comprehensive review of the literature involving family social capital and health. A review of the empirical literature involving social capital and health care over the past 20 years yielded three key systematic reviews that provide further insight into the definitions, utility, and gaps involving social capital in health care research. These three pertinent systematic reviews will be analyzed, additional relevant literature will be reviewed, and further detail will be provided regarding the measurement of social capital.

\section{Systematic Reviews Investigating Social Capital in Health Science Research}

Social Capital and Health Care Access. Factors that influence individual interaction with the health care system are traditionally focused on characteristics including sociodemographics, health status, and insurance coverage (Derose \& Varda, 2009; Kominski, 2014). However, growing evidence suggests that contextual factors beyond the individual level also play a role in understanding utilization of health care services. Kirby and Kaneda (2005) found a negative relationship among having a regular source of health care, attending regular preventative health maintenance visits, and residing in low-resourced communities. Additionally, a positive relationship was noted between living in low-resourced communities and having unmet health care needs (Kirby \& Kandea, 2005). During an exploration of health care utilization and neighborhood, Law et al. (2005) discovered an association among neighborhood, unmet health care needs, and physician visits. Neighborhood location was also associated with variance of health care utilization across genders (Law et al., 2005). 
Derose and Varda (2009) conducted a systematic review to further explore the relationship between social capital and access to health care. A review of the literature involving social capital and health care access was conducted across 15 databases. Boolean search terms and phrases included social capital, social cohesion, social context, social environment, social disorganization, neighborhood cohesion, accessibility, utilization, health care, health services, and access. The initial review identified 2,396 abstracts. After applying the inclusion criteria of a quantitative or qualitative empirical research study and involvement of social capital and a health outcome, 21 papers met the criteria for analysis. A table of the empirical studies of social capital and health care access from this study can be assessed in the systematic review published by Derose and Varda (2009).

Results of the analysis yielded themes involving the research design, methodology, and results. A cross-sectional quantitative design was the most common research design. Six of the studies utilized a nationally representative or multiple-city sample, 11 studies featured representative samples from a single city/region/state/country/province, and four of the studies utilized a convenience sample comprising ethnic minority groups. Additionally, the quantitative studies varied across the levels of variables; 11 used a multilevel design featuring an individual level dependent variable and community level independent variables, seven featured both the independent and dependent variable at the individual level, and one study measured social capital and health care at the province level.

Derose and Varda's (2009) systematic review of the literature involving social capital and health care access reveals wide variation in the measurement of social capital. 
Fourteen of the quantitative studies analyzed in this review used author-constructed scales with various individual and/or aggregate level measures. A potential consequence of using author-generated instruments without psychometric analysis is a lack of conceptual clarity; some of the studies featured contradictory and/or negative results among outcomes and social capital indicators and others posited collinearity between neighborhood socioeconomic variables and social capital variables. Two of the studies used previously developed scales by Sampson, Raudenbush, and Earls on social cohesion, trust, and informed social control; however, these studies lacked consistency regarding variable selection. Only one study in this systematic review reported psychometric properties. Ahern and Hendryx (2003) created a social capital scale including social trust, self-esteem, civic engagement, voting rates, per capita crime rate, and per capita contributions to United Way as a proxy for generalized reciprocity. The study reported a Cronbach's alpha of 0.76 (Derose \& Varda, 2009).

The results of Derose and Varda's (2009) systematic review of the literature on social capital and health care access reveal an abundance of quantitative studies with a cross-sectional design, a preference for researcher-developed summary scales, use of multiple indicators to measure social capital, and multilevel assessments. Additionally, the systematic review reveals that the literature investigating social capital and health care access lacks qualitative studies, a clear and concise definition of social capital, conceptual frameworks within the studies, and measurement modalities that have undergone psychometric analysis.

Multiple recommendations are provided to improve and expand the use of social capital in health science literature (Derose \& Varda, 2009). One of the challenges 
identified in the conceptualization of social capital is the challenge of differentiating between antecedents and consequences. Along with the consensus of the current social capital research community, Derose and Varda (2009) agree that a combined social cohesion and network approach is required to distinguish between the resources from social capital and the benefits derived from it. From this, they recommend further indepth theory work with an expansion of the dimensions of social capital to include cognitive (what people feel), behavioral (what people do), and structural (network measures such as strength of ties, redundancy of interactions, and density) dimensions. None of the studies in the systematic review made any distinction among different types of bonds within social capital.

While this systematic review is primarily focused on the community level of social capital, it does hold implications regarding the family social capital. A glaring gap is noted in the empirical investigation at the family level of social capital. The wide range of conceptual ambiguity expands across disciplines and represents a root cause for the lack of a uniform mode for measurement. However, it also identifies the opportunity to drive research efforts to derive instruments for social capital measurement that incorporate rigorous psychometric analysis. Further qualitative investigation of the concept of social capital may also be useful to glean further insight to guide instrument development.

\section{Social Capital and Socioeconomic Inequalities}

Research investigating social capital and health continued to expand, evidence continued to support a connection between social capital and health, and an additional systematic review was published in 2013 addressing the relationships between social 
capital and socioeconomic inequalities in health (Uphoff, Pickett, Calbeses, Small, \& Wright, 2013). Uphoff et al. aimed to explore the hypothesis that social capital mediates the association between income inequality and health. A systematic review of the literature was performed via the PRIMSA guidelines. Boolean phrases including health inequalities, social capital and socioeconomic status were searched across CINAHL, Cochrane, EMBASE, and MEDLINE. The initial search produced 618 studies. The screening process then involved removing duplicates, reviewing abstracts by two separate authors, conducting a full text review, and performing data extractions. Studies were omitted from the systematic review if they were duplicates or failed to include the key terms of social capital, socioeconomic inequalities, and health. The final analysis involved 60 studies from a wide variety of countries.

The majority of the studies were cross-sectional and utilized self-reported data from large surveys. Sixteen of the studies had sample sizes that exceeded 8,000 subjects. Consistent with the findings of Derose and Varda (2009), social capital was most commonly measured via multiple indicators and lacked clarity of rationale for selecting indicators and reporting of psychometric properties. Social capital was most commonly measured throughout the sample of articles at the individual and community levels of social capital.

Of the 60 studies, 56 demonstrated a three-way correlation among social capital, health, and socioeconomic status. Forty-one of the studies emphasized the correlation without mentioning interaction effects. A total of 19 studies tested for interaction effects of socioeconomic inequalities and social capital in health. Further details regarding these 
19 studies can be found in Tables 1 and 2 in Uphoff and colleagues' (2013) systematic review.

Results of the systematic review exploring social capital and socioeconomic inequalities confirm the association among socioeconomic inequalities, social capital, and health (Uphoff et al., 2013). Evidence from the 60 articles included in the systematic review supports that individuals with lower socioeconomic status have lower levels of social capital. A second key finding suggests that social capital within tight knit communities plays a role in buffering the negative effects of low socioeconomic status upon health. Studies that supported this hypothesis measured social capital at the individual level and the buffer effects were noted to have increased effect within lowresourced communities and among ethnic minorities. Finally, Uphoff et al. (2013) caution that while social capital may hold the capacity as a buffer for negative health outcomes, disadvantaged groups may have limited opportunities to access, foster, and obtain social capital. Gaps in the literature are identified within the areas of family social capital and the buffering capacity of social capital. Additionally, further research is needed to better understand the potentially helpful and harmful implications of social capital.

\section{Family Social Capital and Health}

A systematic review by Alvarez et al. (2017) examined the presence of family social capital within the health literature, specifically within the context of conceptualization and operationalization. Alvarez et al. (2017) applied the key search terms of "family" and "social capital" to the Web of Science, PubMed, and Sociological Abstracts databases. No time limitation was set. Inclusion criteria for this systematic review specified that the study must be a quantitative research article, measure social 
capital within the family level, feature a documented health outcome, and possess full text availability. (Alvarez et al., 2017). The initial search result yielded 718 references, of which 30 met the criteria for inclusion in the systematic review.

All of the studies within the systematic review of family social capital and health contained either a social cohesion, network, or dual perspective conceptualization of social capital (Alvarez et al., 2017). In review, social cohesion scholars traditionally emphasize closeness within groups (such as trust or belonging), whereas network scholars emphasize the resources obtained by individual group members (Alvarez \& Romani, 2017; Kawachi, Subramanian, \& Kim, 2010). Life stage and age influenced the conceptual approach for the studies, with health-related research involving family level social capital in elders utilizing a network approach and research involving social capital and youth favoring a social cohesion approach. The studies exploring family social capital, health, elders, and/or people with disabilities embodied a network-based approach as to promote individual capacities and social support (Alvarez et al., 2017).

It has been almost 20 years since Coleman (1990) introduced the concept of family social capital, yet the majority of research on social capital and health is focused on other structural levels (Alvarez et al, 2017). Putnam's (2000) research on social capital and social engagement is focused upon the national level. Additional research at the national level investigates population health, income equality, and psychosocial environments (Lynch et al., 2004; Lynch et al., 2001). State level studies of social capital and health explore risk for cardiovascular disease (Sundquist, Johansson, Yang, \& Sundquist, 2006), self-rated health (Kawachi, Kennedy, \& Glass, 1999), all-cause mortality (Kawachi, Kennedy, Lochner, \& Prothrow-Stith, 1997), and obesity (Holtgrave 
and Crosby, 2006). Community levels of social capital have been explored within the context of mental health (Harpham, Grant, \& Rodriguez, 2004) and workplace level social capital has gained traction within nursing research (Read, 2013; Sheingold \& Sheingold, 2013; Spence Lachinger, Read, Wilk, \& Finegan, 2014). Investigations involving social capital within community levels such as the neighborhood and workplace currently dominate the health science research literature (Alvarez et al., 2017), leaving a gap in the literature surrounding family level social capital.

Alvarez at al. (2017) discovered a wide range of variability regarding use of "family" within social capital research. Some of the studies defined "family" as a nuclear dyad, while others refer to the family as a broader set of familial connections. Debates continue to explore if unrelated individuals are considered "household" members versus "family" members. Additionally, Widmer et al. (2008) identified that some people consider caregivers as "family." Alvarez et al. (2017) recommend careful consideration in defining family members and household members. While both may share similar values, norms, environments, and resources, Alvarez et al. (2017) warn that this may unintentionally blur the defining borders between family and external influences.

Finally, Alvarez et al. (2017) discovered findings regarding measurement similar to that of Derose and Varda (2009). The literature demonstrates variability within the indicators and measurement modalities across all levels of social capital. Collinearity of family social capital indicators was also identified as a concern as similar indicators were noted to be frequently applied differently across the studies. Alvarez et al. (2017) highlight this concern as family connections could represent a sense of belonging in one study and parental involvement with the child in another study. 


\section{Social Capital, Family social capital, and Measurement}

The literature reveals that social capital is most frequently operationalized by using indicators to assess the key constructs (Alvarez et al., 2017; Alvarez \& Romani, 2017; Kawachi et al., 2010). Many key constructs are shared within the many definitions of social capital including shared norms, trust, reciprocity, a sense of belonging, and accrual of resources that occur as a consequence of membership and participation in social networks (Alvarez et al., 2017). A wide range of depth of analysis and complexity exists among the indicators (Alvarez et al., 2017; Alvarez \& Romani 2017).

The three most common constructs represented within the combined systematic review by Alvarez et al. (2017) and the secondary review include family cohesion, family network, and family support. Family cohesion was most frequently measured via subscales measuring social interaction (activities done as a family), sense of belonging, informal control (parental/community supervision of children), and collective efficacy (perception of well-functioning family). Family support was most frequently measured through analysis of emotional supports, instrumental supports (caregiver/parent availability if child needs help), and presence of family conflict. The final construct of family network was measured by quality of family ties (frequency of contact/emotional closeness) and network approach measures such as extension (members of the family), density (possible amount of connections within the family), and centrality (direct or indirection connections within the family).

The three systematic reviews exploring various facets of social capital and health reveal important gaps in the empirical literature. Social capital today comprises multiple levels, theoretical approaches, dimensions, and measures that complicate its conceptual 
and operational clarity within health science research (Alvarez \& Romani, 2017; Field, 2017; Kawachi et al., 2010). Trends in social capital research reflect a multitude of selfmade social capital scales and an absence of psychometric analysis or conceptual frameworks. Additionally, further research is needed to clarify relationships between social capital and health. Research is sparse investigating the family level of social capital, demonstrating family social capital to be an underutilized variable within health science research. This represents both a challenge and an opportunity for future social capital research. 


\section{CHAPTER THREE}

\section{Introduction}

The concept of social capital has permeated a wide expanse of disciplines across many countries. While it is beyond the scope of this dissertation to provide a detailed review of all of the theoretical and multidisciplinary literature pertaining to social capital, it is pertinent to analyze the concept and address the key multidisciplinary contributions to achieve further parsimony. Notably, a review of the literature demonstrates that the majority of research articles on social capital can be found within the disciplines of sociology, political science, economics, and health (Field, 2017; Kawachi et al., 2010). Key theoretical and multidisciplinary contributions will be discussed, leading into the conceptual framework guiding this research.

\section{Social Capital: Definition, ecological framework, dimensions, approaches}

A synthesis of definitions from Oxford Dictionary.com (n.d.), and The Free Dictionary.com (2018) broadly identifies social capital as resources obtained from membership and participation in social networks. Porta's Dictionary of Epidemiology (2014) further clarifies social capital to include a network-based perspective that conceptualizes social capital in terms of individual attributes and a social cohesion perspective that emphasizes social capital as a group attribute.

\section{Levels of Social Capital: An Ecological Framework}

The structure of social capital is conceptualized within an ecological micro- to macro- framework of socioenvironmental levels extending across individual, family, community (school, workplace, city), local government, and national government. (See Appendix A: Levels and bonds of social capital.) Seminal ecological framework scholar 
Urie Bronfenbrenner (1979) used systems terminology in reference to the variation in relations among children's homes, day care centers, neighborhoods, and (parents) work settings. He also noted that these "macro systems" varied depending on a number of factors including socioeconomic status, ethnicity, religion, belief systems, and other lifestyle factors (Pascoe et al., 2013).

\section{Bonds that connect the Levels of Social Capital}

Additionally, the structural component can be further analyzed to include different types of bonds that connect individuals to various domains across the socioecological framework. These bonds refer to bonding, bridging, and linking (Szreter \& Woolcock, 2004; Woolcock, 2001). Bonding social capital refers to the social ties and resources from strong social networks within horizontal relationships such as family and close friends. This is of relevance to the family level of social capital because family exerts a strong influence within the formative first five years of life for children. Bridging social capital refers to weaker ties that are affiliated with people of varying social networks such as in work or other community level environments. Linking social capital is classified as a type of bridging social capital, however it refers to social connections across hierarchical societal power gradients (Szreter \& Woolcock, 2004).

Social capital researchers exhibit varied preferences in defining the resources obtained via social capital. Some perceive resources as individual gains, whereas others perceive resources as community gains (Kawachi et al, 1997; Lin, 1999; Portes, 1998; Putnam, 2000). Others focus more on the strength of bonds rather than the level along the ecological framework. As social relations impact both individuals and groups, most researchers acknowledge that the two approaches are not mutually exclusive (Lin, 2001; 
Kawachi et al., 2010; Stromgren, Eriksson, Bergman, \& Dellve, 2016). Additionally, many social capital scholars agree that the different conceptualizations of social capital represent complimentary tributaries within social capital research (Field, 2017; Kawachi \& Berkman, 2014; Kawachi et al., 2010). Often, social capital is divided between a cognitive dimension involving perception and a behavioral dimension involving action (Field, 2017).

\section{Social cohesion approach}

The most salient feature of the social cohesion perspective is that it conceptualizes social capital as a group attribute rather than as an individual characteristic. (Alvarez \& Romani, 2017; Kawachi et al., 2010) The social cohesion perspective on social capital (also known as communitarian) focuses upon closeness characteristics within social networks and emphasizes the importance of collective influences upon individuals within the group (Alvarez \& Romani, 2017; Kawachi et al., 2010).

\section{Network approach}

The network school of thought on social capital focuses upon measuring the resources attained by individuals via presence and/or participation in social networks (Kawachi et al., 2010). Emphasis is placed upon individual network position and the resources that are embedded within network ties (Lin, 1999). These network ties are classified according to types of support including emotional, appraisal, instrumental, and informational. Unlike the social cohesion perspective, analysts who adhere to a network approach to social capital perceive the concept as containing both individual and group (or collective) components. (Kawachi et al., 2010). 


\section{Social Capital: Seminal Scholars}

The concept of social capital is hypothesized to have originated in the 1830s; however, a West Virginia state rural school supervisor named L. J. Hanifan is credited with coining the term "social capital" in 1916 (Putnam, 2000). Three seminal scholars are responsible for stimulating academic discourse and research in social capital: Pierre Bourdieu (1986), James Coleman (1990), and Robert Putnam (2000) (Alvarez \& Romani, 2017).

Pierre Bourdieu 1930-2002. Social capital gained the attention of French Sociologist Pierre Bourdieu during his academic exploration of privilege, domination, and social order (Field, 2017). Bourdieu envisioned social capital as a resource accrued by individuals as a result of investments within social networks (Bourdieu, 1986; Woolcock,1998). However, he did not consider social networks and exchanges to be solely philanthropic. Bourdieu argued that social capital was tied to human self-interest and possessed a dark side that could be used to promote marginalization and social elitism (Bourdieu, 1986).

James Coleman 1926-1995. Sociologist James Coleman shared Bourdieu's interest in understanding social order, however, he did not agree with Bourdieu's perception of self-interest as a major motivating factor for human interaction. The central themes featured within Coleman's social theory are that social exchanges permeate human life and that people are connected to resources through each other (Coleman, 1990; Field, 2017). He wanted to gain a sense of what fostered human cooperation, which further fueled his pursuits in generating his social theory. Coleman suggests that “individuals do not act independently, goals are not independently arrived at, [and] 
interests are not wholly selfish" as humans compete for resources and navigate through life (Coleman, 1990, p.301).

Coleman began his exploration of social capital at the intersection of the American educational system and children living in ghettos (Field, 2017). He investigated factors that influence academic outcomes in children from ghettos across America, which led him to consider social capital through a different lens (Coleman \& Hoffer, 1987). He found that social capital was not helpful to only the wealthy and powerful members of society, but also held capacity to supplement vulnerable populations (Coleman, 1990; Field, 2017). While acknowledging that social capital has the potential to both facilitate and restrain from others, Coleman's work emphasizes that social capital holds that productive capacity to foster outcomes that would otherwise be unattainable without membership and interaction within social networks (Coleman, 1990; Woolcock,1998).

Coleman dedicates chapter twelve of his Foundations of Social Theory (1990) text to the discussion of social capital. He conceptualizes social capital as a function of relationships that promotes an exchange of resources that contains two key elements: aspects of social structure and aspects that facilitate action within the structure (Coleman, 1990). He also speaks to the intangible nature of social capital as it exists within the context of personal interaction and relationships (Coleman, 1990). Additionally, Coleman elaborates that social capital should be represented as a variety of functional components that share common characteristics, rather than as a singular entity (Coleman, 1990). Fellow seminal social capital scholar Robert Putnam credits Coleman with integrating social capital into academic discourse (Putnam, 2000). 
Robert Putnam 1941- current. Political Scientist Robert Putnam is the final seminal social capital scholar. Inspired by his research on democracy in Italy and the writings of nineteenth century French author Alexis de Toqueville, Putnam theorized that American democracy was crumbling as a consequence of decreased community engagement (Field, 2017; Putnam, 2000). In Bowling Alone: The collapse and revival of American Community (2000), Putnam champions the value embedded within social networks and speaks to the importance of social capital as a community asset, first in Italy and later in the United States (Field, 2017; Putnam, 2000).

Putnam defines social capital as "the connections among individuals within social networks and the norms of reciprocity and trustworthiness that arise from them" (Putnam, 2000, p.19). While his definition of social capital is similar to that of Bourdieu and Coleman, Putnam aligns with Granovetter (1973) and Woolcock (1998) and delves into the concept by exploring the characteristics of bonds within the structural levels of social capital (Putnam, 2000).

The three seminal social capital scholars stimulated a platform academic discourse involving the structure, function, and science of social capital. Coleman (1990) and Putnam (2000) promote social capital as a positive protective resource; however, they underscore Bourdieu's concerns regarding the role of social capital in power relations and marginalization. The works of Coleman (1990) and Bourdieu (1986) explore social capital as individual and community resources, whereas Putnam's work investigates social capital as resources available to communities and states. Despite their many differences, the seminal scholars of social capital all agree that social capital involves the attainment of resources via interpersonal connections and interactions. All 
three identify norms of reciprocity, recognition, and trust as key factors involving social capital (Bourdieu, 1985; Coleman, 1988; Macinko \& Starfield, 2001; Putnam, 2000). Additionally, the social capital scholarship of Bourdieu, Coleman, and Putnam has fostered international and multidisciplinary investigation.

\section{Multidisciplinary Uses of Social Capital}

Social Capital and Sociology. The first mention of social capital within sociology was in the 1950 s by a group of Canadian sociologists who were investigating social order among arraviste members of aristocratic clubs (Putnam, 2000). Since then, two of the seminal social capital scholars emerged from the field of sociology. Seminal social capital scholars Bourdieu (1986) and Coleman (1990) began to publish their research on social capital in the 1980s. Bourdieu's darker conceptualization of social capital creates an interesting juxtaposition to Coleman's more optimistic perspective. Sociologist Alejandro Portes (1998) examined social capital within the context of the economic sociology of immigration, referring to social capital as the capacity of individuals to obtain scarce resources as a mechanism of group membership or other social structures (Woolcock, 1998). Additionally, key contributions to the network approach of social capital were presented by sociologist Nan Lin (1998, 2001). Lin developed a model of social capital that explored the use of social resources to accomplish goals (Lin, 2001). He was among the first to differentiate between the strength of bonds of different types of social capital and he developed a model of social capital that involved the key tenets of social network membership, social structure, and reciprocity (Lin, 2001; Kawachi et al., 2010). 
Social Capital and Economics. In addition to sociology, the discipline of economics also provides interesting perspectives regarding the concept of social capital. Economists initially conceived social capital within a metaphorical context of investments and returns, similar to that of physical or financial capital (Field, 2017). Contributions to the literature on human capital in the 1960s by Schultz (1961) and Baker helped develop a metric for the value of human labor (Field, 2017). From there, the social capital discourse within the discipline of economics began to shift away from a simplistic transactional perspective (Field, 2017).

Economist Glen Loury (1977) is most famous for his work regarding the economics of discrimination (Woolcock, 1998) and the social legacy of slavery (Putnam, 2000). He challenged economists to consider the concept of social capital as a means to foster the development of human capital in children and adolescents (Coleman, 1990). Loury (1977) defined social capital as the resources that support youth cognitive and social development as obtained through social interactions with families and communities (Coleman, 1990). Seminal social capital scholar James Coleman credits Loury as an important influence in bringing children and families into the social capital conversation. Coleman praises Loury in his Foundations of Social Theory for expanding the concept of social capital to encompass the "family relations [and] community social organizations [that] are useful for the cognitive or social development of a child or young person." (1990, p.300).

Social Capital and Political Science. Building upon the work of previous social capital scholars, political scientist Robert Putnam translated the science of social capital into colloquial context while challenging Americans to re-evaluate the value of social 
networks. Bowling Alone (2000) presents his research and theory about the potential significance of social capital as influence for a disengaged American society. Around the same time of the publication of Bowling Alone, the international health policy world also began to demonstrate a greater interest in the social capital forum.

The social investment and economic gain aspects of social capital began to attract the attention of liberal policymakers from countries around the world including the United States, Canada, Great Britain, and Australia (Fields, 2017). Additionally, The World Bank and the Organization of Economic Cooperation and Development (OECD) began to investigate the relationship between social capital and poverty (Gootaert \& Van Bastelaer, 2002). Initial government focus on social capital focused more so on measurement and monitoring (Field, 2017).

Government considerations surrounding social capital fueled strong reactions from the social capital academic community. Robert Putnam urged policymakers to incorporate social capital and linkage formation into policymaking as a protective mechanism to combat social degradation (Putnam, 2000). Political scientist Francis Fukuyama (2001) cautioned against government interference in generating social capital due to the concern that policies forcing participation would stimulate social erosion rather than foster social cohesion. The Coleman perspective concurred with that of Fukuyama (2001); they were both concerned with the potential damage of government interference within private relationships (Field, 2017).

The changing technology and communication platforms within the United States inspired Political Scientist Barbara Neves (2013) to investigate the relationship between social capital and the Internet. She discovered little evidence that supported a negative 
relationship between online or digital social networking and social dysfunction (Fields, 2017). Her research additionally reveals insufficient evidence linking Internet social network participation with eroding social capital and that the Internet may represent an innovative modality for people to connect (Field, 2017).

Social Capital and Health. Along with his many other contributions in the field of health and medicine, Hippocrates is also credited with acknowledging the important connection among health, the environment, and the human soul (Kritsotakis \& Gamarnikow, 2003). Exploration of the social context of health has contributed knowledge in areas of health care research including but not limited to social determinants of health, adverse childhood experiences, and health inequities and inequalities (Blumenshine et al., 2010; Felitti et al., 1998; Kawachi et al., 1997; Marmot, Shipley, Brunner, \& Hemingway, 2001). Given the converging streams of multidisciplinary research investigating the resources embedded within social networks, increased incidence of chronic health care conditions and concentrated efforts to decrease health care costs, research involving social capital and health science began to flourish around 1996 (Kawachi et al., 2010). The body of literature exploring social capital in health encompasses the disciplines of medicine, public health, and nursing.

International and multidisciplinary evidence supports that high levels of social capital are associated with improved health outcomes including physical health, longer life expectancy, decreased infant mortality, and psychosocial well-being (Carlson \& Chamberlain, 2003; Harpham et al., 2006; Kawachi \& Berkman, 2010; Pascoe et al., 2012; Wang et al., 2016). Additionally, neighborhoods and states with higher levels of social capital had lower rates of overall mortality (Kawachi et al., 1997). Wilkinson 
(1996) proposed social cohesion as an explanation for the link between inequalities (e.g. income inequalities) within societies and poor health (Uphoff et al., 2013). Marmot (2005) has raised similar arguments relating to inequalities in social status.

\section{Social Capital and Nursing: A concept analysis}

The discipline of nursing occupies a unique space within health care to influence social determinants of health. As trusted caregivers and health care providers, nurses operate on the front lines of health care and regularly foster relationships and navigate connections among patients, families, and the system. Ultimately, nursing and the concept of social capital share service as cohesive forces that connect health complex systems.

Social capital today is known to be a multidisciplinary concept that expands across disciplines including sociology, economics, political science, education, and health; the purpose for this concept analysis is to glean data about the current uses, definitions, and discussions surrounding the concept social capital within the discipline of nursing. Avant and Walker (2011) methodology was utilized to describe the concept of social capital within the context of nursing. To capture the current academic discourse, the literature was reviewed via electronic databases utilizing the Boolean search phrases of nursing and social capital. Inclusion criteria included that the article must be in English, publication within in an academic journal, publication time frame from 1997 to 2017, and demonstrate full text availability. Electronic databases represented in this analysis included CINAHL, Pubmed, Psychinfo, Health Source, and Web of Science. JSTOR and ERIC were initially included in the search, however were removed due to a lack of content relevance specific to the nursing discourse of social capital. Results from 
the initial review of the literature yielded a total of 1,031 results. The articles were then further categorized based upon health-related context. Repeat articles were removed. The final analysis included 78 publications.

\section{Results}

Review of the 78 articles involving social capital and nursing yielded a diverse array of publication types, an international presence, and a variety of themes. Types of publications were sorted to reveal 33 quantitative research articles (Table 1), 23 framework-concept focused papers (Table 2), 7 qualitative research articles (Table 3), 5 reviews of the literature (Table 4), 4 papers that explored psychometric properties of instruments (Table 5), 4 evidence-based practice papers (Table 6), and 2 mixed methods research articles (Table 7). The majority of academic publications featuring social capital and nursing over the past 20 years makes up the quantitative research articles and framework/conceptual papers.

\section{Thematic Breakdown by Type of Study}

\section{Quantitative Studies}

Fourteen countries were represented across the 33 quantitative research papers, suggesting an international interest in the intersection of social capital and nursing (Table 1). The quantitative articles were then further analyzed to identify themes within measurement modalities, context, and theoretical underpinnings/definitions of social capital (Table 8). Wide variability in measurement methodology existed within the quantitative research studies involving nursing and social capital. The majority of the studies utilized a combination of indicators, scales, and/or surveys as by proxy measures 
for social capital. Of the instruments that were used to measure social capital, few of them included reports of psychometric properties.

Thematic analysis of the quantitative studies involving social capital and nursing revealed that the most common subject of study over the past 20 years was the nursing workforce. The less common themes included mental health (4), chronic illness (2), pregnancy (3), physical activity (2), families (1), and caregivers (1). The population within the quantitative literature was overwhelmingly adult-focused, with only two studies dedicated to adolescents and one study addressing college students.

Almost all of the quantitative studies involving social capital and nursing identified the work of a seminal social capital scholar. The social capital theory of Robert Putnam provided the theoretical underpinnings for the majority of the quantitative studies, with James Coleman and Pierre Bourdieu also commonly referenced. Interestingly, the studies that involved families and/or children demonstrated proclivity towards Coleman's social capital theory.

\section{Framework/Conceptual Analysis Papers}

The next most prominent category of literature involving social capital and nursing were papers that discussed a new framework or conceptual analysis (Table 2). While these papers do not represent empirical research studies, they do provide insight into the academic discourse surrounding social capital and nursing over the past 20 years. Like the quantitative research studies, analysis of the framework papers revealed an international presence, emphasis on the nursing workforce, adult-centric populations, and popularity of Putnam's social capital theory. Other common themes among the framework papers included social capital within the contexts of public health, rural 
health, child health, and as a construct for nursing. Two of the papers were concept analysis papers; Read (2013) published a concept analysis on workplace social capital and Hseih (2008) published a concept analysis involving social capital within the context of health. There are no concept analysis papers that involve the broad concept of social capital within nursing literature.

\section{Qualitative Studies}

Seven qualitative studies were identified within the literature involving social capital and nursing (Table 3). While all of the qualitative studies involve the adult population, no common theme emerged. Instead, the themes of the seven qualitative studies included parental caregivers of children with special health care needs, adult street drinkers, diasporic women and health care, nurse managers in health care organizations, immigrant men from India in New York City, palliative care caregivers, and a program evaluation for implementing a social capital framework in the primary health care setting. Additionally, there was wide variability among qualitative methods.

\section{Reviews of the Literature}

Of the 78 articles reviewed in this analysis, five of them represented papers that reviewed literature involving social capital and nursing (Table 4). Three of the articles were integrative review articles, one was a systematic review, and the final paper selfidentified as a review of literature. Content analysis of these papers revealed that two of the papers focus on mental health well-being (elders and adolescents). The other three publications reviewed literature on social capital and nursing education, the nursing workforce, and population health. 


\section{Psychometric Analysis}

Results of this concept analysis revealed that nursing research very rarely conducted psychometric analysis nor reported psychometric properties of instruments attempting to capture social capital (Table 5). The four psychometric research studies within this analysis described the youth social capital scale in Greek (Koutra et al., 2012), social capital scale for families of children with special health care needs (Looman, 2006), Arabic social capital scale for families of children with special health care needs (Looman \& Farrag, 2009), and a Persian version of the social capital questionnaire that measured social capital in medical students in Iran (Yaril et al., 2013). All four of the studies utilized exploratory factor analysis, reported Cronbach's alpha values, and featured different populations (Table 5).

\section{Evidence Based Practice}

Nursing has additionally applied evidence-based practice principles to the investigation of social capital and health (Table 6). Four studies from diverse international backgrounds explored social capital as a strategy to enhance access to health care in Spain, differences in social capital among women living in a suburb of Australia, the efficacy of building social capital within a first-time parenting group, and as a means to mitigate suicide (Table 6).

\section{Mixed Methods Studies}

Very few of the articles within this concept analysis utilized mixed methodology research (Table 7). The two studies that did use mixed methods shared an emphasis on policy issues surrounding the utility of social capital as a means to craft social interventions for women's health and mental health in older adults. 


\section{Attributes for Social Capital within a Nursing Context}

The review of nursing literature yielded 49 characteristics that were associated with the concept of social capital (Table 9). Critical attributes included social network, bonds, trust, reciprocity, shared values, solidarity, social norms, safety, participation, communication, and frequency of social interaction. The critical attributes were then classified into a structural dimension or a functional dimension based upon their classification as a perception or a behavior to remain consistent within the social capital literature (Alvarez \& Romani, 2017). Critical attributes within the functional dimension were further grouped into a cognitive domain consisting of attributes reflecting perceptions/what people think (Table 10) and a behavior domain consisting of attributes reflecting what people do (Table 11).

\section{Antecedents and Consequences of social capital}

As suggested by its name, social capital depends upon a network and cannot exist in isolation. The primary antecedent for social capital is membership within a group. Both interaction and non-interaction within a network will affect group dynamics and in turn, influence both the formation and the strength of the concept's critical attributes. The interplay of the network structure and the critical attributes result in consequences, or acquisition of resources.

An exploration of the theoretical origins, historical context, and multidisciplinary applications involving social capital reveal the commonality of social connection. Seminal social capital scholars Bourdieu, Coleman, and Putnam agree that membership and participation within social networks holds the potential to accrue resources. Sociologists, political scientists, economists, public health scholars, physicians, and 
nurses agree that social interaction, group membership, and social investment may represent the capacity to strengthen individuals and communities. Yet, tremendous gaps exist in the literature exploring the relationship between family social capital, health, and measuring all levels of social capital. No previous studies have explored the relationship between family level social capital and pediatric preventative health care utilization.

\section{Conceptual Framework}

Broadly defined as the resources obtained through membership and participation in social networks, the concept of social capital contains rich historical traditions from a wide expanse of scholars and disciplines. Discourse from the three seminal scholars of social capital (Bourdieu, Coleman, and Putnam) propelled social capital into academia, fostering international and multidisciplinary research. Family social capital is defined as resources accrued by children from membership and participation in the family environment (Alvarez et al., 2017; Hsieh, 2008). Informed by a conceptual framework consisting of Coleman's social theory, the discourse surrounding family level social capital, Anderson's Behavioral Model of Health Care Utilization, and the Life Course Health Development Model, this study aims to investigate the association between family social capital, utilization of well-child preventative health care services, and selected demographic variables.

\section{James Coleman and Family Social Capital}

Sociologist and seminal social capital scholar James Coleman (1990) theorizes that social exchanges permeate through human life and that people are connected to resources through each other. Coleman suggests that as humans navigate through life and compete for resources, it is key to remember that "individuals do not act independently, 
goals are not independently arrived at, [and] interests are not wholly selfish" (Coleman, 1990, p.301). He perceives social capital as a function of relationships that promote an exchange of resources with two key elements that include aspects of social structure and aspects that facilitate action within the structure (Coleman, 1990).

Many social capital scholars agree that the family level/scale of social capital represents the "heart" of the social capital concept because individuals exist within family units (Bourdieu 1986; Coleman \& Hoffer, 1987; Coleman, 1990; Fukuyama, 2001 Putnam, 2000), however Coleman is credited with bringing family into the social capital discourse. He defined the main function of family social capital as sharing parent human capital with their children as measured by parent physical presence and parent attention towards a child (Coleman, 1990). Coleman further explores the concept of family social capital within the context of education and presents three indicators: parent child ratio, frequency of which the child discusses life experiences or personal topics with parents, and mother's educational expectations for the child. (Coleman, 1988). He subscribes to the social cohesion approach on family level social capital because it emphasizes that family membership, family participation, and parent/caregiver-child relationships contribute towards a bank of resources for children (Coleman, 1990). He also argues that the individual "network" of a child is already implicit within the family structure (Coleman, 1990), therefore the focal point for the accumulation of child resources is family interaction.

\section{Critiques of Coleman's Conceptualization of Family Social Capital}

Coleman's seminal work stimulated conversations surrounding the definition, operationalization, and measurement of family social capital. However, critiques of 
Coleman's work represent important contributions in advancing the science of social capital. Research from the Australian Institute of Family Studies challenged Coleman's measures of family social capital to be biased towards involving only the structural components (Alvarez et al., 2017; Stone, 2001). For example, measuring the frequency of family conversations but not analyzing the quality of the discussions. Additionally, Coleman's conceptualization of family social capital assumes children to be passive elements within the family structure (Alvarez et al., 2017). Morrow (2004) advocates for an active role for children within the concept of family social capital as children hold the capacity to engage in the process of creating and negotiating social capital resources within their family environment. Finally, Coleman's family social capital does not include sociodemographic variables. Evidence presented within the systematic review by Alvarez et al (2017) demonstrates that personal characteristics, caregiver values, and caregiver behaviors impact group values and norms.

While there is no current uniform instrument or operational definition for social capital, trends extracted from a review of the empirical literature and seminal social capital theory inform the framework and variable selection for this study. All three seminal social capital scholars agree that social capital involves trust, norms of reciprocity, social interaction (Bourdieu, 1985; Coleman, 1990; Macinko \& Starfield, 2001; Putnam, 2000). Additional distinctions have been made among different socioecological levels of social capital and functional dimensions of social capital (Alvarez et al., 2017; Alvarez \& Romani, 2017). The functional dimensions within family level social capital are divided into cognitive (what parents perceive) and behavioral (what families do together) dimensions (Alvarez \& Romani, 2017). 


\section{Anderson's Behavioral Model of Health Care Utilization}

Access to health care represents a complex and multi-dimensional phenomenon (Komniski, 2014). Anderson's behavioral model of health care utilization provides a framework that defines the dimensions associated with access to health care by way of four macro-variable categories including predisposing factors, access factors, health behaviors, and health care utilization. Each of these categories represents multiple variables within them as driven by the larger model. Family social capital represents an enabling factor within the access category. (Komniski, 2014). The selection of the sociodemographic characteristics within this study were informed by this model and additionally supported by the literature.

\section{Life Course Health Development Theory}

The asset-based, multidisciplinary, and relational aspects of social capital align well within the tenets of the Life Course Health Development theory (LCHD). Conceived by an amalgam of research from behavioral, social, and biological sciences; the LCHD theory defines health development as a complex and non-linear process that results from a host of multilevel, multidimensional, multidisciplinary, and multidirectional interactions (Halfon, Larson, et al., 2014). The LCHD theory posits that health disparities originating in childhood perpetuate poor health trajectories across the life span, while also proposing that exposures to positive protective mechanisms hold the capacity to mitigate negative health trajectories (Halfon, 2016; Levy \& Sidel, 2013; Rosenbaum \& Blum, 2015; Shonkoff et al., 2012). Key tenets of the Life Course Health Development Model can be accessed at http://www.lcrn.net/wpcontent/uploads/2015/05/LCHD_DiagramPrinciplesv2_PPTuse.png. 
While the LCHD theory consists of six core tenets involving health development, the fourth tenet is relevant to social capital: "Health development is sensitive to the timing and social structuring of environmental exposures and experience.” In conclusion, family social capital may represent a potential positive protective resource to strengthen the social scaffolding for child health. Childhood represents a sensitive and critical time period, with child health strongly influenced by family structure, family function, family environment, and access to health care services (Halfon, 2016; Halfon, Larson, et al., 2014; Kominski, 2014). (See Appendix B.) 


\section{CHAPTER FOUR}

\section{Introduction}

The purpose of this study was to examine the relationship between family and child sociodemographic characteristics, family culture characteristics, family social capital, and regular utilization of well-child health care services among healthy children aged 0-5 in California within the National Survey of Children's Health (NSCH) 2016. Chapter four of this dissertation presents the study design and results as organized by the specific aims of the research.

\section{Study Design}

The investigator conducted a secondary analysis of data selected from the California subset of data from the 2016 National Survey of Children's Health (NSCH) to examine the relationship between family social capital and regular utilization of preventative child health care services. Specifically, data were analyzed from a representative sample of cases of healthy children aged 0-5 years old from the California data within the National 2016 NSCH data set.

\section{The 2016 National Survey of Children's Health (NSCH)}

The 2016 National Survey of Children's Health (NSCH) is a cross-sectional survey conducted by the United States Census Bureau from June 10, 2016 to February 10, 2017 and sponsored by the Health Resources and Services Administration's (HRSA), Maternal and Child Health Bureau (MCHB), and the Associate Director for Demographic Programs on behalf of the United States Department of Health and Human Services (HHS)(United States Census Bureau [USCB], Associate Director of Demographic Programs, National Survey of Children's Health, 2017). Data collection for the original 
NSCH began in 2003 with the purpose of collecting state and national level indicators involving child health and health care in the United States (Child and Adolescent Health Measurement Initiative, 2018 NSCH, 2013; USCB et al., 2017). In order to capture a better understanding of children with special health care needs in the United States, the MCHB combined the National Survey of Children with Special Health Care Needs (NSCSHCN) with the NSCH in 2001, 2005-2006, 2009-2010, and 2016.

While the goals of the $2016 \mathrm{NSCH}$ remain consistent with the overall goals of previous versions of the $\mathrm{NSCH}$, the sampling frame has transformed over time. Insight from previous iterations of the NSCH helped inform the redesign for the $2016 \mathrm{NSCH}$ sampling frame. Further information regarding the NSCH prior to the $2016 \mathrm{NSCH}$ redesign can be accessed at http://childhealthdata.org/learn/NSCH (USCB et al., 2017). The NSCH 2016 combines the NSCH with the NC-CSHCN into a singular survey with the continued purpose of gaining a clearer understanding of the health, health care, and social factors involving children and families in the United States (USCB et al., 2017).

National-Level Data. The sample for the 2016 NSCH was created by random selection of 364,150 residences from the United States Census Master Address File. An indicator developed by the Census Bureau's Center for Administrative Records Research and Applications (CARRA) was then applied to separate the addresses into households with children under 18 years of age (stratum 1) or without children (stratum 2).

Residences with children (stratum 1) were oversampled at a 5:1 ratio in comparison to those without children (stratum 2) (USCB et al., 2017).

The sample of addresses that identified children within the household were mailed an invitation to participate and the opportunity to select either a web-based or paper- 
based response modality for completing the 2016 NSCH (USCB et al., 2017). The webbased survey instrument combined the screener and detailed topical questionnaire into one instrument, whereas the paper and pencil interviewing (PAPI) screening instrument was divided into a separately mailed screener and detailed topical questionnaire. The screener questionnaire confirmed the presence of an actual address, identified the presence of children living within that household, and included questions to determine if any of the children could be classified as a child with special health care needs (CSHCN). If multiple children resided within a single household, one child was randomly selected for the detailed topical questionnaire. A copy of the screener questionnaire can be accessed at https://mchb.hrsa.gov/sites/default/mchb/Data/householdscreener.pdf. Data from the initial screener questionnaire categorized the sample for the detailed topical questionnaires $(\mathrm{T})$ by grouping the children into age defined groups: $\mathrm{T} 1$ for children aged 0-5 years old, T2 for children aged 6-11 years old, and T3 for children aged 12-17 years old. Copies of the detailed age-specific topical questionnaires can be accessed at https://mchb.hrsa.gov/sites/default/files/mchb/Data/nschchildren0-5.pdf, https://mchb.hrsa.gov/sites/default/files/mchb/Data/nschchildren6-11.pdf, and https://mchb.hrsa.gov/sites/default/files/mchb/Data/nschchildren12-17.pdf. All questionnaires were available in English and Spanish.

State-Level Data. State-level sample addresses were generated based upon the number of households per strata per state. The state-level samples were created to yield an approximately equal number of completed questionnaires for children with and without special health care needs per state (USCB et al., 2017). As older children have a higher likelihood of reporting special health care needs, children within an age range of 
0- 5 years old (T1) were oversampled to offset the potential age bias. Data obtained from the web-based instrument were subsampled upon completion of the screener survey, whereas data obtained from the paper instrument involved selection through review of the mailed in responses to the paper screener questionnaire (USCB et al., 2017).

Respondents. Of the 139,923 addresses across the United States that were screened for children living in the household, a total of 68,962 residences reported the presence of children and 70,962 reported no children. The initial screener survey was completed by 67,047 household respondents including parents, guardians, and primary caregivers with health and health-related knowledge regarding the selected child. Of the national sample of households with children, 50,212 age-specific detailed topical questionnaires were completed by a pool of respondents including $63 \%$ mothers (adoptive, biological, foster, or step), 30\% fathers (adoptive, biological, foster, or step), and $7 \%$ other guardians or relatives. A total of $40,493(80.6 \%)$ of the respondents utilized the web-based instrument and the remaining 9,719 (19.4\%) respondents utilized the PAPI instrument (USCB et al., 2017).

Weighting. Use of weighting within the $2016 \mathrm{NSCH}$ yields representative national and state level samples of non-institutionalized children aged 0 to 17 years old with confirmed residence locations. Weighting within the $2016 \mathrm{NSCH}$ data does not generalize to parents, caregivers, or health care providers (USCB et al., 2017). The process of case weighting for this data involved the following: 1. adjustments for lack of response to screener questionnaire $(\mathrm{S}), 2$. Application of a sample balancing raking procedure to match eligible children from $\mathrm{S}$ to population controls, 3. application of a subsampling within-household factor to S cases, 4. Adjustments for lack of response to 
detailed topical questionnaire $(\mathrm{T})$, and application of a sample balancing raking procedure that matched the estimated sample demographics to demographic controls (USCB et al., 2017). Weighting schemes were utilized for both the screener questionnaire data (S) and the detailed topical questionnaire data (T) in the 2016 NSCH (USCB et al., 2017). Raking for S cases involved State by Child's Race by Child's Ethnicity and State by Child's Sex by Child's Age Group (USCB et al., 2017). Raking for T cases was performed using 6 dimensions of interest including State by Household Poverty Ratio, State by Household Size, State by Respondent's Education, State by Selected Child's Race by CSHCN Status, State by Selected Child's Ethnicity by CSHCN Status, and National Selected by Child's Age. Data from the 2015 American Community Survey were the raking source for independent population controls (USCB et al., 2017).

Missing values. Flags are incorporated into the public data files of the 2016 $\mathrm{NCSH}$ to indicate missed and imputed values. Pertinent percentages of missing values within the data include: flag for child's sex (C_SEX_IF) $0.21 \%$, flags for all child race variables(C_RACE_R_IF) $0.7 \%$, flag for child's Hispanic origin (C_HISPANIC_R_IF) 0.99\%, flag for selected child's sex (SC_SEX_IF) $0.1 \%$, flag for imputed child race variables (SC_RACE_R_IF) $0.32 \%$, flag for selected child's Hispanic origin (SC_HISPANIC_R_IF) $0.32 \%$, flag for primary adult educational attainment (A1_GRADE_IF) 3.04\%, flag for size of household (HHSIZE_IF) 3.67\%, and flag for poverty ratio (FPL_IF) $18.56 \%$ (USCB et al., 2017). The two most underreported values from the national data are poverty ratio (18.56\%) and size of household (3.67\%).

Data access plan. Data from the $2016 \mathrm{NSCH}$ are available for public use via https://www.census.gov/programs-surveys/nsch/data/nsch2016.html. Information 
involving the codebook and variable lists can be accessed from

https://www.census.gov/programs-surveys/nsch/technical-

documentation/codebooks.html. Guidelines for data use are clearly articulated per the USCB documentation; users of the public data files of the $2016 \mathrm{NSCH}$ may only use the data for the purpose of statistical analysis and reporting, are prohibited from violating confidentiality involving the data, and may not link this data set to any other data set that includes individual case identifiers (USCB, 2017).

\section{Protection of Human Subjects}

This research was reviewed prior to initiation of this study and determined to be of exempt status by the University of San Diego Institutional Review Board (IRB) (Appendix C). The 2016 NSCH was conducted by the USCB for the HHS (USCB et al., 2017). The HHS has permission to gather information on the health and wellbeing of children in the United States under Title 42 of the U.S.C. Section 701(a)(2). Additionally, Title 13 of the United States Code, Section 8(b) grants the USCB the authority to conduct data collection on behalf of other agencies. Confidentiality is mandated via 13 U.S.C. Section 9. Both the USCB and the HRSA MCHB have removed direct identifiers from the data; respondent privacy is additionally protected as it is not feasible to link the data from the screener questionnaire file and the detailed topical questionnaire. Further information regarding the UCSB's process for privacy and confidentiality can be accessed by calling the Policy Coordination Office at 1-800-923-8282 (USCB et al., 2017). 


\section{Funding for the NSCH 2016}

Primary funding for the NSCH 2016 was supported via the United States Department of Health and Human Services (HHS), and the Health Resources and Services Administration's (HRSA) Maternal and Child Health Bureau (MCHB). Additional funding for specific inquiries within the NSCH 2016 were provided by the Centers for Disease Control and Prevention (CDC), National Center on Birth Defects and Developmental Disabilities (NCBDDD), and the United States Department of Agriculture (USDA) Food and Nutrition Service (UCSB et al., 2017).

\section{Sampling Procedures, Inclusion Criteria, Exclusion Criteria}

California-specific cases were separated from national-level 2016 NSCH data via content from the detailed topical questionnaire data file. The sample was then further adjusted to include all children within the age range of 0 to 5 years old (T1 detailed topical questionnaire) who reside in households in which English or Spanish is the primary language at home. English and Spanish speaking families were selected for inclusion in this study as they represent the most common languages spoken in California. Additionally, all questionnaires within the $2016 \mathrm{NSCH}$ were distributed in both languages (USCB et al., 2017)

\section{Variables}

Variable selection for this study was informed by seminal social capital scholar James Coleman's social capital theory (1990), Anderson's Behavioral Model of Health Care Utilization (Kominski, 2014) and a review of pertinent multidisciplinary literature. After the dependent and independent variables for the study were selected, they were matched with appropriate variables within the $2016 \mathrm{NSCH}$ (Table 12). 
Preventative health care utilization. The Bright Futures recommendations for the amount of well-child health maintenance visits varies per age of the child (American Academy of Pediatrics, 2017b). Variable K4Q20R from the T1 detailed topical questionnaire measured the number of times the child visited a health care professional for the purpose of a preventative check-up over the past year. A preventative check-up was defined as a health care visit with a physician or other health care provider for when a child is not sick that included an annual physical, well-child check, or sports physical. The dependent variable of utilization of preventative health care services was measured via trichotomous ordinal scores that measured frequency of child health maintenance visits as no visits, one visit, or two or more visits to a physician or other health care provider over the past 12 months. Responses were coded in the T1 questionnaire as 1 for no visits, 2 for one visit, and 3 for greater than or equal to two visits.

Family Social Capital. The independent variable of family social capital was defined as the resources accrued via membership and participation within a family social network. Family social capital was further operationalized to include aspects of family structure and aspects that facilitate action within the family structure. These aspects that facilitate action within the family structure were divided into a cognitive domain consisting of four categorical variables and a behavioral domain consisting of three continuous variables and one categorical variable. Each of the eight family social capital variables were derived from recurrent use in the literature and paired to match with specific indicators within the $2016 \mathrm{NSCH}$. Categorical cognitive domain family social capital variables included meeting the day-to-day demands of caring for a child, perceived safety in community, presence of emotional support in raising the child, and 
frequency of the family working together to solve problems. Categorical behavioral domain family social capital variables included days per week that the family eats meals together, days per week reading with child, days per week telling stories or singing songs with the child, and frequency of enforced regular bedtime on weeknights.

Sociodemographic Characteristics. Child and family demographic variables included the age of the child, child designation as male or female, number of family members living in the household, highest level of education among all adults in the household, parent marital status, if the primary caregiver received support from a place of worship/religious leader, and type of health care insurance. Demographic variables capturing culture included child race/ethnicity, if the child was born in the United States, if the adult caregiver respondent was born in the United States, household generational status, and primary household language.

\section{Data preparation and analysis plan}

Statistical analysis was performed using SAS software version 9.3 and IBM SPSS software version 24 . The public access data file for the $2016 \mathrm{NSCH}$ was downloaded using SAS software. California cases were identified via the federal information processing standard code (FIPS) of 6 and sorted into a California subset that contained a total 942 unweighted cases. After the unweighted cases were categorized by age of the child, the final sample of the California subset of the $2016 \mathrm{NSCH}$ consisted of 257 children aged 0-5 years old. This was then imported into SPSS for analyses.

Preliminary analysis of the dataset revealed the need for two augmentations. As the 2016 NSCH initially measured child race and Hispanic origin of the child as two separate variables, variables SC_HISPANIC_R and SC_RACE_R were combined to 
create one unified child race variable named race_eth. Additionally, the family social capital variables within the $2016 \mathrm{NSCH}$ featured inconsistent rank order scoring. In order to maintain consistency of ordinal ranking across all of the family social capital variables, variables with inverse ordinal ranking were recoded. Family social capital variables that underwent the recoding procedure included how well the caregiver is meeting demands raising children, perceived neighborhood safety, presence of day-to-day emotional support for the caregiver in raising the child, likelihood of the family working together to solve problems, and frequency that the child has a regular bedtime on weeknights.

Descriptive statistics were conducted for all child and family sociodemographic characteristics, family culture characteristics, family social capital variables, and preventative health care utilization. Bivariate associations were calculated between sociodemographic characteristics and utilization of preventative health care services (Pearson Chi Square Test of Independence), family social capital variables (Spearman's Rho correlation coefficient), and family social capital variables and utilization of preventative health care services (Spearman's Rho correlation coefficient). Relationships between preventative health care utilization, family social capital variables, and sociodemographic characteristics were then assessed to determine if the data met the assumptions for ordinal regression. In conclusion, ordinal regression modeling was not performed due to a lack of significant relationships between preventative health care utilization, family social capital variables, and sociodemographic variables.

Specific Aim 1. Define and analyze the concept of social capital and the extent of the nursing literature surrounding this topic. 
A concept analysis was conducted to define and explore the concept of social capital within nursing literature. The concept analysis is embedded into chapter three. Results provided conceptual clarity, identified the critical attributes of social capital as derived from current nursing discourse, and informed the conceptual framework for this study.

Specific Aim 2. Describe demographic characteristics including child age, child sex, child race, family culture, who lives at home, primary caregiver education level, parent marital status, type of health insurance, family social capital, and utilization of well-child health care services (defined as meeting or not meeting the recommended guidelines for well-child health visits over the past year as gleaned from the survey) in all cases within the California subset of the 2016 National Survey of Children's Health.

Child and family sociodemographic characteristics. Descriptive analysis of child and family demographic characteristics within the sample explored family structure, child age, child gender, difficulty in covering basic necessities, highest level of adult education in the household, frequency of seeking support from places of worship/religious leaders, and status/type of health insurance (Table 13). Family structure consisted of married couples $(87.1 \%$ reported married parental relationship status and $12.9 \%$ reported unmarried parental relationship status), with three to four family members living at home ( $75 \%$ of the total sample), and at least one child aged $0-5$ years old living in the household. Child gender was fairly equally distributed among cases, with $43.6 \%$ of the children identified as female and $56.4 \%$ identified as male. Child age was equally distributed among cases with children aged 2 to 5 years of age, however fewer 
younger children were represented in the sample as compared with the frequency of older children. Of the entire sample, $10.1 \%$ of the cases were less than one year old and $13.2 \%$ were one year old. The remaining distribution of child ages within the sample consisted of 2-year-olds (17.5\%), three-year-olds (18.7\%), four-year-olds (21.8\%), and five-yearolds (18.7\%). The majority of the children in the sample were 4 years of age.

Among the cases with children aged 0-5 years of age within the unweighted California subset of the $2016 \mathrm{NSCH}$, caregivers reported doing well in providing basic needs for their families, were educated, did not frequently look to places of worship or religious leaders for emotional support, and possessed health insurance. The majority of the sample (60\%) reported no difficulty in obtaining basic family necessities such as food or housing. Additionally, $24.1 \%$ reported rare difficulty, $11.7 \%$ reported some difficulty, and $3.1 \%$ reported frequent difficulty in covering family basic needs. Many of the families $(89.5 \%)$ reported that an adult family member living in the household attended college and many had achieved a college degree or higher (72.5\%). Additionally, the sample featured a high prevalence of cases with health insurance (Figure 2). Families were insured by private insurance (74.3\%), public insurance (19.8\%), mixed public and private insurance (3\%), and 3.5\% did not have health insurance. Approximately $1.2 \%$ of the respondents reported a "not specified" insurance status.

Family culture characteristics. A combination of child, parent, and household characteristics were analyzed as a representation of family culture within the sample (Table 14). The majority of children in the unweighted cases of children aged 0 to 5 years old within the California subset of the 2016 NSCH sample were born in the United States 
$(96.1 \%)$. Of the adult caregiver respondents, $63.2 \%$ were born in the United States and $36.8 \%$ were not born in the United States.

The 2016 NSCH defined parental nativity per the United States Census definition of generational status within the household: first generation households were defined as both child and adults in the household were not born in the United States (UCSB et al. 2017). Second generation households were defined as at least one parent in the household was born abroad, one parent was born in the United States, and the child was born either in the United States or abroad (UCSB et al. 2017). Third generation or higher households were defined as all parents in the household were born in the United States with the birthplace of the child as being irrelevant to the classification (UCSB et al. 2017).

Descriptive analysis demonstrated that approximately $50.4 \%$ of the total sample consisted of third generation households. Among the remaining cases, $38.2 \%$ were second generation households and 3.9\% were first generation households. Additionally, $7.5 \%$ of the sample reported that they did not identify with any of the definitions for generational status as used in the $2016 \mathrm{NSCH}$.

English was the most common household language (79.3\%) within the sample, 9.6\% of households predominantly spoke Spanish and $11.2 \%$ of households primarily spoke another language at home. Child race affiliation within the sample included NonHispanic White (33.9\%), Hispanic (28.4\%) Asian (21.4\%), some other race (13.6\%), and Non-Hispanic Black (2.7\%).

Independent Variable: Family Social Capital. Family social capital was operationalized within this study with variables from the $2016 \mathrm{NSCH}$ that best matched to the critical attributes of social capital. Four cognitive family social capital variables 
captured family perceptions and included how well the caregiver is dealing with the demands of raising a child, child safety in the neighborhood, if the caregiver has someone to turn to for emotional support in raising the child, and if the family works together to solve problems. Four behavioral family social capital variables captured family behaviors and included how many days per week the family spends eating meals together, how many days per week the family spends reading to the child, how many days per week the family spends singing songs/telling stories with the child, and how often the child goes to bed at the same time per weeknight.

Frequencies and percentages were calculated from the nominal and ordinal categorical data to describe the characteristics within the cognitive (Table 15a) and behavioral (Table 15b) domains of family social capital. Results reflect that caregivers reported handling the demands or raising children either very well $(62.8 \%)$ or well (36\%), children were either definitely safe $(59 \%)$ or safe $(32.3 \%)$ in their neighborhood environments, and that $76 \%$ of the adult caregiver respondents had someone to turn to for emotional support in raising children. Additionally, 55.8\% of the respondents reported families worked together to solve problems all of the time and $36.7 \%$ reported families worked together to solve problems most of the time.

Most of the cases in the sample engaged in activities such as eating, reading, singing, and storytelling with children. Approximately $50 \%$ of the cases featured families that ate together every day, whereas $31 \%$ ate together four to six times per week. Daily singing and storytelling was also a common occurrence, with $51.5 \%$ engaging in these behaviors with their child every day and $17.9 \%$ engaging in these behaviors with their child four to six days per week. Additionally, parents reported reading to their children on 
a daily basis (41\%), four to six times per week (21.5\%), and one to three times per week $(32.2 \%)$. Daily reading was less frequent than daily singing or storytelling. The majority of cases in the sample demonstrated that children had weeknight bedtimes at the same time every night $(37.8 \%)$ or usually at the same time every night $(52.6 \%)$.

Dependent variable: Preventative health care utilization. Along with the majority of cases in the sample having access to health care via possession of health insurance, descriptive analysis revealed that most of the children in the sample attended preventative health care visits over the past 12 months (Table 16a). Cases were grouped for analysis per child age because the amount of recommended preventative health care well-child visits per year varies by age (Table 16b). Of the sample, 9.7\% underutilized pediatric preventative health care services (Table 16c). A total of six cases reported children that did not attend any preventative health care visits within the designated survey time frame of 12 months.

Specific Aim 3. Analyze the associations between child and family demographic characteristics, family culture characteristics, family social capital, and utilization of well-child health care services within the study population.

Bivariate associations were investigated between sociodemographic characteristics with utilization of preventative health care services, family social capital variables, and family social capital variables with utilization of preventative health care services. Nonparametric methods for analysis were selected as the data did not meet the assumptions for parametric data. 


\section{Associations between sociodemographic characteristics and preventative}

health care utilization. Pearson's chi square test of independence was utilized to determine the relationship between preventative health care utilization and sociodemographic characteristics. Relationships were interpreted via a Pearson chi square value or a Fisher's exact probability value. For cells that demonstrated frequencies of less than 5, Fisher's exact probability value was reported instead of the Pearson's chi square value (Pallant, 2016). Results were reported within the context of a non-directional hypothesis and were considered statistically significant at $p<0.05$. Exact significance was reported rather than asymptotic significance due to the small sample size of 257 cases (Polit \& Beck, 2017).

The index for approximating the magnitude of effect was selected based upon the characteristics of the contingency table involving the dependent variable and sociodemographic characteristics. As the dependent variable was trichotomous and thereby created contingency tables greater than $2 \times 2$, Cramer's V was selected as the index to describe the magnitude of the effect (Polit \& Beck, 2017). Cramer's V and values were interpreted per Cohen's criteria for small effect size (0.1), medium effect size (0.3), or large effect size (0.5) (Cohen, 1988).

After a chi-square test of independence was conducted between the dependent variable of preventative health care utilization and all of the sociodemographic variables (Table 17a), statistically significant associations were identified between preventative health care utilization and child age (chi-square $=61.9, p<0.005$, Cramer's V $=.364$ ) and child race/ethnicity (fisher's exact probability $=15.8, p=0.024$, Cramer's $\mathrm{V}=0.053$ ). This suggests that child age and race/ethnicity both impact utilization of well-child 
preventative health care services within this sample. No other sociodemographic variables were significantly related to preventative health care utilization.

Correlations between family social capital variables. Correlations between family social capital variables were calculated using Spearman's Rank Order Rho (rho) as a means to check for multicollinearity between the variables (Table 17b). Cohen's criteria were used to analyze strength of the association with a small correlation indicated by a rho value of 0.10 to 0.29 , a medium correlation indicated by a rho value of 0.30 0.49 , and a large correlation indicated by a rho value of $0.50-1.0$ (Cohen, 1988). Results were considered to be statistically significant at $p<0.05$ and $p<0.01$ and were reported within the context of a non-directional hypothesis (two-tailed).

Correlations within the cognitive domain of family social capital. Variables within the cognitive domain of family social capital were operationalized in this study through categorical data that measured caregiver perceptions of critical attributes of social capital. Ordinal ranking was utilized to measure how well the caregiver perceived they are doing in handling the day-to-day demands of raising children, safety in the neighborhood, receipt of emotional support in caring for children, and the likelihood of the family working together to solve problems. As the rank order scores for these variables were inversely proportionate to the strength of the perception (a score of 1 represented doing very well, whereas a score of 4 represented doing very poorly), the scores were re-coded in SPSS to reflect higher scores with an increased perception of doing well. Strength of association was determined per Cohen's criteria: small $r=.10$ .29 , medium $r=.30-.49$, and large $r=.50-1.0$ (Cohen, 1988). 
Analysis revealed three small positive correlations within the cognitive domain of family social capital. How well caregivers handled the demands of raising children was positively correlated to child safety in neighborhood (rho $=0.167, p<0.01)$ and how often families worked together to face problems. (rho 0.215, $p<0.01$ ). Additionally, a small positive correlation was found between the caregivers who received emotional support in caring for children and families that worked together to solve problems (rho = $.144, p<0.05)$.

\section{Correlations within the behavioral domain of family social capital. Ordinal}

ranking was utilized to measure behavioral family social capital characteristics including the days per week that the family ate meals together, read to the child, frequency of singing/storytelling with the child, and how often the child goes to bed at the same time. Days per week eating meals, reading, and singing songs/telling stories with the child were allocated higher scores to represent a greater amount of activity. Scores of one represented that the family never engaged in the activity, whereas a score of four represented that the activity was a daily behavior. The variable that measured the prevalence of regular bedtime was re-coded as to remain consistent with the rank order of the other characteristics within the behavioral domain of family social capital.

Results (Table 17b) revealed small positive correlations between the days per weeknight that child went to bed at a regular time and the days per week that the family ate meals together $($ rho $=.196, p<0.01)$ as well as a regular bedtime and days per week singing songs or telling stories with the child (rho $=.139, p<0.05)$. Days per week that the family ate meals together demonstrated a small positive correlation with days per week singing songs or telling stories with the child $($ rho $=.182, p<0.01)$ and days per 
week reading to the child $($ rho $=.131, p<0.05)$. A medium positive correlation existed between the days per week reading to the child and frequency of telling stories/singing songs to the child (rho .571, $p<0.01$ ).

\section{Correlations between the cognitive and behavioral domains of family social}

capital. After calculating associations between the variables within each separate domain of family social capital, analysis was continued to investigate relationships between the cognitive and behavioral domains of family social capital. Results revealed seven small positive correlations between variables (Table 17b) including families that work together to solve problems and days per week that the family eats meals together $($ rho $=.168, p<0.01)$, families that work together to solve problems and days per week spent singing songs and telling stories with child (rho $=.179, p<0.01$ ), caregivers receiving emotional support in raising children and days per week singing songs or telling stories with the child (rho $=.292, p<0.01)$, caregivers receiving emotional support in raising children and days per week reading the child (rho $=.240, p<0.01)$, meeting the demands of raising children and days per week telling stories or singing to the child (rho .141, $p<0.05$ ), meeting the demands of raising children and number of weeknights that child has a regular bedtime (rho .241, $p<0.01$ ), and perceived child safety in the neighborhood and days per week reading the child (rho $=.165, p<0.01$ ).

Specific Aim 4. Examine the relationship of family social capital and child preventive health care utilization while controlling for statistically significant demographic characteristics in the study population. 
Relationships between preventative health care utilization, family social capital variables, and sociodemographic characteristics were analyzed to determine if the data met the assumptions for ordinal regression modeling. Results of bivariate analysis demonstrated no statistically significant relationships between the independent variable and dependent variable (Table 17c). Therefore, it was not feasible to test the hypothesis that there will continue to be a statistically significant association between family social capital and use of child preventative health care services when controlling for demographic characteristics due to the lack of significant relationships among the study variables. 


\section{CHAPTER FIVE}

\section{Introduction}

A secondary analysis of the $2016 \mathrm{NSCH}$ was conducted to explore the relationship between utilization of pediatric preventative health care services, family social capital, sociodemographic characteristics, and family culture characteristics. Statistically significant associations were discovered between preventative health care utilization and child age (chi-square $=61.9, p<0.005$, Cramer's V $=.364$ ) and child race/ethnicity (fisher's exact probability $=15.8, p=0.024$, Cramer's $V=0.053$ ). Many of the family social capital variables demonstrated small positive correlations with each other, however none of the family social capital variables demonstrated statistically significant relationships with the dependent variable of preventative health care utilization. Ordinal regression analysis was not conducted due to a lack of significant associations between the dependent and independent research variables. The final chapter of this dissertation will discuss the results of the study, address limitations of the research, explore the findings within the context of current relevant literature, provide recommendations for future research, and describe implications for nursing and public health.

The lack of statistically significance results in this study do not equate to meaningless results. As failing to reject a null hypothesis may be caused by a variety of reasons, non-significant results represent inconclusive rather than false results (Polit \& Beck, 2017). Factors that contribute towards retaining a false null hypothesis include type of study design, homogeneity of the sample, insufficient sample size (low power), 
unreliable measures, poor internal validity, or inappropriate statistical procedures (Polit \& Beck, 2017).

\section{Commentary regarding secondary analysis of preexisting data}

Research studies involving secondary analysis of a preexisting dataset has gained traction in health research over recent years. As the data has already been collected, this can be a time- and cost- effective method for conducting research. Preexisting datasets often include large amounts of data that have a greater likelihood of generating a representative sample, allow for the inclusion of more variables in a study, and can identify trends in the data (Polit \& Beck, 2017). Despite these advantages, secondary data analysis has important limitations.

Results of secondary analyses often fail to demonstrate statistically significant findings (Rudestam \& Newton, 2015). This is not a reflection of faulty research, but flawed design. Often, datasets selected for a secondary analysis not created to match the research question of the secondary analysis research study (Polit \& Beck, 2017). Investigators using secondary analysis often do not have control over the types of variables selected for the dataset, measurement of the variables, or the process by which data is collected and recorded. If the variables of interest for a secondary analysis study do not match up conceptually with the variables within the preexisting dataset, investigators may engage in post hoc attempts to construct measures from preexisting data (Polit \& Beck, 2017). Conversely, the large amount of cases and the fact that the types of included variables are not directly determined by the researcher may lend to findings that are statistically significant, but lacking in clinical relevance (Schlmoer \& Copp, 2014). These disconnections represent important considerations regarding 
methodology, reliability, validity, and interpretation of results derived from secondary analysis research studies (Waltz, Strickland, \& Lenz, 2017).

\section{The 2016 National Survey of Children's Health: A Critical Analysis}

The 2016 NSCH is a cross-sectional survey designed to collect information across a 12-month time span about the health and health care of children in the United States (UCSB et al., 2017). As cross-sectional data cannot make inferences about causality or change over time, this represents an important limitation within the design of the study.

Data collection from previous iterations of the NSCH are very different than that of the 2016 NSCH. For example, the 2003, 2007, and 2012 NSCH were administered via the CDC's National Immunization Survey (NIS). List-assisted random-digit-dial (RDD) was utilized for both telephone landlines and cell phone numbers (CDC \&National Center for Health Statistics, 2013). Cell phone numbers were initially included if respondents did not have a landline or reported that they were unlikely to use their landline, however this was augmented after April 2011 to a "take all" approach (NSCH, 2013; CDC \& National Center for Health Statistics, 2013). Respondents were then selected based upon confirmation of a child residing in the household at the time of the interview. After eligibility was determined and a target child was identified, an attempt was initiated to conduct a full interview with the respondent (NSCH, 2013). This is a very different from the data collection process of the $2016 \mathrm{NSCH}$, which is detailed in chapter four of this dissertation. Rationale for altering the methodology included a declining rate of public participation in phone interviews, decreased use of landlines, and increased costs associated with outreach to non-landline households (USCB et al., 2017). Methodological alterations to the data collection process for the $2016 \mathrm{NSCH}$ impact the 
comparability of the data, thereby limiting any ability to generate comparisons with previous versions of the NSCH (USCB et al., 2017).

The 2016 NSCH employed multiple methods to adjust for bias and secure a representative sample. The sampling procedure was well described; please refer to chapter four of this dissertation for further details. Oversampling was utilized to offset for bias related to age. Non-response bias was minimized by application of raking procedures to child race/ethnicity, sex, number of members living in the household, and household poverty ratio (USCB et al., 2017). Screener and detailed topical questionnaires for the 2016 NSCH were distributed and collected by both pencil and paper and web-based survey modalities. While oversampling was used to adjust for non-response bias, this cannot completely account for the difference between answers that could occur among caregivers who participated in the survey versus those who did not. Additionally, webbased technology assumes that families have access to the internet and may not address the differences in taking the survey via a smart phone, tablet, or home computer or in taking the survey via pencil and paper.

Questionnaires for the $2016 \mathrm{NSCH}$ utilized a wide variety of questions and response item types, however the data was often collected at nominal or ordinal levels of measurement. Capture of data at the categorical level places limitations upon the quality and granularity of the measure, however this is not an uncommon occurrence within large scale survey research (Polit \&Beck, 2017). The process of dealing with the missing data and imputed values into the public data files of the $2016 \mathrm{NSCH}$ are discussed in detail in chapter four of this dissertation. Hot deck imputation was applied to child demographic variables and regression imputation was applied to household size (3.67\%), poverty ratio 
(18.56\%), and Adult 1 education (3.04\%) (USCB et al. 2017). Langkamp, Lehman, and Lemeshow (2010) suggest that when more than $10 \%$ of cases are missing from within a large data set, imputation techniques are more appropriate than omitting cases with missing values.

While the 2016 NSCH clearly articulates the survey design, sampling procedure, and methods for data collection, there is minimal discussion involving the reliability and validity of the survey and the data it produces. This may be due to the recent release of the $2016 \mathrm{NCSH}$ data, and further investigation is needed pending the release of publications featuring use of this survey and the data it produced. This impacts the ability to interpret the results and/or conduct reliability and validity testing for any research that utilizes this dataset.

\section{Discussion of Results}

Survey data is based upon the perception of the individual responding to the survey. For the $2016 \mathrm{NSCH}$, the respondent is an adult caregiver with a child aged 0-5 years who lives in California. Respondents had to have an actual address or they were excluded from the survey. Self-report and non-response bias represent important consideration during the analysis and interpretation of results from survey generated data.

It is important to recognize that the results of this study are derived from unweighted data. The $2016 \mathrm{NSCH}$ does provide access to weighted data that provides a representative sample of children within the state of California, however this also would limit the capacity to apply predictive modeling to the data. While this does sacrifice generalizability of the results, using the unweighted data is appropriate as the specific aims of this research. 


\section{Sociodemographic characteristics}

Analysis of the sociodemographic and family culture characteristics reveal the study sample to be relatively homogenous. The cases within the unweighted sample of the California subset of the $2016 \mathrm{NSCH}(N=257)$ reflect that families predominantly featured married parents $(87.1 \%)$ with $3-4$ family members living at home; $89.5 \%$ of cases have at least one adult in the household who attended college $(89.5 \%)$ and $60 \%$ have no difficulty in meeting the basic needs for their families. This sample is skewed towards families that are doing well. Additionally, approximately 97\% of the families within the sample possessed health insurance. Private insurance was the most commonly reported insurance modality $(74.3 \%)$.

\section{Missing data: Emotional Support from place of worship}

One sociodemographic variable demonstrated a large percentage of missing data values. Descriptive analysis of families utilizing a place of worship or a religious leader for emotional support revealed a total of 65 missing data values ( $25 \%$ of the total sample) within this variable. With the missing data values excluded during calculation of the valid percentage value, an estimated $24.5 \%$ of the total population did seek emotional support from a religious source and $75.5 \%$ did not seek emotional support from a religious source. As missing values represent greater than $10 \%$ of the total for this variable, deleting the missing values and calculating a valid percentage increases the risk for bias (Langkamp et al., 2010). This variable would not have been an appropriate addition to include in a predictive model due to the large amount of missing values. 


\section{Family culture characteristics}

The majority of the cases within the sample reveal that the child was born in the United States $(96.1 \%)$ and $50 \%$ of households identify as third generation (both parents were born in the United States). English is the predominant language spoken at home within the sample. The child race/ethnicity variable demonstrated the greatest variance among the sociodemographic and culture characteristics within this study: $33.9 \%$ NonHispanic White, 28.4\% Hispanic, 21.4\% Asian, 13.6\% some other race and 2.7\% NonHispanic Black.

Data from the weighted version of the $2016 \mathrm{NSCH}$ is considered to be a representative sample of noninstitutionalized children in both the state and national levels (Child and Adolescent Health Measurement Initiative, 2018). Representativeness of the sociodemographic and family culture characteristics within the study sample was assessed by comparing various characteristics with the weighted data. Child and family culture characteristics from the weighted version of the California data for children aged 0 to 5 years from $2016 \mathrm{NSCH}$ demonstrate that English was the primary language spoken at home (74.6\%), the predominant parent marital status was married $(67.3 \%)$, the most educated adult in the household attended college or higher (53.5\%), and child race affiliation was mostly Hispanic (44\%) and White non-Hispanic (26.7\%). Families from the weighted California sample reported mostly second (39.5\%) and third generation $(45.5 \%)$ status.

Additionally, prevalence of race and Hispanic origin in California can also be compared to data from the United States Census Bureau (2018). The total population distribution of race/ethnicity in California in 2016 reflects $72.7 \%$ White alone, $38.9 \%$ 
Hispanic alone, 14.8\% Asian alone, and 6.5\% Black alone (United States Census Bureau, 2018). While the data from the United States Census Bureau is not specific to children, it does suggest similarity between the race/ethnicity of the pediatric population in California with the adult population at large in California. Comparison of the weighted and unweighted family culture characteristics reveal many similarities within the samples.

Despite efforts to statistically minimize bias (i.e .weighting the data), it remains salient to consider that the data from both the United States Census Bureau and the 2016 $\mathrm{NSCH}$ is only as representative as the individuals who chose to respond to the surveys. Ethnically diverse, immigrant, refugee, or other vulnerable populations may not be adequately represented by survey data that depends upon having a home address. While survey data may offer policymakers, clinicians, and advocates with cross-sectional slices of data regarding a specific population, these snapshots may fail to accurately capture the essence of the true population.

\section{Dependent and Independent Variables}

Questionnaire items within the 2016 NSCH survey were not initially created with the purpose of detailed measurement of pediatric preventative health care utilization nor family social capital. The investigator conducted extensive conceptual analysis and review of the literature to inform the variable selection for this research. A concept analysis was conducted and critical attributes of social capital were identified and appropriately matched to variables within the $2016 \mathrm{NSCH}$. The following sections discuss the results, reliability, and validity involving the dependent and independent variables for this study. 
Preventative Health Care Utilization. Measurement of the dependent variable of preventative health care utilization was determined and limited by the $2016 \mathrm{NSCH}$. The Bright Futures guidelines represent the gold standard for frequency of pediatric health maintenance visits in the United States (American Academy of Pediatrics, 2017a). Bright Futures recommends a higher frequency of pediatric health maintenance visits for younger children than older children, specifying seven health maintenance visits within the first year of life, three health maintenance visits within the first to second year of life, and two health maintenance visits within the second to third year of life.

The initial methodology for this research anticipated utilizing a dichotomous dependent variable to represent meeting or not meeting the Bright Futures recommendations for regularly scheduled child health maintenance visits. However, results from the descriptive analysis prompted reconsideration. While the distribution of ages of children in the sample was relatively normal, a wide variation existed between the conditions needed to meet the Bright Futures recommendations per age of the child. Despite the clearly delineated Bright Futures recommendations for the measurement of pediatric preventative care health visits, the $2016 \mathrm{NSCH}$ operationalized preventative health care utilization by assessing the frequency of visits to a physician or other appropriate health care provider over the past 12 months as a trichotomous variable, coded as $1=$ no visits, $2=1$ visit, and $3=2$ or more visits.

The Bright Futures Recommendations clearly highlight the gold standard for pediatric preventative health care utilization, however the 2016 NCSH did not measure the frequency of well-child visits per these established guidelines. As children at different ages have different recommendations for frequency of health maintenance visits, 
dichotomizing the dependent variable represents a risk of missing subtle nuances within age groups due to collapsing the data into a binary category. The data analysis plan was augmented from binary logistic regression to ordinal regression. Very little variation was noted within the dependent variable, which represents one of the most important limitations within this study.

Despite the seemingly skewed result of almost all of the children within the sample possessing health care insurance, it is important to consider that not all health insurance for children in the United States is created equally. Insurance plans under the ACA are required to cover preventative health care services for children, however, there is no standardized guideline that mandates which preventative services must be included within each different type of insurance plan. Variations among the services that are covered across Medicaid, private insurance plans, Tricare, or combined coverage plans can potentiate gaps in primary care services that impact the frequency of well-child visits, vaccination schedules, developmental screenings, dental assessments, and important child health education (Alpern et al., 2014; Halfon, 2016).

Age Distribution. The age distribution of the sample represents another important limitation to consider. Approximately $59.6 \%$ of the total sample needs one recorded preventative health care visit to meet recommendations, thereby skewing results to favor that the majority of the sample had met the criteria for recommended preventative health care utilization per age. There are significantly less children in the sample that necessitate more frequent health care utilization to meet recommendations; 22 of the children were less than 1 year old, 28 of the children were less than 2 years old, and 41 of the children were less than 3 years old. 
The only category of children that met $100 \%$ of the Bright Futures recommendations for preventative health care utilization was in the group of children aged 3-4 years. This is not surprising as the four-year old health maintenance visit is of special importance in the state of California. Passage of California Senate Bill 322 requires that children receive vaccinations prior to admittance in child care centers, day nursery schools, family day care homes, child development centers, and schools. As the four-year-old's visit is the last visit prior to the start of kindergarten, there may be a higher motivation element to attend the visit due to the statewide requirement for vaccinations prior to initiating school.

An interesting finding within the health care utilization pattern of children aged 35 years old is that there was unexpected reporting of greater than one health maintenance visit per year. This study did not differentiate among healthy children, children with chronic health conditions, or children with special health care needs. As children with chronic health conditions or special health care needs may require a greater incidence of health maintenance visits (such as asthma re-check visits or maintenance visits with specialty clinics), this may explain why the results for some of the children demonstrated a greater frequency of visits than what would be expected. While some healthy adolescents do attend separate health maintenance visits for well-child checks and sports physicals, there is no way to differentiate this for this age group (0-5 years) within this dataset. It is also possible the adult caregiver respondents may have misunderstood the nature of the question, representing a threat to the validity of the survey question.

Social Capital. The concept of social capital refers to the resources obtained via membership and interaction within social networks including both structural and 
functional aspects (Bourdieu, 1986; Coleman, 1990; Putnam, 2000). The structural aspects of social capital include networks and bonds, with networks defined within a socioecological context encompassing individual, family, community, and governmental tiers. Family social capital refers specifically to those resources that result from membership and interaction within a family network. The functional aspects of social capital are divided into cognitive (what families perceive) and behavioral (what families do) domains. A concept analysis exploring social capital and nursing defined the critical attributes used to operationalize family social capital for this research. These include trust, reciprocity, shared values, solidarity, social norms, safety, participation, communication, and frequency of social interaction.

Social Capital and nursing. Analysis of the literature involving social capital and nursing revealed multiple trends. The concept of social capital in the nursing literature over the past 20 years is solidly supported by the theoretical underpinnings of seminal social capital scholars Putnam, Coleman, and Bourdieu. However, social capital continues to endure critique due to its association with subjective data, conceptual confusion, variation in measurement modalities, and poor reporting of psychometric properties.

\section{Subjective nature of social capital}

The subjective nature of social capital contributes to the criticism of the concept. While the successful application of numerical scaling techniques to subjective measures and the growing field of psychometrics has increased acceptance of subjective data, subjective measures still receive critique for being "softer" than their objective 
counterparts (Waltz et al., 2017; McDowell, 2006). This likely exists as a reflection of the preference for empirical data within the scientific community.

\section{Multiple definitions of social capital}

As social capital can be measured across a socioecological spectrum that extends across individual, family, school, community, and government levels, additional work is needed to explore social capital within the context of the specified socioecological level as well as from cultural and multilevel approaches. Further conceptual clarity could be achieved by conducting multidisciplinary concept analyses, systematically reviewing the results, constructing a concise multidisciplinary operational definition, and supplementing the validity of the definition and attributes via population specific qualitative interviews.

Notably, there are almost as many conceptual/theoretical papers as empirical quantitative studies. While the copious theoretical call to action papers are inspirational and informative, they may lack the rigor and/or data to justify their recommendations. Only seven of the 78 articles included in this analysis represented qualitative research, which demonstrates an interesting mismatch between the published conceptual papers and the availability of qualitative data. This gap supports a clear need for further conceptual clarity regarding the concept of social capital.

\section{Controversy in measuring social capital}

The psychometric community remains divided among the utility of measuring health from a health index perspective or from a health profile perspective. The health index perspective refers to when scores from different instruments are combined into one overall score (McDowell, 2006). Used commonly within the context of economic 
analysis and policy decision making, the health index perspective involves data that is collected by generic instruments and then collapsed into a single score (McDowell, 2006). Rather than collapsing the data into a single score, the profile perspective includes each score as a separate unit within the analysis. Critics of health index measurement approach question the veracity of combining the scores of different instruments whereas critics of health profile measurement approach question the generalizability of findings. (McDowell, 2006). The majority of social capital instruments measure social capital within a health index format rather than a health profile format. The concept of social capital may be richened through idiographic exploration as individual experiences and complexity may provide a fuller understanding of the concept. Regardless of profile or index measurement types, most of the instruments used to measure social capital within this analysis offered poor reporting of psychometric properties.

Measurement of social capital remains reliant upon aggregating individual responses to represent an overall collective measure within the specified socioecological level (Harpham et al., 2002; Kawachi et al., 2010). Community social capital is often measured as dichotomous or ordinal with high or low levels (Harpham et al., 2002). Variance in levels of social capital between communities can be confounded by the characteristics of the individuals within the community, therefore representing an important limitation when considering comparability (Kawachi et al., 2010).

As there is no consensus for one solitary definition nor measurement of social capital, examination of reliability and validity remains an iterative process. A systematic review of measurement methodology involving social capital and mental health conducted by DeSilva (2006) revealed only 4 out of 28 social capital studies included 
validity testing. Further review of the literature confirms that few studies include validation of social capital instruments or analysis of psychometric properties. Some researchers such as Van Deth (2003) strongly suggest that all components within social capital undergo multiple item analysis, rigorous data reduction techniques, and psychometric analysis. Others suggest that omitting respondent perspectives within psychometric analysis represents a vital flaw in truly understanding the meaning of the data. (Kawachi et al., 2010; Waltz et al., 2017). As there is currently no gold standard of measurement for social capital, it is currently not possible to assess for concurrent validity (DeSilva, Harpham,Tuan, Bartolini, Penny, \& Huttly, 2006).

Social capital in the nursing workforce. A final trend was associated with the most common theme identified among quantitative articles that involved social capital and nursing. Quantitative discourse involving nursing and social capital over the past 20 years is overwhelmingly skewed towards studying nurses and the nursing workforce. Social capital gained attention in nursing research due to its applications toward health promotion and community wellness, however results of this analysis reveal that social capital research in nursing is less about patients and more about nurses and the nursing work environment.

Family Social Capital. The 2016 NSCH was not specifically designed to measure family social capital. However, using secondary survey data to explore social capital is a common practice in the world of social capital research. Social capital is often measured via indicators from larger surveys that explore perceptions, behaviors, and health outcomes (Harpham in Kawachi et al., 2010). This is largely due to lack of a reliable standardized instrument that produces valid data. The critical attributes of social 
capital were embedded within the study via a process of matching the attributes with the most appropriate available variable within the $2016 \mathrm{NSCH}$.

Correlations. As the 2016 NSCH contains multi-item reflective scales, the family social variables are expected to demonstrate inter-correlation due to a shared overlying concept (Polit \& Beck, 2017). This may explain the incidence of small positive correlations among the family social capital variables. One large positive correlation existed between the days per week reading to child and days per week telling stories or singing to the child. (rho $0.585, \mathrm{n}=215, \mathrm{p}<0.001$ ). Days per week spent reading with the child and days per week telling stories or signing songs with the child are conceptually and behaviorally similar. However, an interesting distinction between these variables is that one of them requires that the caregiver is able to read while the other does not. Had a predictive model been generated, either days per week spent reading to the child or days per week telling stories or singing songs with the child would have been excluded due to the large positive correlation between them. Directionality nor causal inference can be ascertained from these associations.

Defining and measuring social capital represent challenges due to its complexity and abstraction. While this research is informed by a strong conceptual framework and a concept analysis on social capital in nursing, results cannot be generalized across all research that involves social capital and health. Despite the challenges of defining and measuring social capital, this does not negate its potentially important role in health and offers opportunity for further investigation. 


\section{Implications for Health Policy}

\section{Demographic trends involving children and families in the United States.}

The fairly homogenous sample of cases from California subset of the 2016 NSCH is not generalizable, nor able to account for the changing demographic trends involving children and families across the United States. Marriage rates are declining, divorce rates are climbing, and approximately forty $\%$ of children born in the United States are born to unwed parents (Centers for Disease Control and Prevention, 2016; McLanahan, Haskins, Garfinkel, Mincy, \& Donahue, 2010 Forum on Child and Family Statistics, 2016).

Disproportionate disparities and inequities exist for families with children of non-marital birth versus their married counterparts (McLanahan et al., 2010; Kalil \& Ryan, 2010; Hummer \& Hamilton, 2010; Waldfogel, Cragigie, \& Brooks-Gunn, 2010). By 2044, the United States Census Bureau (2015) predicts that the population will increase to 400 million people. More than half of all Americans in 2044 are projected to belong to racial or ethnic minority groups. Data supports that single parents and racial or ethnic minority groups do not share the same health outcomes than their married white counterparts.

The economic impact of disadvantaged environments. Of the 46.7 million Americans living in poverty, children represent approximately $21 \%$ of the total population (The United States Census Bureau, 2015). Evidence supports that exposures to stressors early in life are linked to alterations in brain development, poor health outcomes, decreased academic achievement, and lifelong adversity (Shonkoff, Garner, The Committee on psychosocial aspects of child and family health, \& The Committee on early childhood, adoption, \& dependent care, 2012; Halfon, Wise, \& Forrest, 2014). Children living in poverty are exposed to a host of stressors including suboptimal 
nutrition, unstable family structure, unreliable living conditions, environmental hazards, and poor access to health care (Levey \& Sidel, 2013; Shonkoff et al., 2012; IOM, 2013).

Holzer, Schanzenbach, Duncan, \& Judwig (2008) estimate the cost of childhood poverty by comparing future increased social expenditure and lost productivity. Using this formula, Holzer et al (2008) postulate that the annual economic burden of childhood poverty in the United States is approximately $\$ 500$ billion. Most economists classify health care expenditures as consumption. However, a life course health development perspective challenges this notion by viewing health care expenditures as investments in health capital that lead to long term health reserves (Holzer at al., 2008). Expenditures towards positive momentum in early developmental health may result in decreased midlife health care costs, economic growth, improved employment productivity, and generational health and wellness (Halfon, 2016; Heckman, 2013). Many of the symptoms of early childhood adversity may not show up until years or decades post initial exposure (Halfon et al., 2014). As an economy grows and competes, it is essential for $60 \%$ of workers to be well educated and skilled. The United States will lose approximately $30 \%$ of potential productivity as children burdened with health problems age and attempt to enter the work force (Holzer et al., 2008.).

Childhood represents one of the most critical time periods in human health development. Efforts to improve American health and wellness across the life course may be optimized when focused on critical sensitive time periods of health development. While the concept of social capital represents a type of social scaffolding with the potential to mitigate the effects of negative life exposures across the life course, additional evidence is needed to support this hypothesis. 


\section{Implications for future research}

This is the first study that investigates the relationship between pediatric preventative health care utilization and family social capital. Additionally, this is the first study that explores family social capital and utilization of preventative health care services with data from the $2016 \mathrm{NSCH}$. The conceptual framework for this study is strong and selection of variables was critically informed by the integration of theory, a comprehensive review of the literature, and an evolutionary concept analysis. While the results of this dissertation did not demonstrate a statistically significant association between family social capital and utilization of pediatric preventative health care services, evidence presented in this section supports that characteristics of the 2016 $\mathrm{NSCH}$ as well as the data from the survey, represent that most potent limitation of this study. Lack of variability within the dependent variable, use of categorical data, and homogeneity of the sample contribute to the non-significant results of this research.

Accessibility and utilization of health care services represent important aspects that influence child health. Descriptive analysis of the cases within this study demonstrated that $97 \%$ of the families had health insurance and private insurance at $74 \%$ represented the most common type of health insurance. It is not unexpected the sample reflects that the majority of the children within the sample have access to the health care delivery system via possession of health insurance and that they are attending preventative health care visits. This is consistent with national patterns of pediatric insurance status and health care utilization across the United States. Due to the nominal 
and categorical nature of the data collected by the $2016 \mathrm{NSCH}$, it is not possible to ascertain the true frequency of preventative health care visits in children aged 0 to less than 2 years. The measurement of the dependent variable of frequency of visits to health care provider over the previous 12 months was not the best way to measure pediatric preventative health care utilization.

Future studies involving pediatric health care utilization may benefit from using more comprehensive measures for health care utilization including continuous measurement of frequency of visits, use of both caregiver subjective survey report and objective documentation from an electronic health record, incorporating data involving child vaccination status and completion, and considering differences in preventative health care utilization for children with chronic health conditions and/or children with special health care needs. Additionally, maximizing the variability within the variables will improve statistical conclusion validity. Schlmoer and Copp (2014) recommend strategies to enhance the validity of data from large datasets by either replicating the study with actual patients, addressing the same research question with a different large data set, and comparing the results with the initial research study. Replicating the study with a larger sample size and better measures may influence the effect size and statistical conclusion validity of the research. Additionally, $2016 \mathrm{NSCH}$ does not report reliability or validity. The weaknesses and limitations of this research continue to justify further research.

The concept of social capital will benefit from further investigation in conceptual clarity, multidisciplinary commonalities, consistency in measurement, and better incorporation of diverse populations. More qualitative and quantitative research is needed 
in order to understand the utility of social capital as a framework for nursing and public health, however the concept offers an opportunity to enhance the discourse surrounding life course health trajectories that emphasize health development, health capacity, and health investment.

\section{Implications for nursing}

Health care policy trends such as population health and patient engagement emphasize the impact of social influences upon health (SIH). Conceptualizing health as a social phenomenon offers a lens to guide innovative research for the purpose of gleaning a better understanding of the SIHs. Defining and measuring concepts that involve SIHs represent challenges due to their complexity, abstraction, and the wide variation across the human experience (McDowell, 2006). Populations do not comprise disconnected individuals that do not interact, mediate, or moderate. Complex yet subtle social influences such as social capital may hold the key towards a deeper understanding of population health (Muntaner, Lynch, \& Smith, 2000).

The challenges for future nurse leaders involve remaining anchored to the roots of the profession, navigating the weeds, and continuing to foster further growth. Ultimately, nursing and the concept of social capital share a commonality as both serve as cohesive forces that connect complex systems. The majority of social capital in the nursing literature currently exists within the context of the nursing workforce, however nursing research and practice have more to contribute to public health than what exists within the confines of hospitals.

The discipline of nursing occupies a unique space within health care to influence social determinants of health. As trusted caregivers and health care providers, nurses 
operate on the front lines of health care and regularly foster relationships and navigate connections among patients, families, the health care system, and other intersecting environments. Social capital has appeared in multidisciplinary literature as a social determinant of health as well as a potential social scaffolding to mitigate the effect of negative socioecological life exposures. A better understanding of the power within these social connections may hold the capacity to influence health outcomes. Nursing pioneer Lilian Wald's vision of unification, interaction, and connection, as is the concept of social capital, remain salient for both the future of child health and the future of nursing. 


\section{References}

Ahern, M. M., \& Hendryx, M. S. (2003). Social capital and trust in providers. Social Science and Medicine, 57(7), 1195-1203.

Alpern, E. R., Clark, A. E., Alessandrini, E. A., Gorelick, M. H., Kittick, M., Stanley, R. M., . . Chamberlain, J. M. (2014). Recurrent and high-frequency use of the emergency department by pediatric patients. Academic Emergency Medicine. 21, 365-373.

Alvarez, E. C. \& Romani, J. R. (2017). Measuring social capital: Further insights. Gac Sanit, 31(1), 57-61.

Alvarez, E. C., Kawachi, I., \& Romani, J. R. (2017). Family social capital and health: A systematic review and redirection. Sociology of Health and Illness, 39(1), 5-29.

American Academy of Pediatrics. (2017a). Bright Futures/American Academy of Pediatrics: Recommendations for preventative pediatric health care. Accessed on April 3, 2018 at https://www.aap.org/en-us/documents/periodicity_schedule.pdf. American Academy of Pediatrics. (2017b). Bright futures: Prevention and health promotion for infants, children, adolescents, and their families. Accessed on July 16, 2017 at https://brightfutures.aap.org/about/Pages/About.aspx.

Anda, R. F., Felitti, V. J., Bremner, J. D., Walker, J. D., Whitfield, C., Perry, B. D., .. . Giles, W. H. (2006). The enduring effects of abuse and related adverse experiences in childhood: A convergence of evidence from neurobiology and epidemiology. European Archives of Psychiatry and Clinical Neuroscience, 256(3), 174-186. 
Avant and Walker. (2011). Strategies for theory construction in nursing. ( $\left.5^{\text {th }} \mathrm{ed}\right)$. Upper Saddle River, NJ: Pearson Education Inc.

Barker, D. J. P. (1998). Mothers, babies and health in later life. Edinburgh: Churchill Livingstone.

Barrett \& Turner (2005). Family structure and mental health: The mediating effects of socioeconomic status, family process, and social stress. Journal of Health and Social Behavior, 2(46), 156-169.

Blanchard, L. T., Gurka, M. J., \& Blackman, J. A. (2006). Emotional, developmental, and behavioral health of American children and their families: A report from the 2003 National Survey of Children's Health. Pediatrics, 117(6), 1202-1212.

Blumenshine, P., Egerter, S., Barclay, C. J., Cubbin, C., \& Braveman, P. A. (2010).

Socioeconomic disparities in adverse birth outcomes: A systematic review. American Journal of Preventive Medicine, 39(3), 263-272. doi:

10.1016/j.amepre.2010.05.012.

Bourdieu, P. (1986). The forms of capital. In: J. Richardson (Ed.), Handbook of Theory and Research for the sociology of education. New York, NY: Macmillian New York.

Bronfenbrenner, U. (1979). The ecology of human development: Experiments by nature and design. Cambridge, MA: Harvard University Press.

Burns, C. E., Dunn, A. M., Brady, M. A., Starr, N. B., Blosser, C. G., \& Garzon, D.L. (2017). Pediatric Primary Care. (6 $6^{\text {th }}$ ed.). St. Louis, MO: Elsevier.

Carlson, E. D. \& Chamberlain, R. M. (2003). Social capital, health, and health disparities. Journal of Nursing Scholarship, 35(4), 325-331. 
Carter, B. (2014). Child poverty: Limiting children's life chances. Journal of Child Health Care, 18(1), 3-5. DOI:10.1177/1367493514522726

Centers for Disease Control and Prevention. (2013). 2011-2012 National Survey of Children's Health Frequently Asked Questions. Available from URL: http://www.cdc.gov/nchs/slaits/nsch.htm

Centers of Disease Control and Prevention. (2016) Unmarried childbearing. Retrieved on 3/13/2016 from: http://www.cdc.gov/nchs/fastats/unmarried-childbearing.htm.

Centers for Disease Control and Prevention (2017). National Center for Health Statistics. Leading Causes of Death, Children 1-4, 5-14. Retrieved on July 16, 2017 from https://www.cdc.gov/nchs/fastats/child-health.htm

Cheng, T. L., Emmanual, M. A., Levy, D. J., \& Jenkins, R. R. (2015). Child health disparities: What can clinicians do? Pediatrics, 136(5), 961-968. DOI: 10.1542/peds.2014-4126.

Child and Adolescent Health Measurement Initiative, Data Resource Center. (2018) Data snapshots: California. Retrieved on March 25, 2018 from http://childhealthdata.org/browse/data-snapshots/state-snapshot?geo=6

Cohen, J. W. (1988). Statistical power analysis for behavioral sciences $\left(2^{\text {nd }}\right.$ ed). Hillsdale, NJ: Lawrence Erlbaum Associates.

Coleman, J. S. \& Hoffer, T. (1987). Public and private schools: The impact of communities. New York, NY: Basic Books.

Coleman, J. S. (1990). Foundations of social theory. Cambidge, MA: First Harvard University Press. 
Conger, R. D., Conger, K. J., Elder, G. H., Lorenz, R. O., Simons, R. I., \& Whitbeck, L. B. (1992). A family process model of economic hardship and adjustment of early adolescent boys. Child Development, 63, 526-541.

Derose, K. P. \& Varda, D. M. (2009). Social capital and health care access: A systematic review. Medical Care Research and Review, 66(3), 272-306.

Duke, N. N., Skay, C. L., Pettingell, S. L., \& Borowsky, I. W. (2009). From adolescent connections to social capital: Predictors of civic engagement in young adulthood. Journal Adolescent Health, 44, 161-168.

Elder, G. H., Nguyen, T. V., \& Caspi, A. (1985). Linking family hardship to children's lives. Child Development, 56, 361-375.

Felitti, V. J., Anda, R. F., Nordenberg, D., Williamson, D. F., Sapitz, A. M., Edwards, V., ... Marks, J. S. (1998). Relationship of childhood abuse and household dysfunction to many of the leading causes of death in adults: The Adverse Childhood Experiences (ACE) study. American Journal of Preventive Medicine, 14(4), 245-258

Field, J. (2017). Social Capital. ( $3^{\text {rd }}$ ed.). New York, NY: Routledge.

Forum on Child and Family Statistics. (2016). Births to unmarried women. Retrieved on 2/29/16 from: http://www.childstats.gov/americaschildren/family2.asp.

Forsdahl, A. (1977). Are poor living conditions in childhood and adolescence an important risk factor for arteriosclerotic heart disease? British Journal of Preventive \& Social Medicine, 31(2), 91-95.

Fukuyama, F. (2001). Social capital, civil society, and development. Third World Quarterly, 22(1), 7-20. 
Gootaert, C., \& Van Bastelaer, T. (2002). Understanding and measuring social capital. Washington DC: The World Bank.

Granovetter. M. S. (1973). The strength of weak ties. American Journal of Sociology, 78(6), 1360-1380.

Halfon, N. (2016). Socioeconomic influences on child health: Building new ladders of opportunity. JAMA-The Journal of the American Medical Association, 311(4), 929-936. doi: 10.001/jama.2014.607.

Halfon, N., Larson, K., Lu, M., Tullis, E., \& Russ, S. (2014). Lifecourse health development: Past, present, and future. The Journal of Maternal and Child Health, 18, 344-365. doi 0.1007/s10995-013-1346-2.

Halfon, N., Wise, P. H., \& Forrest, C. B. (2014). The changing nature of children's health development: New challenges require major policy solutions. Health Affairs, 33(12), 2116-2124.

Harpham, T., De Silva, M.J., \& Tuan, T. (2006). Maternal social capital and child health in Vietnam. Journal of Epidemiology and Community Health, 60, 865-871. doi:10.1136/jech2005.044883.

Harpham, T., Grant, E., \& Rodriguez, C. (2004). Mental health and social capital in Cali, Colombia. Social Science and Medicine, 58, 2267-2277.

Heckman, J. (2013). Giving kids a fair chance. Boston, MA:Massachusetts Institute of Technology.

Holtgrave, D. R., \& Crosby, R. (2006). Is social capital a protective factor against obesity and diabetes? Findings from an exploratory study. Annals of Epidemiology, 16(5), 406-408. 
Holzer, H. J., Schanzenbach, D. W., Duncan, G. J., \& Judwig, J. (2008). The economic costs of poverty in the United States: Subsequent effects of children growing up poor. Available from: https://eric.ed.gov/?id=ED509921

Hsieh, C. (2008). A concept analysis of social capital within a health context. Nursing Forum, 43(3), 151-159.

Hummer, R. A. \& Hamilton, E. R. (2010). Race and ethnicity in fragile families. The Future of Children, 20(2), 113-131.

Institute of Medicine and National Research Council. (2013). U.S. Health in International Perspective: Shorter Lives, Poorer Health. Washington, DC: The National Academies Press. https://doi.org/10.17226/13497

Isaacs, J. B. (2012). Starting school at a disadvantage: The school readiness of poor children. Center on Children and Families at Brookings accessed on 4/3/18 via https://www.brookings.edu/wpcontent/uploads/2016/06/0319_school_disadvantage_isaacs.pdf

Kalil, A. \& Ryan, R. M. (2010). Mothers' economic conditions and sources of support in fragile families. The Future of Children, 2(2), 39-61.

Kawachi, I., Subramanian S. V., \& Kim, D. (2010). Social capital and health. New York, NY: Springer.

Kawachi, I, \& Berkman, L. (2010). Social cohesion, social capital, and health. Social Epidemiology, 174-190. Available at https://www.researchgate.net/publication/303125151_Social_cohesion_social_cap ital_and_health 
Kawachi, I., Kennedy, B., \& Glass, R. (1999). Social capital and self-rated health: A contextual analysis. American Journal of Public Health, 89, 1187-1193.

Kawachi, I., Kennedy, B., Lochner, K., \& Prothrow-Stith, D. (1997). Social capital, income equality, and mortality. American Journal of Public Health, 87, 14911498.

Kirby, J. B. \& Kaneda, T. (2005). Neighborhood socioeconomic disadvantage and access to health care. Journal of Health and Social Behavior, 46(1), 15-31.

Kominski, G. F. (2014). Changing the U.S. Health Care System (4 ${ }^{\text {th }}$ ed.). San Fransisco, CA: Wiley and Sons.

Koutra, K., Orfanos, P., Roumeliotaki, T., Kritsotakis, G., Kokkevi, A., \& Philalithis, A. (2012). Psychometric validation of the youth social capital scale in Greece. Research in Social Work Practice, 22(3), 333-343.

Kritsotakis, G. \& Gamarnikow, E. (2004). What is social capital and how does it relate to health? International Journal of Nursing Studies, 41, 43-50. doi:10.1016/S00207489(03)000097-X.

Langkamp, D.L., Lehman, A., \& Lemeshow, S. (2010). Techniques for Handling Missing Data in Secondary Analyses of Large Surveys. Academic Pediatrics.10(3): 205210. doi:10.1016/j.acap.2010.01.005. Retrieved on 3/17/2018 via https://www.ncbi.nlm.nih.gov/pmc/articles/PMC2866831/pdf/nihms174582.pdf

Law, M., Wilson, K., Eyles, J., Elliot, S., Jerret, M., Moffat, T., \& Luginaah, I. (2005). Meeting health need, accessing health care: The role of the neighborhood. Health and Place, 11(4), 367-377. 
Lempers, J. D., Clark-Lempers, D., \& Simons, R. L. (1989). Economic hardship, parenting, and distress in adolescence. Child Development, 60, 25-39.

Levy, B. S. \& Sidel, V. W. (2013). Social Injustice and Public Health. New York, NY: Oxford University Press.

Lin, N. (1999). Building a network theory of social capital. Connections, 22(1), 28-51.

Lin, N. (2001). Social capital. Theory and research. New York, NY: Aldine De Gruyter.

Lochner, K. A., Kawachi, I, Brennan, R. T., \& Buka, S. L. (2003). Social capital and neighborhood mortality rates in Chicago. Social Science and Medicine, 56(8), 1797-1805.

Looman, W. S. (2006). Development and testing of the social capital scale for families of children with special health care needs. Research in Nursing and Health, 29(4), $325-336$.

Looman, W. \& Farrag, S. (2009). Psychometric properties and cross-cultural equivalence of the Arabic Social Capital Scale: Instrument development study. International Journal of Nursing Studies, 46(1), 44-53.

Looman, W. S. \& Lindecke, L. L. (2004). Health and social context: Social capital's utility as a construct for nursing and health promotion. Journal of Pediatric Health Care, 19(2), 90-94.

Loury, G. C. (1977). A dynamic theory of racial income differences. In: P. A. Wallace \& A. L. Mund (Eds.) Pp. 153-186, Women, minorities, and employment discrimination. Lexington, MA: Lexington Books.

Luby, J., Belden, A., Botteron, K., Marrus, N., Harms, M. P., Babb, C., . . Barch, D. (2013). The effects of poverty on childhood brain development: The mediating 
effect of caregiving and stressful life events. JAMA Pediatrics, 167(12), 11351142.

Lynch, J. W., Davey Smith, G., Harper, S., Hillemeier, M. M., Ross, N., Kaplan, G. A., \& Wolfson, M. (2004). Is income inequality a determinant of population health? Part 1: A systematic review. The Milbank Quarterly, 82(1), 5-99.

Lynch, J. W., Davey Smith, G., Hillemeier, M. M., Shwa,M., Raghunathan,T., \& Kaplan, G. A. (2001). Income inequality, the psychosocial environment and health: Comparisons of wealthy nations. Lancet, 358, 194-200.

Macinko \& Starfield (2001). The utility of social capital in research on health determinants. The Milbank Quarterly, 79(3), 387- 427.

Marmot, M. (2005). Social determinants of health inequalities. The Lancet, 365(9464), 1099-1104.

Marmot, M., Shipley, M. J., Brunner, E., \& Hemingway, H. (2001). Relative contribution of early life and adult socioeconomic factors to adult morbidity in the Whitehall II Study. Journal of Epidemiololgy and Community Health, 55(5), 301-307.

McDowell, I. 2006. Measuring Health: A guide to rating scales and questionnaires. ( $3^{\text {rd }}$ ed). New York, New York: Oxford University Press.

McLanahan, S., Haskins, R., Garfinkel, E., Mincy, R. B., \& Donahue, E. (2010). Introducing the issue. The Future of Children, 20(2). Retrieved on 2/18/2016 from:

http://www.princeton.edu/futureofchildren/publications/journals/article/index.xml ?journalid $=73 \&$ articleid $=528 \&$ sectionid $=3635 \&$ submit . 
Meaney, M. J. (2001). Maternal care, gene expression, and the transmission of individual differences in stress reactivity across generations. Annual Review of Neuroscience, 24, 1161-1192.

Meaney, M. J. (2010). Epigenetics and the biological definition of gene $\times$ environment interactions. Child Development, 81(1), 41-79.

Morrow, V. (2004). Children's "social capital": Implications for health and well-being. Health Education, 104(4), 211-225.

Muntaner, C., Lynch, J., \& Smith, G. D. (2000). Social capital and the third way in public health. Critical Public Health, 10(2), 213-237.

National Survey of Children's Health (2013). 2011-2012 NSCH: Child Health Indicator and Subgroups SPSS Codebook, Version 1.0. Available at http://childhealthdata.org/learn/NSCH/resources/codebooks

Neves, B. B. (2013). Social capital and internet use: The irrelevant, the bad, and the good. Sociology Compass, 7(8), 599-611.

Organization for Economic Co-operation and Development (OECD). (2001). The wellbeing of nations: The role of human and social capital. Available at http://www.oecd.org/site/worldforum/33703702.pdf

Pallant, J. (2016). SPSS survival manual: A step by step guide to data analysis using IBM SPSS. (6 ${ }^{\text {th }}$ ed.). New York, NY: McGraw-Hill.

Pascoe, J. M., Specht, S., McNicholas, C., Kasten, E., Spears, W., \& Looman, W. (2013). Correlates of mothers' perception of their communities' social capital: A community-based study. Journal of Maternal and Child Health. 17,1382-1390. 
Polit, D. F. \& Beck, C. T. (2017). Nursing research: Generating and assessing evidence for nursing practice. (10 ${ }^{\text {th }}$ ed.). China: Wolters Kluwer.

Porta, M. (2014) Porta's Dictionary of Epidemiology. (6 ${ }^{\text {th }}$ ed.). New York: NY: Oxford University Press.

Portes, A. (1998). Social capital: Its origins and applications in modern sociology. Annual Review of Sociology, 24, 1-24.

Putnam, R. (2000). Bowling Alone. The collapse and revival of American community. New York, NY: Simon and Schuster.

Read, E. A. (2013). Workplace social capital in nursing: An evolutionary concept analysis. Journal of Advanced Nursing, 70(5), 997-1007. doi: 10.1111/jan.12251

Rosenbaum, S. \& Blum, R. (2015). How healthy are our children? The Future of Children, 25(1), 11-34. Available at https://futureofchildren.princeton.edu/sites/futureofchildren/files/media/policies_t o_promote_child_health_25_full_journal.pdf

Rudestam, K. E. \& Newton, R. R. (2015). Surviving your dissertation: A comprehensive guide to content and process. $\left(4^{\text {th }} \mathrm{ed}.\right)$. Thousand Oaks, CA: Sage.

Schlmoer, B. J. \& Copp, H. L. (2014). Secondary data analysis of large data sets in urology: Successes and errors to avoid. The Journal of Urology, 191, 587-596.

Schultz, T. W. (1961). Investment in Human Capital. American Economic Review, 51, 117.

Sheingold, B. H., \& Sheingold,S. H. (2013). Using a social capital framework to enhance measurement of the nursing work environment. Journal of Nursing Management, 12(5), 790-801. 
Shonkoff, J. P., Garner, A. S., \& The Committee on Psychosocial Aspects of Child and Family Health; Committee on Early Childhood, Adoption, and Dependent Care; Section on Developmental and Behavioral Pediatrics. (2012). The lifelong effects of early childhood adversity and toxic stress. Pediatrics, 21, 2011-2663. Accessed on March 12, 2016 athttp://pediatrics.aappublications.org/content/early/2011/12/21/peds.2011$\underline{2663.18}$

Social Capital. (n.d.) In Oxford's online dictionary. Retrieved on June 16, 2017 from https://en.oxforddictionaries.com/definition/social_capital

Social Capital. (n.d.) In The Free Dictionary.com. Retrieved on May 10, 2018 from https://www.thefreedictionary.com/social+capital

Spence Lachinger, H.K., Read, E., Wilk, P., \& Finegan, J. (2014). The influence of nursing unit empowerment and social capital on unit effectiveness and nurse perceptions of patient care quality. Journal of Nursing Administration, 44(6), 347352. doi: 10.1097/NNA.0000000000000080.

Stone, W. (2001). Measuring social capital: Towards a theoretically informed measurement framework for researching social capital in family and community life. (Research Paper No. 24). Melbourne, Australia: Australian Institute of Family Studies.

Story, W. (2014). Social capital and the utilization of maternal and child health services in India: A multilevel analysis. Health and Place, 28,73- 84.

Stromgren, M., Eriksson, A., David Bergman, D, \& Dellve, L., (2016). Social capital among healthcare professionals: A prospective study of its importance for job 
satisfaction, work engagement and engagement in clinical improvements.

International Journal of Nursing Studies, 53, 116-25. doi:

10.1016/j.ijnurstu.2015.07.012

Sundquist, J., Johansson, S. E., Yang, M., \& Sundquist, K. (2006). Low linking social capital as a predictor of coronary heart disease in Sweden: A cohort study of 2.8 million people. Social Science and Medicine, 62(4), 954-963.

Szreter, S., \& Woolcock, M. (2004). Health by association? Social capital, social theory and the political economy of public health. International Journal of Epidemiology, 33, 331-339.

Taylor, P., Funk, C., \& Clark, A. (2007). Generation gap in values, behaviors: As marriage and parenthood drift apart, public is concerned about social impact. Washington, DC: Pew Research Center. Retrieved on 3/5/2016 from: http://www.pewsocialtrends.org/2007/07/01/as-marriage-and-parenthood-driftapart-public-is-concerned-about-social-impact/.

Thompson, E., Hanson, T. L., \& McLanahan, S. S. (1994). Family structure and child well-being: Economic resources vs. parental behaviors. Social Forces, 1, 221-242.

United States Census Bureau. (2015). Projections of the size and composition of the US Population: 2014- 2060. Retrieved on March 5, 2016 from: http://www.census.gov/newsroom/press-releases/2015/cb15-tps16.html . United States Census Bureau. (2018). Quick Facts: California. Retrieved from https://www.census.gov/quickfacts/CA on March 25, 2018. 
United States Census Bureau, Associate Director of Demographic Programs, National Survey of Children's Health. (2017). 2016 National Survey of Children's Health Frequently Asked Questions. September 2017. Available from: https://www.census.gov/content/dam/Census/programs-surveys/nsch/techdocumentation/methodology/NSCH\%202016\%20FAQs.pdf

Uphoff, E. P., Pickett, K. E., Cabieses, B., Small, N., \& Writght, J. (2013). A systematic review of the relationships between social capital and socioeconomic inequalities in health: A contribution to understanding the psychosocial pathway of health inequalities. International Journal for Equity in Health, 12(54),1-2. Available at http://www.equityhealthj.com/content/12/1/54

Wadsworth, M. E. J. (1987). Follow-up of the first national birth cohort: Findings from the Medical Research Council National Survey of Health and Development. Paediatric and Perinatal Epidemiology, 1(1), 95-117.

Waldfogel, J., Cragigie, T. A., \& Brooks-Gunn, J. (2010). Fragile families and child well being. The Future of Children, 20(2), 87-112.

http://www.futureofchildren.org/futureofchildren/publications/journals/article/index.xml? journalid=73\&articleid $=532$.

Waltz, C.F., Strickland, O.L., and Lenz, E.R. (2017). Measurement in Nursing and Health Research. 5th Edition. New York: Springer Publishing Company.

Wang, H., Northridge, M. E., Kunzel, C., Zhang, Q., Kum, S. S., Gilbert, J. L., . . . Metcalf, S. S. (2016). Modeling social capital as dynamic networks to provide access to oral healthcare. Department of Health and Human Services. Retrieved on $10 / 10 / 16$ from the pub med database 
https://www.ncbi.nlm.nih.gov/pmc/articles/PMC5031478/.

Wen, M. (2008). Family structure and children's health and behavior. Journal of Family Issues, 29(11), 1492-1519. doi:10.1177/0192513X08320188.

Widmer, E. D., Kempf-Constantin, N., Robert-Tissot, C., Lanzi, F., \& Carminati, G. G. (2008). How central and connected am I in my family? Family-based social capital of individuals with intellectual disability. Research in Developmental Disabilities, 29(2), 176-187.

Wilkinson, R. G. (1996). Unhealthy societies: The afflictions of inequality. New York, NY: Routledge.

Wisk, L. E. \& Witt, W. P. (2012). Predictors of delayed or forgone needed health care for families with children. Pediatrics, 130(6), 1027-1037.

Woolcock, M. (1998). Social capital and economic development: Toward a theoretical synthesis and policy framework. Theory and Society, 27(2), 151-208.

Woolcock, M. (2001). The place of social capital in understanding social and economic outcomes. Isuma: Canadian Journal of Policy Research, 2(1), 11-17.

Yaril, A., Nadrian, H., Rashidian, H. Nedjat, S., Esmaeilnasab, N., Doroudi, R., \& Hoursan, H. (2013). Psychometric properties of the Persian version of the social capital questionnaire in Iran. Medical Journal of the Islamic Republic of Iran, $28(17)$. 
Table 1.

Literature table of quantitative studies involving social capital and nursing

\begin{tabular}{|c|c|c|c|c|c|}
\hline AUTHOR, COUNTRY & PURPOSE & $\begin{array}{l}\text { DESIGN } \\
\text { POPULATION } \\
\text { SAMPLE }\end{array}$ & $\begin{array}{c}\text { DEFINITION OF SOCIAL } \\
\text { CAPITAL } \\
\text { SOCIAL CAPITAL THEORY }\end{array}$ & $\begin{array}{l}\text { MEASUREMENT OF } \\
\text { SOCIAL CAPITAL }\end{array}$ & $\begin{array}{l}\text { ATTRIBUTES } \\
\text { OF SOCIAL } \\
\text { CAPITAL }\end{array}$ \\
\hline $\begin{array}{l}\text { 1. } \\
\text { Shin, Ji In \& Lee, Eunjoo. } \\
\text { (2017). The Influence of } \\
\text { Social Capital on Nurse- } \\
\text { Perceived Evidence-Based } \\
\text { Practice Implementation in } \\
\text { South Korea. Journal of } \\
\text { Nursing Scholarship. } \\
\text { 49(3):267-276 } \\
\text { doi: 10.1111/jnu.12288 } \\
\text { South Korea }\end{array}$ & $\begin{array}{l}\text { "Examine the } \\
\text { relationship between } \\
\text { evidence based } \\
\text { practice (EBP) and } \\
\text { nurses' social capital, } \\
\text { and to determine how } \\
\text { social capital affects } \\
\text { EBP adoption in } \\
\text { nurses in South } \\
\text { Korea." }\end{array}$ & $\begin{array}{l}\text { Cross sectional } \\
\text { Correlational } \\
395 \text { Nurses } \\
\text { effect } 0.2 \\
\text { power } 0.8 \\
\text { two tailed alpha } \\
0.05\end{array}$ & $\begin{array}{l}\text { "Social capital refers to the } \\
\text { trust and common values } \\
\text { formed by social relationships } \\
\text { embedded in the social } \\
\text { structure the extent of the } \\
\text { connectedness, and the quality } \\
\text { and quantity of social } \\
\text { relationships in a given } \\
\text { population." } \\
\text { Coleman } \\
\text { Granovetter/Woolcock }\end{array}$ & $\begin{array}{l}\text { Social capital outcomes } \\
\text { for nurses scale (SCON)- } \\
\mathrm{K} \\
\text { social dimensions in the } \\
\text { nursing environment }\end{array}$ & $\begin{array}{l}\text { Trust } \\
\text { Common values } \\
\text { Connectedness- } \\
\text { bonding, bridging, } \\
\text { linking } \\
\text { Quantity of social } \\
\text { relationships } \\
\text { Social Norms }\end{array}$ \\
\hline $\begin{array}{l}2 . \\
\text { Lachinger, H., Spence, K., } \\
\text { Read, E. Wilk, P. \& } \\
\text { Finegan, J. (2014). The } \\
\text { Influence of Nursing Unit } \\
\text { Empowerment } \\
\text { and Social Capital on Unit } \\
\text { Effectiveness and Nurse } \\
\text { Perceptions of Patient Care } \\
\text { Quality. Journal of } \\
\text { Nursing Administration } \\
\text { 44(6): 347-352. }\end{array}$ & $\begin{array}{l}\text { "Test a multilevel } \\
\text { model examining the } \\
\text { effects of work-unit } \\
\text { SE and social capital } \\
\text { on perceptions of unit } \\
\text { effective- ness and } \\
\text { individual nurses' } \\
\text { perceptions of patient } \\
\text { care quality on their } \\
\text { units." }\end{array}$ & Nurses & $\begin{array}{l}\text { "the sum of the actual and } \\
\text { potential resources embedded } \\
\text { within, available through, and } \\
\text { derived from the network of } \\
\text { relationships between } \\
\text { individuals and in a social } \\
\text { unit" } \\
\text { Nahapiet and Goshal's model } \\
\text { of social capital describes } \\
\text { three dimensions: structural } \\
\text { social capital, relational social }\end{array}$ & $\begin{array}{l}\text { The Shortell } \\
\text { Organizational Culture } \\
\text { Scale (SOCS) measures } \\
\text { the structural, relational, } \\
\text { and cognitive aspects of } \\
\text { social capital. Consisting } \\
\text { of } 9 \text { items rated on a 5- } \\
\text { point Likert scale ranging } \\
\text { from } 1 \text { (strongly disagree) } \\
\text { to } 5 \text { (strongly agree), an } \\
\text { average score was } \\
\text { calculated to create an } \\
\text { overall social capital }\end{array}$ & $\begin{array}{l}\text { Frequency of group } \\
\text { contact } \\
\text { Trust } \\
\text { Reciprocal interaction } \\
\text { Shared understanding }\end{array}$ \\
\hline
\end{tabular}




\begin{tabular}{|c|c|c|c|c|c|}
\hline Canada & & & $\begin{array}{l}\text { capital, and cognitive social } \\
\text { capital. }\end{array}$ & $\begin{array}{l}\text { scale. The aggregated } \\
\text { scale demonstrated a } \\
\text { Cronbach's alpha of } 0.93 \text {. }\end{array}$ & \\
\hline $\begin{array}{l}\text { 3. } \\
\text { Shin, J. \& Lee, E. (2016). } \\
\text { The effect of social capital } \\
\text { on job satisfaction and } \\
\text { quality of care among } \\
\text { hospital nurses in South } \\
\text { Korea. Journal of Nursing } \\
\text { Management, 2016, 24, } \\
\text { 934-942. } \\
\text { DOI: 10.1111/jonm.12401 } \\
\text { South Korea }\end{array}$ & $\begin{array}{l}\text { "Investigate the effect } \\
\text { of social capital on } \\
\text { workplace outcomes, } \\
\text { such as nurses' job } \\
\text { satisfaction and self- } \\
\text { reported QOC } \\
\text { measure (quality of } \\
\text { care)." }\end{array}$ & Nurses & $\begin{array}{l}\text { "Social capital is defined as } \\
\text { the sum of the actual and } \\
\text { potential resources derived } \\
\text { from the network of } \\
\text { relationships possessed by a } \\
\text { social unit." } \\
\text { Nahapiet \& Ghoshal, } 1998\end{array}$ & $\begin{array}{l}\text { The Social Capital } \\
\text { Outcomes for Nurses } \\
\text { (SCON)K. The SCON is } \\
\text { composed of } 36 \text { items and } \\
5 \text { subscales: Internal Trust } \\
\text { and Solidarity ( } 12 \text { items), } \\
\text { External Trust and } \\
\text { Solidarity (9 items), } \\
\text { Participation and } \\
\text { Empowerment ( } 7 \text { items), } \\
\text { Conflict ( } 5 \text { items) and } \\
\text { Social Cohesion with } \\
\text { Coworkers ( } 3 \text { items). } \\
\text { (Sheingold \& Sheingold, } \\
\text { 2013) } \\
\text { SCON Cronbach's alpha } \\
\text { is } 0.92 \text { SCON-K } \\
\text { Cronbach's alpha is } 0.90\end{array}$ & $\begin{array}{l}\text { According to Read } \\
\text { (2013), the social } \\
\text { capital of nurses } \\
\text { comprises the } \\
\text { following: (1) } \\
\text { networks of social } \\
\text { relationships at work, } \\
\text { (2) shared assets and } \\
\text { (3) shared ways of } \\
\text { knowing. } \\
\text { Trust } \\
\text { Participation } \\
\text { Empowerment } \\
\text { Conflict } \\
\text { Social Cohesion }\end{array}$ \\
\hline $\begin{array}{l}4 . \\
\text { Stromgren, M., Eriksson } \\
\text { A., David Bergman, D, \& } \\
\text { Dellve, L.(2016) Social } \\
\text { capital among healthcare } \\
\text { professionals: A } \\
\text { prospective study of its } \\
\text { importance for job } \\
\text { satisfaction, work } \\
\text { engagement and } \\
\text { engagement in clinical } \\
\text { improvements. }\end{array}$ & $\begin{array}{l}\text { "Assess the } \\
\text { importance of social } \\
\text { capital for job } \\
\text { satisfaction, work } \\
\text { engagement and } \\
\text { engagement in clinical } \\
\text { improvements among } \\
\text { healthcare } \\
\text { professionals." } \\
\text { "address the question } \\
\text { of whether changed }\end{array}$ & $\begin{array}{l}224 \text { MDs } \\
381 \text { RNs } \\
233 \text { assistant } \\
\text { nurses } \\
16 \text { health care } \\
\text { workers }\end{array}$ & $\begin{array}{l}\text { "Social capital is defined in } \\
\text { this study as relational within } \\
\text { an organizational setting." } \\
\text { Community and individual } \\
\text { implications } \\
\text { "Social capital is envisioned } \\
\text { as a resource springing from } \\
\text { social relationships and as an } \\
\text { investment in relationships }\end{array}$ & $\begin{array}{l}\text { Social capital is measured } \\
\text { via indices from the } \\
\text { COPSOQ II involving } \\
\text { mutual trust and } \\
\text { recognition between } \\
\text { employees and } \\
\text { management. } \\
\text { Items included from } \\
\text { COPSOQ II: } \\
\text { 1. Index from the Modern } \\
\text { Work Life Questionnaire }\end{array}$ & $\begin{array}{l}\text { Trust } \\
\text { Reciprocity } \\
\text { Social network } \\
\text { Recognition }\end{array}$ \\
\hline
\end{tabular}




\begin{tabular}{|c|c|c|c|c|c|}
\hline $\begin{array}{l}\text { International Journal of } \\
\text { Nursing Studies } 53 \text { (2016) } \\
116-125 \\
\text { Sweden }\end{array}$ & $\begin{array}{l}\text { magnitude of social } \\
\text { capital predicts } \\
\text { changed magnitude of } \\
\text { job satisfaction, work } \\
\text { engagement and } \\
\text { engagement in clinical } \\
\text { improvements." }\end{array}$ & & $\begin{array}{l}\text { with expectations of future } \\
\text { returns." } \\
\text { Putnam, Bourdieu, Coleman, } \\
\text { Nahapiet and Ghoshal }\end{array}$ & $\begin{array}{l}\text { consisting of } 3 \text { times to } \\
\text { measure reciprocity } \\
\text { Cronbach's alpha } 0.89 \\
\text { (Oxenstierna et al., 2008) } \\
\text { 2. Trust regarding } \\
\text { management was asses } \\
\text { via } 2 \text { indicators } \\
\text { 3. Mutual trust between } \\
\text { employees } \\
\text { 4. Recognition was } \\
\text { assessed via } 3 \text { indicators } \\
\text { Cronbach's alpha } 0.82 \\
\text { Social capital ranking was } \\
\text { determined by the sum of } \\
\text { reciprocity, trust } \\
\text { regarding management, } \\
\text { mutual trust between } \\
\text { employees, and } \\
\text { recognition. Items were } \\
\text { initially scored on a five- } \\
\text { grade scale and then } \\
\text { recalculated along a } \\
\text { continuum from } 0-100 \\
\text { points. } \\
\text { Cronbach's alpha } 0.73\end{array}$ & \\
\hline $\begin{array}{l}5 . \\
\text { Anderson, L., Poulsen, } \\
\text { O.M., Sundstrup, E., } \\
\text { Brandt, M., Jay, K., } \\
\text { Clausen, T. Borg, V., } \\
\text { Persson, R., \& Jakobsen, } \\
\text { M.(2015). Effect of } \\
\text { physical exercise on } \\
\text { workplace social capital: } \\
\text { Cluster randomized } \\
\end{array}$ & $\begin{array}{l}\text { "Investigate the effect } \\
\text { of physical exercise on } \\
\text { workplace social } \\
\text { capital in terms of } \\
\text { bonding, bridging and } \\
\text { linking in female } \\
\text { nurses and nursing } \\
\text { assistants." }\end{array}$ & $\begin{array}{l}\text { Female nurses and } \\
\text { nurse's aids }\end{array}$ & $\begin{array}{l}\text { Social capital is as informal } \\
\text { social networks(shared norms } \\
\text { and values) that facilitate } \\
\text { cooperation. } \\
\text { Network-based } \\
\text { This study has adopted } \\
\text { perspectives on social capital } \\
\text { shared by the Organization for }\end{array}$ & $\begin{array}{l}\text { Social capital is measured } \\
\text { via a four-dimensional } \\
\text { questionnaire developed } \\
\text { and validated by Borg et } \\
\text { al. The instrument is only } \\
\text { available in Danish. (Borg } \\
\text { V, Mateu NC and Clausen } \\
\text { T. Udvikling af en ny } \\
\text { metode til undersøgelse af } \\
\text { social kapital på }\end{array}$ & $\begin{array}{l}\text { Shared Norms and } \\
\text { Values } \\
\text { Social Networks } \\
\text { Bonding, bridging, } \\
\text { linking }\end{array}$ \\
\hline
\end{tabular}




\begin{tabular}{|c|c|c|c|c|c|}
\hline $\begin{array}{l}\text { controlled trial. } \\
\text { Scandinavian Journal of } \\
\text { Public Health, 2015; } 43 \text { : } \\
\text { 810-818 } \\
\text { Denmark }\end{array}$ & & & $\begin{array}{l}\text { Economic Cooperation and } \\
\text { Development (OECD). } \\
\text { Bonding, Bridging, and } \\
\text { Linking } \\
\text { Putnam and Woolcock }\end{array}$ & $\begin{array}{l}\text { arbejdspladsen. } \\
\text { Copenhagen: The } \\
\text { National research Centre } \\
\text { for the Working } \\
\text { Environment, 2014.) }\end{array}$ & \\
\hline $\begin{array}{l}6 . \\
\text { Sheingold, B.H. \& } \\
\text { Sheingold, S.H. (2013). } \\
\text { Using a social capital } \\
\text { framework to enhance } \\
\text { measurement of the } \\
\text { nursing work environment } \\
\text { Journal of Nursing } \\
\text { Management, 2013, 21, } \\
\text { 790-801 } \\
\text { USA }\end{array}$ & $\begin{array}{l}\text { "Develop, field test } \\
\text { and analyze } \\
\text { a social capital survey } \\
\text { instrument for } \\
\text { measuring } \\
\text { the nursing work } \\
\text { environment." }\end{array}$ & Nurses & $\begin{array}{l}\text { The World Bank has } \\
\text { conceptualized social capital } \\
\text { via bonding, bridging, and } \\
\text { linking (Grootaert et al. 2004). } \\
\text { Network based } \\
\text { Woolcock } \\
\text { "Implications for nursing } \\
\text { management social } \\
\text { capital measurement of the } \\
\text { nurse work environment has } \\
\text { the potential to provide } \\
\text { managers with an enhanced } \\
\text { set of tools for building } \\
\text { productive capacity in health- } \\
\text { care organizations and } \\
\text { achieving desired outcomes." }\end{array}$ & $\begin{array}{l}\text { Social Capital Outcome } \\
\text { for Nurses Scale (SCON) } \\
\text { Application of the World } \\
\text { Bank's Social Capital } \\
\text { Integrated Questionnaire } \\
\text { (SC-IQ) for the nursing } \\
\text { work environment } \\
\text { The final version of the } \\
\text { SCON: } \\
44 \text { social capital } \\
\text { questions, five-point } \\
\text { Likert scale, ranging from } \\
\text { strongly disagree to } \\
\text { strongly agree: } \\
\text { External Trust, Solidarity } \\
\text { and Empowerment } \\
\text { Participation and } \\
\text { Affiliation } \\
\text { Internal Trust, Solidarity } \\
\text { and } \\
\text { Harmony } \\
\text { Social Cohesion with Co- } \\
\text { workers } \\
\text { Conflict } \\
\text { Cronbach's alpha was } \\
0.92\end{array}$ & $\begin{array}{l}\text { Six dimensions of the } \\
\text { World Bank SC-IQ: } \\
\text { Networks } \\
\text { Trust and Solidarity } \\
\text { Collective Action and } \\
\text { Cooperation } \\
\text { Information and } \\
\text { Communication } \\
\text { Social Cohesion and } \\
\text { Inclusion } \\
\text { Empowerment and } \\
\text { Political Action }\end{array}$ \\
\hline
\end{tabular}




\begin{tabular}{|c|c|c|c|c|c|}
\hline $\begin{array}{l}7 . \\
\text { Nyqvist, F., Cattan, M., } \\
\text { Andersson, L., Forsman, } \\
\text { A.K., \& Gustafson, } \\
\text { Y.(2013). Social } \\
\text { Capital and Loneliness } \\
\text { Among the Very Old } \\
\text { Living at Home and in } \\
\text { Institutional Settings: A } \\
\text { Comparative Study. } \\
\text { Journal of Aging and } \\
\text { Health. 25(6) p 1013-1035 } \\
\text { DOI: } \\
\text { 10.1177/089826431349750 } \\
8\end{array}$ & $\begin{array}{l}\text { "investigate the } \\
\text { association between } \\
\text { aspects of social } \\
\text { capital and loneliness } \\
\text { among the very old } \\
\text { living at home and in } \\
\text { institutional settings." }\end{array}$ & $>85$ years old & $\begin{array}{l}\text { Putnam defines social capital } \\
\text { as "features of social } \\
\text { organization, such as trust, } \\
\text { norms and networks, that can } \\
\text { improve the efficiency of } \\
\text { society by facilitating } \\
\text { coordinated actions." } \\
\text { Social capital incorporates } \\
\text { structural (quantity) and } \\
\text { cognitive aspects (quality) of } \\
\text { resources. }\end{array}$ & $\begin{array}{l}\text { Structural Indicators: } \\
\text { Having children (yes, no) } \\
\text { respondents' living } \\
\text { situation (living together } \\
\text { with someone [spouse, } \\
\text { children/grandchildren, } \\
\text { other], alone) } \\
\text { Cognitive Indicators: } \\
\text { Having a good friend to } \\
\text { talk to when needed (yes, } \\
\text { no) } \\
\text { Perception of frequency } \\
\text { of social contacts }\end{array}$ & $\begin{array}{l}\text { Trust } \\
\text { Social Norms } \\
\text { Social Networks }\end{array}$ \\
\hline Sweden & & & & & \\
\hline $\begin{array}{l}8 . \\
\text { Kowalski, C., Driller, E., } \\
\text { Ernstmann N., Alich, } \\
\text { S.,Karbach, U., Ommen, } \\
\text { O.,Schulz-Nieswandt, F., } \\
\text { \& Holger Pfaff, H.(2010). } \\
\text { Associations between } \\
\text { emotional exhaustion, } \\
\text { social capital, workload, } \\
\text { and latitude in decision- } \\
\text { making among } \\
\text { professionals working with } \\
\text { people with disabilities. } \\
\text { Research in Developmental } \\
\text { Disabilities. 31(2). 470- } \\
\text { 479. } \\
\text { Germany }\end{array}$ & $\begin{array}{l}\text { "investigate the } \\
\text { associations between } \\
\text { emotional exhaustion, } \\
\text { social capital, } \\
\text { workload, and latitude } \\
\text { in decision-making } \\
\text { among German } \\
\text { professionals working } \\
\text { in the care of persons } \\
\text { with intellectual and } \\
\text { physical disabilities." }\end{array}$ & $\begin{array}{l}\text { health care workers } \\
\text { that care for adults } \\
\text { with disabilities }\end{array}$ & $\begin{array}{l}\text { An individualistic perspective } \\
\text { of social capital has been } \\
\text { proposed by Bourdieu (1986). } \\
\text { Social capital, according to } \\
\text { Bourdieu, is the 'aggregate of } \\
\text { the actual or potential } \\
\text { resources which are linked to } \\
\text { possession of a durable } \\
\text { network of more or less } \\
\text { institutionalized relationships } \\
\text { of mutual acquaintance and } \\
\text { recognition (i.e., to } \\
\text { membership in a group), } \\
\text { which provides each of its } \\
\text { members with the backing of } \\
\text { the collectively owned capital, } \\
\text { a credential which entitles } \\
\text { them to credit, in the various }\end{array}$ & $\begin{array}{l}\text { The Social Capital in } \\
\text { Organizations Variable } \\
\text { (SOCAPO) } \\
6 \text { items measuring } \\
\text { common values, } \\
\text { supportiveness, and } \\
\text { perceived mutual trust in } \\
\text { organizations. } \\
\text { Scoring SOCAPO: } \\
4 \text { potential responses per } \\
\text { item with response range } \\
\text { from } 1-4 \text {. Scores of } 6 \\
\text { items added up and } \\
\text { divided by } 6 . \\
\text { Final scores ranged from } \\
1 \text { to } 4 \text { points }\end{array}$ & $\begin{array}{l}\text { Common Values } \\
\text { Supportiveness } \\
\text { Mutual Trust }\end{array}$ \\
\hline
\end{tabular}




\begin{tabular}{|c|c|c|c|c|c|}
\hline & & & $\begin{array}{l}\text { senses of the word' (Bourdieu, } \\
\text { 1986: p. 247). } \\
\text { A collective perspective of } \\
\text { 'social capital' has been } \\
\text { proposed by Coleman: 'Unlike } \\
\text { other forms of capital, social } \\
\text { capital inheres in the structure } \\
\text { of relations between persons } \\
\text { and among persons. It is } \\
\text { lodged neither in individuals } \\
\text { nor in physical implements of } \\
\text { production' (Coleman, 1990: } \\
\text { p. 302). } \\
\text { Collective social capital can } \\
\text { be defined as a feature of } \\
\text { social systems that is able to } \\
\text { improve the health and the } \\
\text { capacity to perform of its } \\
\text { members (Janssen \& Pfaff, } \\
\text { 2005) } \\
\text { Support coping and stress } \\
\text { management. }\end{array}$ & & \\
\hline $\begin{array}{l}9 . \\
\text { Hsu,C., Chang, C., Heng- } \\
\text { Chiang, H., \& Chiang, C. } \\
\text { (2011). The relationships } \\
\text { among social capital, } \\
\text { organizational commitment } \\
\text { and customer-oriented } \\
\text { prosocial behavior of } \\
\text { hospital nurses. Journal of } \\
\text { Clinical Nursing 20(9/10): } \\
\text { 1383-1392. }\end{array}$ & $\begin{array}{l}\text { "identify three } \\
\text { dimensions of social } \\
\text { capital, examine their } \\
\text { links to organizational } \\
\text { commitment and } \\
\text { examine the role of } \\
\text { commitment in } \\
\text { shaping nurses' } \\
\text { customer-oriented } \\
\text { proclivity." }\end{array}$ & Nurses & $\begin{array}{l}\text { Social capital is defined "as a } \\
\text { set of social resources that } \\
\text { resides in interpersonal } \\
\text { relationships." } \\
\text { Nahapiet \& Ghoshal } \\
\text { Network based approach } \\
\text { 1990s- nursing started to look } \\
\text { at social capital }\end{array}$ & $\begin{array}{l}\text { Adapted measures from } \\
\text { previous studies (e.g. } \\
\text { Smith et al. 1994, } \\
\text { Bettencourt \& Brown } \\
\text { 1997, Leana \& Pil 2006, } \\
\text { Lee et al. 2006) to tap the } \\
\text { concept of each construct } \\
\text { and made necessary } \\
\text { modifications to fit the } \\
\text { context of this research. }\end{array}$ & $\begin{array}{l}\text { Social interaction } \\
\text { Trust } \\
\text { Shared Vision } \\
\text { Social Network }\end{array}$ \\
\hline
\end{tabular}




\begin{tabular}{|c|c|c|c|c|c|}
\hline $\begin{array}{l}\text { doi: } 10.1111 / \mathrm{j} .1365- \\
\text { 2702.2010.03672.x } \\
\text { Taiwan }\end{array}$ & & & $\begin{array}{l}1998 \text { East - building social } \\
\text { capital, as a public health } \\
\text { issue, is critical to improve the } \\
\text { health of residents in a } \\
\text { disadvantaged urban } \\
\text { neighborhood. } \\
1999 \text { Cowley and Billings - } \\
\text { social capital is important to } \\
\text { promoting health } \\
2004 \text { Kritsotakis \& } \\
\text { Garmanikow - SC is linked to } \\
\text { health } \\
2005 \text { Looman and Lindeke } \\
2006 \text { Looman SCS for } \\
\text { families with CSHNS } \\
2007 \text { DiCicco-Bloom et al. - } \\
\text { began the application of SC in } \\
\text { the workplace } \\
\text { 2010 Kowalski et al- social } \\
\text { capital in hospitals could be } \\
\text { regarded as a resource helping } \\
\text { nurses against their emotional } \\
\text { exhaustion. }\end{array}$ & & \\
\hline $\begin{array}{l}10 . \\
\text { Ichida, Y., Kondo, K., } \\
\text { Hirai, H., } \\
\text { Hanibuchi,Yoshikawa, G., } \\
\text { \&Murata, C. (2009). } \\
\text { Social capital, income } \\
\text { inequality and self-rated } \\
\text { health in Chita peninsula, } \\
\text { Japan: a multilevel analysis } \\
\text { of older people in } 25 \\
\text { communities. Social } \\
\text { Science \& Medicine. } 69 \\
\text { (2009) 489-499 }\end{array}$ & $\begin{array}{l}\text { investigate the linkage } \\
\text { between social capital } \\
\text { and health at the level } \\
\text { of a small area in } \\
\text { Japan, and also to } \\
\text { examine whether } \\
\text { social capital mediates } \\
\text { the relation between } \\
\text { income inequality and } \\
\text { health. }\end{array}$ & $\begin{array}{l}\text { Elders } \\
32,891 \text { elders from } \\
15 \text { municipalities }\end{array}$ & $\begin{array}{l}\text { Nan Lin, network approach of } \\
\text { social capital : The "resources } \\
\text { embedded in a social structure } \\
\text { which are accessed and/or } \\
\text { mobilized in purposive } \\
\text { actions" (Lin, 2001). }\end{array}$ & Survey & $\begin{array}{l}\text { Trust } \\
\text { Reciprocity } \\
\text { Informal socialization } \\
\text { Volunteering } \\
\text { Civic participation }\end{array}$ \\
\hline
\end{tabular}




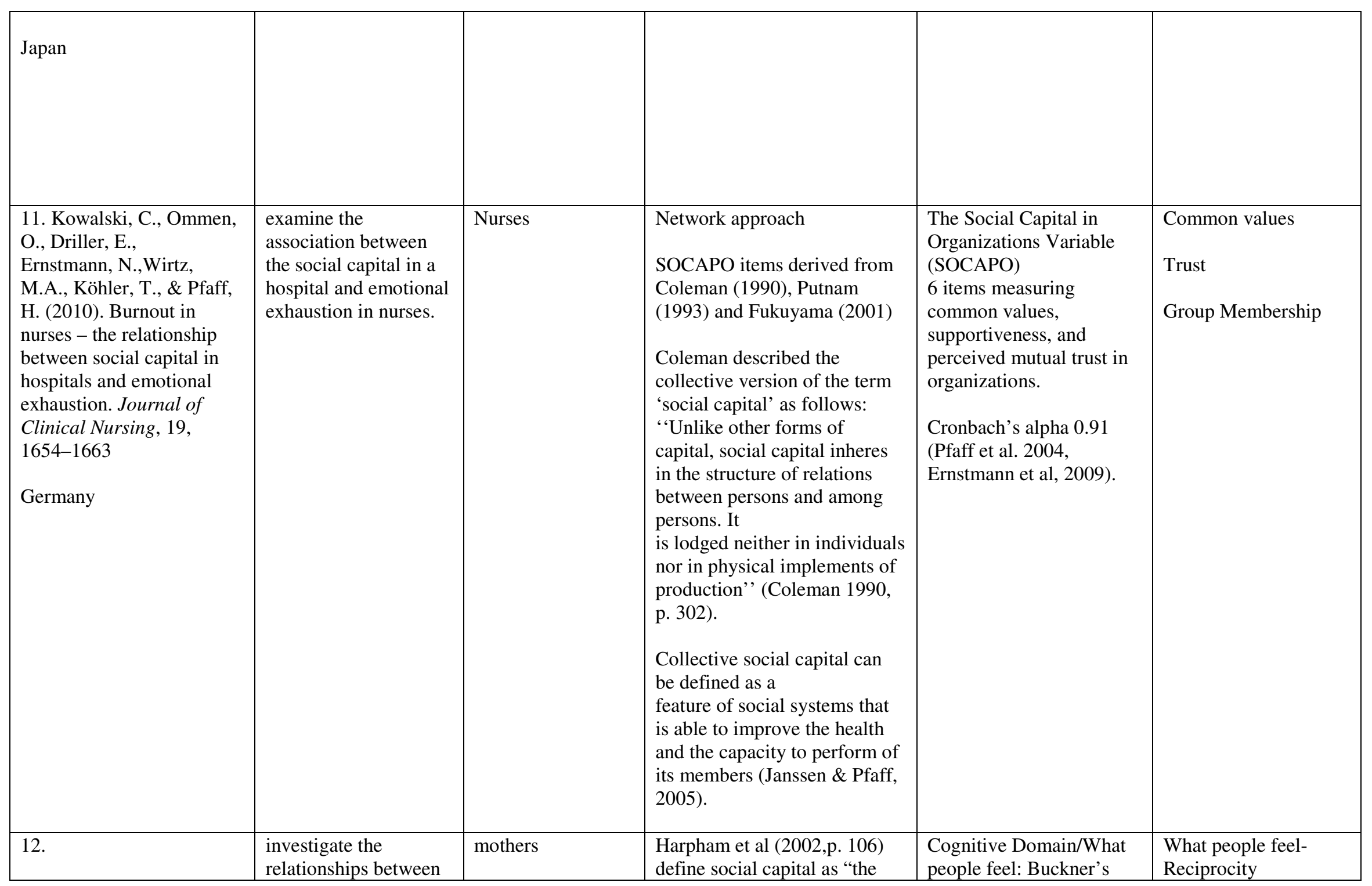




\begin{tabular}{|c|c|c|c|c|c|}
\hline $\begin{array}{l}\text { Strange, C.,Bremner, } \\
\text { A.,Fisher, C., Howat, P., \& } \\
\text { Wood, L. (2015).Mothers' } \\
\text { group participation: } \\
\text { associations with social } \\
\text { capital, social support and } \\
\text { mental well-being. Journal } \\
\text { of Advanced Nursing } \\
72(1), 85-98 . \\
\text { doi: } 10.1111 / \text { jan.12809 } \\
\text { Australia }\end{array}$ & $\begin{array}{l}\text { participation in } \\
\text { mothers' groups } \\
\text { and social capital, } \\
\text { social support and } \\
\text { mental well-being } \\
\text { measures for mothers } \\
\text { whose oldest child was } \\
0-5 \text { years }\end{array}$ & $\begin{array}{l}\text { with children aged } \\
0-5 \text { years old } \\
\text { cross sectional } \\
\text { survey }\end{array}$ & $\begin{array}{l}\text { degree of connectedness and } \\
\text { the quality and quantity of } \\
\text { social relations in a given } \\
\text { population" }\end{array}$ & $\begin{array}{l}\text { (1988) Neighbourhood } \\
\text { Cohesion Index (NCI) } \\
\text { Families, Social Capital } \\
\text { and Citizenship Survey } \\
\text { (FSCCS) (Stone \& } \\
\text { Hughes 2002). } \\
\text { Reciprocity - measured } \\
\text { incidence of } \\
\text { neighborhood residents } \\
\text { extending favors }\end{array}$ & $\begin{array}{l}\text { Shared Values } \\
\text { Trust } \\
\text { What people do - } \\
\text { participation }\end{array}$ \\
\hline $\begin{array}{l}13 . \\
\text { Pascoe, J.M., Specht, S., } \\
\text { McNicholas, C., Kasten, } \\
\text { Spears,W., \& Looman, } \\
\text { W.(2013). Correlates of } \\
\text { Mothers' Perception of } \\
\text { Their Communities' } \\
\text { Social Capital: A } \\
\text { Community-Based Study. } \\
\text { Matern Child Health J. } \\
\text { 17:1382-1390 DOI } \\
\text { 10.1007/s10995-012-1138- } \\
\text { 0 } \\
\text { USA }\end{array}$ & $\begin{array}{l}\text { document the } \\
\text { correlates of social } \\
\text { capital in a mid- } \\
\text { western community of } \\
\text { families in the United } \\
\text { States whose children } \\
\text { were being seen either } \\
\text { in their primary care } \\
\text { pediatricians' offices } \\
\text { or at a developmental } \\
\text { clinic within a } \\
\text { children's hospital to } \\
\text { refine our } \\
\text { understanding of the } \\
\text { con- text of individual } \\
\text { mother's lives that are } \\
\text { related to their } \\
\text { perception of their } \\
\text { communities' social } \\
\text { capital. }\end{array}$ & & $\begin{array}{l}\text { Szeter and Woolcock } \\
\text { =grounded theory of social } \\
\text { capital that includes domains } \\
\text { of "bonding, bridging and } \\
\text { linking social capital", } \\
\text { Health related experiences and } \\
\text { behaviors take place not } \\
\text { only at home, but in a range of } \\
\text { social situations. }\end{array}$ & $\begin{array}{l}\text { Looman's 20-item Social } \\
\text { Capital Scale (SCS)- in } \\
\text { the context of children } \\
\text { with chronic health } \\
\text { conditions. } \\
\text { Five subscales that assess } \\
\text { parent perceptions } \\
\text { regarding bonds and } \\
\text { ecological scales: } \\
\text { community involvement } \\
\text { informing/asking } \\
\text { sense of belonging } \\
\text { school connection } \\
\text { spiritual community } \\
\text { Scoring 20-100, higher } \\
\text { scores equate to more } \\
\text { social capital }\end{array}$ & $\begin{array}{l}\text { Bonding, bridging, } \\
\text { linking } \\
\text { Participation } \\
\text { Sense of belonging } \\
\text { School connection } \\
\text { Spiritual community }\end{array}$ \\
\hline $\begin{array}{l}14 . \\
\text { Moudatsou, M.M., } \\
\text { Kritsotakis, G., Alegakis, }\end{array}$ & $\begin{array}{l}\text { examine the } \\
\text { associations of social } \\
\text { capital, when }\end{array}$ & $\begin{array}{l}35-75 \text { year old } \\
\text { women }\end{array}$ & $\begin{array}{l}\text { Bourdieu 1986, Portes 1998, } \\
\text { Putnam } 2000\end{array}$ & $\begin{array}{l}\text { Social Capital } \\
\text { Questionnaire }\end{array}$ & $\begin{array}{l}\text { What people feel- } \\
\text { Trust } \\
\text { Safety }\end{array}$ \\
\hline
\end{tabular}




\begin{tabular}{|c|c|c|c|c|c|}
\hline $\begin{array}{l}\text { A.K.,Koutis, A., \& } \\
\text { Philalithis, A.E.(2014). } \\
\text { Social capital and } \\
\text { adherence to cervical and } \\
\text { breast cancer screening } \\
\text { guidelines: a cross- } \\
\text { sectional study in rural } \\
\text { Crete Health and Social } \\
\text { Care in the Community. } \\
\text { 22(4), 395-404 } \\
\text { Greece }\end{array}$ & $\begin{array}{l}\text { measured at the } \\
\text { individual level, with } \\
\text { the knowledge of } \\
\text { preventive screening } \\
\text { tests and the adherence } \\
\text { to breast and cervical } \\
\text { cancer screening } \\
\text { guidelines }\end{array}$ & & & $\begin{array}{l}\text { Adapted into Greek } \\
\text { (SCQ-G) (Onyx \& Bullen } \\
2000) \\
\text { general social capital } \\
\text { factor and } \\
\text { six domains in } 36 \\
\text { questions }\end{array}$ & $\begin{array}{l}\text { Community } \\
\text { Reciprocity } \\
\text { Social Norms } \\
\text { Social support } \\
\\
\text { What people do- } \\
\text { Participation }\end{array}$ \\
\hline $\begin{array}{l}15 . \\
\text { Oranye, N.O., Ezeah, P. \& } \\
\text { Ahmad, N.(2017). } \\
\text { Elements of Social Capital } \\
\text { and Academic } \\
\text { Performance of } \\
\text { Undergraduate Students } \\
\text { Social Indicators } \\
\text { Research. 131: 305. } \\
\text { doi:10.1007/s11205-016- } \\
\text { 1249-x } \\
\text { Canada }\end{array}$ & $\begin{array}{l}\text { answer the question on } \\
\text { whether trust in one's } \\
\text { community, belonging } \\
\text { to associations, type of } \\
\text { associations, and } \\
\text { participation in } \\
\text { campus activities were } \\
\text { associated with } \\
\text { academic } \\
\text { performance; whether } \\
\text { the norms of } \\
\text { reciprocity in the } \\
\text { community were } \\
\text { associated with } \\
\text { academic } \\
\text { performance; and to } \\
\text { determine whether the } \\
\text { degree of social } \\
\text { cohesion in the } \\
\text { community affects } \\
\text { academic } \\
\text { performance. }\end{array}$ & $\begin{array}{l}\text { Nigerian } \\
\text { undergraduate } \\
\text { students }\end{array}$ & Coleman, Kawachi & $\begin{array}{l}\text { The questionnaire was } \\
\text { validated in a small pilot } \\
\text { study, which preceded the } \\
\text { main study. Feedback } \\
\text { from lecturers and } \\
\text { students were used to } \\
\text { adapting a final set of } \\
\text { questions. Details were } \\
\text { not provided } \\
\text { The value of social capital } \\
\text { may be less about } \\
\text { empirical measurement } \\
\text { and moreso related to } \\
\text { quality of life }\end{array}$ & $\begin{array}{l}\text { Good friendships } \\
\text { Family support } \\
\text { Trust } \\
\text { Safe }\end{array}$ \\
\hline
\end{tabular}




\begin{tabular}{|c|c|c|c|c|c|}
\hline $\begin{array}{l}16 . \\
\text { Andrew, M.K. (2005). } \\
\text { Social capital, health, and } \\
\text { care home residence } \\
\text { among older adults: a } \\
\text { secondary analysis of the } \\
\text { Health Survey for England } \\
\text { 2000. Eur J Ageing 2: } 137 . \\
\text { doi:10.1007/s10433-005- } \\
0031-8 \\
\text { England }\end{array}$ & $\begin{array}{l}\text { investigate whether } \\
\text { individual-level social } \\
\text { capital is associated } \\
\text { with care home } \\
\text { residence and with } \\
\text { function, mental } \\
\text { health, and self- } \\
\text { assessed health in } \\
\text { older adults. }\end{array}$ & $\begin{array}{l}>65 \text { years old } \\
\text { Survey data } \\
\text { Secondary analysis }\end{array}$ & $\begin{array}{l}\text { Individual level - network } \\
\text { conceptualization of social } \\
\text { capital } \\
\text { Bourdieu and Putnam } \\
\text { Kawachi }\end{array}$ & $\begin{array}{l}\text { Multiple indicators: } \\
\text { Perceived social support } \\
\text { Group Participation } \\
\text { Trust and reciprocity }\end{array}$ & $\begin{array}{l}\text { Engagement } \\
\text { Trust } \\
\text { Reciprocity } \\
\text { Social support } \\
\text { Participation } \\
\text { Size of social network }\end{array}$ \\
\hline $\begin{array}{l}17 . \\
\text { Aminzadeh, K., Denny, } \\
\text { S.,Utter, J., Milfont, T.L., } \\
\text { Ameratunga, S., Teevale, } \\
\text { T., \& Clark, T. (2013). } \\
\text { Neighbourhood social } \\
\text { capital and adolescent } \\
\text { self-reported wellbeing in } \\
\text { New Zealand: A } \\
\text { multilevel analysis. Social } \\
\text { Science \& Medicine } 84 \\
\text { 13-21 } \\
\text { New Zealand }\end{array}$ & $\begin{array}{l}\text { Employ a multilevel } \\
\text { approach to examine } \\
\text { the independent } \\
\text { association between } \\
\text { New Zealand } \\
\text { adolescent wellbeing } \\
\text { and indicators of their } \\
\text { neighborhood social } \\
\text { capital measured } \\
\text { based on adolescents' } \\
\text { perception and } \\
\text { participation in their } \\
\text { neighborhood. } \\
\text { Explore the interaction } \\
\text { between neighborhood } \\
\text { social capital, } \\
\text { adolescent wellbeing } \\
\text { and individual } \\
\text { socioeconomic status. }\end{array}$ & Adolescents & $\begin{array}{l}\text { Community Level } \\
\text { Kawachi and Woolcock }\end{array}$ & $\begin{array}{l}\text { WHO-5 Wellbeing Index } \\
\text { Measured student mood } \\
\text { and life satisfaction } \\
\text { Neighborhood Social } \\
\text { Capital: } \\
5 \text { indicators" } \\
\text { Physical disintegration, } \\
\text { Membership in } \\
\text { community organizations } \\
\text { Residential stability } \\
\text { Neighborhood social } \\
\text { cohesion Facilities } \\
\text { Randomized, multilevel } \\
\text { models that controlled for } \\
\text { student age, sex, ethnicity } \\
\text { and socio- economic } \\
\text { status. Schools and } \\
\text { neighborhoods were } \\
\text { treated as random effects. }\end{array}$ & $\begin{array}{l}\text { Trust } \\
\text { Reciprocity } \\
\text { Sense of Community } \\
\text { Group membership } \\
\text { Bonding, bridging, } \\
\text { linking } \\
\text { Neighborhood } \\
\text { characteristics }\end{array}$ \\
\hline 18. & $\begin{array}{l}\text { examined the } \\
\text { association between }\end{array}$ & $\begin{array}{l}516 \text { adults } \\
\text { mean age } 51.7\end{array}$ & Putnam & Structural social capital: & $\begin{array}{l}\text { Structural social } \\
\text { capital- Membership }\end{array}$ \\
\hline
\end{tabular}




\begin{tabular}{|c|c|c|c|c|c|}
\hline $\begin{array}{l}\text { Kido, Y., Kawakami, N., } \\
\text { Miyamoto, Y., Chiba, R., } \\
\text { \& Tsuchiya, M. (2013). } \\
\text { Social Capital and Stigma } \\
\text { Toward People with } \\
\text { Mental Illness in Tokyo, } \\
\text { Japan. Community Ment } \\
\text { Health J. 49:243-247 } \\
\text { DOI 10.1007/s10597-012- } \\
\text { 9548-4 } \\
\text { Japan }\end{array}$ & $\begin{array}{l}\text { area- and individual- } \\
\text { based social capital } \\
\text { and stigma towards } \\
\text { people with mental } \\
\text { illness among } \\
\text { community residents } \\
\text { of } 20 \\
\text { cities/municipalities of } \\
\text { Tokyo, Japan }\end{array}$ & & $\begin{array}{l}\text { Uphoff defines social capital } \\
\text { as consisting of structural and } \\
\text { cognitive domains. } \\
\text { Structural social capital } \\
\text { consists of relationship, } \\
\text { networks, associations, and } \\
\text { institutional structures that } \\
\text { link people and groups } \\
\text { together. } \\
\text { Cognitive social capital } \\
\text { consists of values, norms, } \\
\text { reciprocity, altruism, and civic } \\
\text { responsibility. }\end{array}$ & $\begin{array}{l}1 \text { item that evaluated } \\
\text { participation in voluntary } \\
\text { organizations. } \\
\text { Cognitive social capital } \\
\text { was measured by four } \\
\text { items. }\end{array}$ & $\begin{array}{l}\text { in social networks that } \\
\text { link people together } \\
\text { Cognitive social } \\
\text { capital- } \\
\text { Values } \\
\text { Norms } \\
\text { Reciprocity } \\
\text { Altruism } \\
\text { Civic responsibility }\end{array}$ \\
\hline $\begin{array}{l}19 . \\
\text { Lee, C. (2013). Social } \\
\text { capital and relational } \\
\text { coordination in outpatient } \\
\text { clinics: An } \\
\text { interprofessional analysis } \\
\text { Journal of } \\
\text { Interprofessional Care. } 27 \text { : } \\
81-87 \\
\text { USA }\end{array}$ & $\begin{array}{l}\text { examine the } \\
\text { association between } \\
\text { social capital and } \\
\text { relational coordination } \\
\text { in order to validate the } \\
\text { specific relational } \\
\text { attributes that } \\
\text { influence informal } \\
\text { coordination. }\end{array}$ & $\begin{array}{l}\text { Cross- sectional } \\
342 \text { MDs and RNs } \\
\text { in outpatient clinics }\end{array}$ & $\begin{array}{l}\text { (Nahapiet \& Ghoshal, 1998). } \\
\text { Bourdieu- social capital is "the } \\
\text { aggregate of the actual or } \\
\text { potential resources which are } \\
\text { linked to possession of a } \\
\text { durable network of more or } \\
\text { less institutionalized relation- } \\
\text { ships of mutual acquaintance } \\
\text { and recognition" } \\
\text { Relational coordination: } \\
\text { "informal coordination } \\
\text { reinforced by communication } \\
\text { and supportive relationships" }\end{array}$ & $\begin{array}{l}\text { Social capital was } \\
\text { measured via three } \\
\text { dimensions: } \\
\text { structural } \\
\text { relational } \\
\text { cognitive }\end{array}$ & \\
\hline $\begin{array}{l}20 . \\
\text { Wahl, A., Berglund, A., \& } \\
\text { Loyland, B. (2010). Is } \\
\text { social capital associated } \\
\text { with coping, self-esteem, } \\
\text { health and quality of life in }\end{array}$ & $\begin{array}{l}\text { explore the relation- } \\
\text { ships between social } \\
\text { capital, coping, self- } \\
\text { esteem, health and } \\
\text { quality of life in a } \\
\text { sample of people }\end{array}$ & $\begin{array}{l}\text { Adults who receive } \\
\text { social assistance }\end{array}$ & $\begin{array}{l}\text { Putman Social Capital: } \\
\text { Interpersonal trust } \\
\text { Norms of reciprocity } \\
\text { Social engagement }\end{array}$ & $\begin{array}{l}\text { The interpersonal trust } \\
\text { aspect of social capital is } \\
\text { the focus of this study } \\
\text { Three questions regarding } \\
\text { generalized trust in others }\end{array}$ & $\begin{array}{l}\text { Trust } \\
\text { Norms of Reciprocity } \\
\text { Participation }\end{array}$ \\
\hline
\end{tabular}




\begin{tabular}{|c|c|c|c|c|c|}
\hline $\begin{array}{l}\text { long-term social assistance } \\
\text { recipients? Scand J Caring } \\
\text { Sci; 2010; 24; 808-816 } \\
\text { Scandinavian Journal of } \\
\text { Caring Sciences. } \\
\text { doi: } 10.1111 / \mathrm{j} .1471 \text { - } \\
6712.2010 .00779 . \mathrm{x} \\
\text { Norway }\end{array}$ & $\begin{array}{l}\text { receiving social } \\
\text { assistance, living in } \\
\text { various municipalities } \\
\text { in Norway. }\end{array}$ & & & $\begin{array}{l}\text { 1. Trustworthiness of } \\
\text { others. } \\
\text { 2. Honesty of others } \\
\text { 3. Helping behaviors of } \\
\text { others. } \\
\text { Answers are scored on a } \\
0-10 \text { scale. Higher scores } \\
\text { equate to higher level of } \\
\text { trust. } \\
\text { Cronbach alpha is } 0.83\end{array}$ & \\
\hline $\begin{array}{l}21 . \\
\text { Duke, N.M., Skay, C.L., } \\
\text { Pettingell, S.L., \& } \\
\text { Borowsky, I.W. (2009). } \\
\text { From Adolescent } \\
\text { Connections to Social } \\
\text { Capital: Predictors of } \\
\text { Civic Engagement in } \\
\text { Young Adulthood } \\
\text { Journal of Adolescent } \\
\text { Health } 44 \text { 161-168 } \\
\text { USA }\end{array}$ & $\begin{array}{l}\text { examine the ability of } \\
\text { adolescent connection } \\
\text { in family and } \\
\text { community contexts to } \\
\text { promote an aspect of } \\
\text { healthy youth } \\
\text { development and } \\
\text { transition into } \\
\text { adulthood, civic } \\
\text { engagement. }\end{array}$ & $\begin{array}{l}18-26 \text { year olds } \\
9130 \text { young adults } \\
\text { in all }\end{array}$ & $\begin{array}{l}\text { Resiliency framework } \\
\text { Putnam }\end{array}$ & $\begin{array}{l}\text { Wave 1: influence of } \\
\text { connection in family and } \\
\text { community contexts } \\
\text { Wave 3: outcomes of } \\
\text { civic engagement in } \\
\text { young adulthood }\end{array}$ & $\begin{array}{l}\text { Social bonding } \\
\text { Family connections } \\
\text { Engagement }\end{array}$ \\
\hline $\begin{array}{l}22 . \\
\text { Caperchionea, Lauderb, } \\
\text { C.W., Koltc, G.S., } \\
\text { Duncana. M.J., \& } \\
\text { Mummerya, W. K.(2008). } \\
\text { Associations between } \\
\text { social capital and health } \\
\text { status in an Australian } \\
\text { population. Psychology, } \\
\text { Health \& Medicine. Vol. } \\
\text { 13, No. 4, 471-482 }\end{array}$ & $\begin{array}{l}\text { investigate the } \\
\text { association between } \\
\text { social capital and } \\
\text { health related quality } \\
\text { of life in a sample of } \\
\text { Australian adults }\end{array}$ & Adults & Kawachi & $\begin{array}{l}\text { British General } \\
\text { Household Survey of } \\
\text { Social Capital Module } \\
\text { (Coulthard, Walker, \& } \\
\text { Morgan, 2001) } \\
9 \text { items pertaining to } 5 \\
\text { domains of social capital }\end{array}$ & $\begin{array}{l}\text { Networks } \\
\text { Social Norms } \\
\text { Trust } \\
\text { Reciprocity }\end{array}$ \\
\hline
\end{tabular}




\begin{tabular}{|c|c|c|c|c|c|}
\hline Australia & & & & $\begin{array}{l}\text { Scored from } 0-21 \text {, higher } \\
\text { number equates to higher } \\
\text { level of social capital }\end{array}$ & \\
\hline $\begin{array}{l}23 . \\
\text { Farag, A., Blegen, M., } \\
\text { Gedney-Lose, A. Lose, D., } \\
\text { \& Perkhounkova, Y. } \\
\text { (2017) Voluntary } \\
\text { Medication Error } \\
\text { Reporting by ED Nurses: } \\
\text { Examining the Association } \\
\text { with Work Environment } \\
\text { and Social Capital Journal } \\
\text { of Emergency Nursing. } \\
\text { Volume 43, Issue 3, } \\
\text { USA }\end{array}$ & $\begin{array}{l}\text { examine the } \\
\text { relationship among } \\
\text { work environment } \\
\text { (nurse manager } \\
\text { leadership style and } \\
\text { safety climate), social } \\
\text { capital (warmth and } \\
\text { belonging } \\
\text { relationships and } \\
\text { organizational trust), } \\
\text { and nurses' } \\
\text { willingness to report } \\
\text { medication errors. }\end{array}$ & $\begin{array}{l}71 \text { emergency } \\
\text { nurses }\end{array}$ & Not clearly identified & $\begin{array}{l}\text { Cook and Wall } \\
\text { Organizational Trust } \\
\text { Survey: organizational } \\
\text { trust } \\
\text { Modified Litwin and } \\
\text { Stringer Organizational } \\
\text { Climate Survey 2: } \\
\text { Warmth and belonging }\end{array}$ & $\begin{array}{l}\text { Warmth } \\
\text { Belonging } \\
\text { Trust }\end{array}$ \\
\hline
\end{tabular}




\begin{tabular}{|c|c|c|c|c|c|}
\hline $\begin{array}{l}25 . \\
\text { Fujita, S., Kawakami,N. } \\
\text { Ando, E., Inoue, A.,Tsuno, } \\
\text { K., Kurioka, S.,PhD, \& } \\
\text { Kawachi, I. (2016). The } \\
\text { Association of Workplace } \\
\text { Social Capital with Work } \\
\text { Engagement of Employees } \\
\text { in Health Care Settings: A } \\
\text { Multilevel Cross-Sectional } \\
\text { Analysis. Journal of } \\
\text { Occupations and } \\
\text { Environmental Medicine. } \\
\text { Volume 58, Number } 3 \\
\text { Japan }\end{array}$ & $\begin{array}{l}\text { examine the cross- } \\
\text { sectional multilevel } \\
\text { association between } \\
\text { unit-level workplace } \\
\text { social capital and } \\
\text { individual-level work } \\
\text { engagement among } \\
\text { employees in health } \\
\text { care settings }\end{array}$ & adults & $\begin{array}{l}\text { Kawachi and Berkman- how } \\
\text { social capital influences } \\
\text { individual health: } \\
\text { 1. more efficient diffusion of } \\
\text { knowledge on health } \\
\text { promotion } \\
\text { 2. maintenance of healthy } \\
\text { behavioral norms through } \\
\text { informal social control } \\
\text { 3. promotion of access to local } \\
\text { services and amenities } \\
\text { 4. psychological processes that } \\
\text { provide effective support and } \\
\text { mutual respect }\end{array}$ & $\begin{array}{l}\text { Japanese version of } \\
\text { Workplace Social Capital } \\
\text { Scale. } \\
\text { Eight measured on a five- } \\
\text { point Likert (1 to 5) scale. }\end{array}$ & $\begin{array}{l}\text { Acceptance } \\
\text { Work engagement }\end{array}$ \\
\hline $\begin{array}{l}26 . \\
\text { Papastavrou, E.,Andreou, } \\
\text { P., Middleton, N., } \\
\text { Tsangari, H., \&Papacostas, } \\
\text { S. (2015).Dementia } \\
\text { caregiver burden } \\
\text { association with } \\
\text { community participation } \\
\text { aspect of social capital. } \\
\text { Journal of Advanced } \\
\text { Nursing } 71(12), 2898-2910 \\
\text { DOI: 10.1111/jan.12762 } \\
\text { Greece }\end{array}$ & $\begin{array}{l}\text { explore the burden of } \\
\text { caregivers of people } \\
\text { with dementia and } \\
\text { depression in the } \\
\text { context of social } \\
\text { capital in the Greek } \\
\text { Cypriot population }\end{array}$ & $\begin{array}{l}\text { Adult caregivers of } \\
\text { adults with } \\
\text { dementia }\end{array}$ & $\begin{array}{l}\text { Lewis et al. (2012) social } \\
\text { capital framework for } \\
\text { pallitative care. } \\
4 \text { areas of facilitation: } \\
\text { 1. advocacy and support for } \\
\text { closed networks and relations } \\
\text { 2. foster intra-community } \\
\text { formal and informal networks } \\
\text { and relations } \\
\text { 3. connect with inter- } \\
\text { community networks } \\
\text { 4. drive linkages with } \\
\text { government institutions and } \\
\text { organizations } \\
\text { Bourdieu, Putnam, Woolcock }\end{array}$ & $\begin{array}{l}\text { Social Capital } \\
\text { Questionnaire-Greek } \\
\text { version (SCQ-G) } \\
\text { Originally developed in } \\
\text { New South Wales, } \\
\text { Australia (Onyx \& Bullen } \\
2000 \text { ) } \\
\text { SCQ comprises of } 36 \\
\text { items } \\
\text { 4-point Likert-type scale } \\
\text { score range from 36-144, } \\
\text { higher score equates to } \\
\text { greater amount of social } \\
\text { capital }\end{array}$ & $\begin{array}{l}\text { Social Networks } \\
\text { Social Norms } \\
\text { Trust } \\
\text { Connections } \\
\text { Participation/engagem } \\
\text { ent }\end{array}$ \\
\hline
\end{tabular}




\begin{tabular}{|c|c|c|c|c|c|}
\hline $\begin{array}{l}27 . \\
\text { Ernstmann, N., Ommen,O. } \\
\text { Driller, E., Kowalski, C., } \\
\text { Neumann, M., } \\
\text { Bartholomeyczik, S., \& } \\
\text { Pfaff, H.(2009). Social } \\
\text { Capital and Risk } \\
\text { Management in Nursing. } \\
\text { Journal of Nursing Care } \\
\text { Quality. Vol. 24, No. 4, pp. } \\
\text { 340-347 } \\
\text { Germany }\end{array}$ & $\begin{array}{l}\text { examine the } \\
\text { relationship between } \\
\text { social capital and } \\
\text { clinical risk } \\
\text { management in } \\
\text { hospitals from nurses' } \\
\text { perspective. }\end{array}$ & $\begin{array}{l}\text { Nurses, } \\
\text { administrative } \\
\text { staff, clinicians, } \\
\text { technical } \\
\text { employees } \\
\mathrm{N}=2644\end{array}$ & $\begin{array}{l}\text { Fukuyama perspective- } \\
\text { Social capital is generated } \\
\text { from internalized, informal } \\
\text { standards within an } \\
\text { organization and produces } \\
\text { cooperation. } \\
\text { Social capital is as a way of } \\
\text { solving collective problems } \\
\text { through a sense of community } \\
\text { and trust. }\end{array}$ & $\begin{array}{l}\text { Social Capital in } \\
\text { Hospitals Variable: } \\
\text { common values in } \\
\text { hospital } \\
\text { perceived trust in hospital } \\
\text { Cronbach Alpha } 0.91 \\
\text { Choice of } 4 \text { responses: } \\
\text { with } 1 \text { being a low level } \\
\text { of disagree to } 4 \text { high level } \\
\text { of agree }\end{array}$ & $\begin{array}{l}\text { Trust } \\
\text { Common Values } \\
\text { Reciprocity }\end{array}$ \\
\hline $\begin{array}{l}28 . \\
\text { Moore, S., Daniel, M., } \\
\text { Paquet, C. Laurette, Dube, } \\
\text { L., \& Gauvin, } \\
\text { L.(2009).Association of } \\
\text { individual network social } \\
\text { capital with abdominal } \\
\text { adiposity, overweight and } \\
\text { obesity. Journal of Public } \\
\text { Health. Vol. 31, No. 1, pp. } \\
\text { 175-183 } \\
\text { Canada }\end{array}$ & $\begin{array}{l}\text { hypothesized that } \\
\text { higher individual } \\
\text { social capital would be } \\
\text { associated with having } \\
\text { WC and BMI below } \\
\text { at-risk levels. } \\
\text { hypothesized that a } \\
\text { network measure } \\
\text { would have greater } \\
\text { content validity than } \\
\text { proxy measures in } \\
\text { representing social } \\
\text { connectivity and } \\
\text { resource access, and } \\
\text { would be most } \\
\text { strongly associated } \\
\text { with overweight and } \\
\text { obesity }\end{array}$ & Adults & $\begin{array}{l}\text { Network approach } \\
\text { Bourdieu }\end{array}$ & $\begin{array}{l}\text { Social capital was } \\
\text { measured via a position } \\
\text { generator by assessing } \\
\text { ties to persons in specific } \\
\text { occupations } \\
3 \text { Indices of social capital: } \\
\text { upper reachability } \\
\text { diversity } \\
\text { range }\end{array}$ & $\begin{array}{l}\text { Bonding, bridging, } \\
\text { linking } \\
\text { Trust } \\
\text { Participation } \\
\text { Cohesion }\end{array}$ \\
\hline
\end{tabular}




\begin{tabular}{|c|c|c|c|c|c|}
\hline $\begin{array}{l}29 . \\
\text { Farahbod, A., } \\
\text { Goudarzvand Chegini, M., } \\
\text { KouchakinejadEramsadati, } \\
\text { L., \& Mohtasham-Amiri, } \\
\text { Z. (2015).The Association } \\
\text { between Social Capital and } \\
\text { Burnout in Nurses of a } \\
\text { Trauma Referral Teaching } \\
\text { Hospital. Acta Medica } \\
\text { Iranica, 53(4):214-219. } \\
\text { Iran }\end{array}$ & $\begin{array}{l}\text { evaluate and assess the } \\
\text { dimensions of social } \\
\text { capital and their } \\
\text { association with } \\
\text { burnout to finally } \\
\text { promote health in } \\
\text { nurses, patients, and } \\
\text { the whole society }\end{array}$ & Nurses & $\begin{array}{l}\text { Unclear theoretical } \\
\text { underpinnings }\end{array}$ & $\begin{array}{l}\text { This study uses a social } \\
\text { capital questionnaire } \\
\text { extracted from a study by } \\
\text { Boyas and colleagues in } \\
2012\end{array}$ & \\
\hline $\begin{array}{l}30 . \\
\text { Kritsotakis, G., Chatzi, L., } \\
\text { Maria Vassilaki, } \\
\text { M.,Georgiou, V., } \\
\text { Kogevinas, M., Philalithis, } \\
\text { A.E., and Koutis, A. } \\
\text { (2015).Social capital, } \\
\text { tolerance of diversity and } \\
\text { adherence to } \\
\text { Mediterranean diet: the } \\
\text { Rhea Mother-Child Cohort } \\
\text { in Crete, Greece. Public } \\
\text { Health Nutrition: 18(7), } \\
\text { 1300-1307 } \\
\text { Greece }\end{array}$ & $\begin{array}{l}\text { estimate the } \\
\text { associations of } \\
\text { individual maternal } \\
\text { social capital and its } \\
\text { subscales with } \\
\text { adherence to the } \\
\text { Mediterranean diet } \\
\text { during pregnancy. }\end{array}$ & Pregnant women & $\begin{array}{l}\text { Social capital: cognitive and } \\
\text { structural. } \\
\text { Cognitive social capital refers } \\
\text { to how people feel (trust, } \\
\text { reciprocity, tolerance) } \\
\\
\text { Structural social capital } \\
\text { explores what people a do } \\
\text { (behaviors in their } \\
\text { environment, participation, } \\
\text { networks). }\end{array}$ & $\begin{array}{l}\text { Social Capital } \\
\text { Questionnaire- Greek } \\
\text { version } \\
\text { A general Total Social } \\
\text { Capital factor } \\
\text { Six domains, } 36 \\
\text { questions: } \\
\text { Participation in the Local } \\
\text { Community } \\
\text { Feelings of Safety } \\
\text { Family/Friends } \\
\text { Connections } \\
\text { Value of Life and Social } \\
\text { Agency } \\
\text { Tolerance of Diversity } \\
\text { Work Connections } \\
\text { Higher scores on a 4-point } \\
\text { Likert- type scale indicate } \\
\text { more social capital. }\end{array}$ & $\begin{array}{l}\text { Cognitive social } \\
\text { capital refers to } \\
\text { perceptions, beliefs } \\
\text { and feelings = trust, } \\
\text { reciprocity, tolerance } \\
\text { Structural social } \\
\text { capital explores what } \\
\text { people actually do and } \\
\text { how they behave in } \\
\text { their social } \\
\text { environment = } \\
\text { participation, networks }\end{array}$ \\
\hline
\end{tabular}




\begin{tabular}{|c|c|c|c|c|c|}
\hline $\begin{array}{l}31 . \\
\text { Webel AR, Wantland D, } \\
\text { Rose CD, Kemppainen J, } \\
\text { Holzemer WL, Chen WT, } \\
\text { Johnson MO, Nicholas P, } \\
\text { Eller LS, Chaiphibalsarisdi } \\
\text { P, Sefcik E, Nokes K, } \\
\text { Corless IB, Tyer-Viola L, } \\
\text { Kirksey K, Voss J, } \\
\text { Sullivan K, Rivero- } \\
\text { Méndez M, Brion J, } \\
\text { Iipinge S, Phillips JC, } \\
\text { Portillo C. (2015). A } \\
\text { Cross-Sectional } \\
\text { Relationship Between } \\
\text { Social Capital, Self- } \\
\text { Compassion, and } \\
\text { Perceived HIV Symptoms } \\
\text { Journal of pain and } \\
\text { symptom } \\
\text { management;50(1):59-68. } \\
\text { USA }\end{array}$ & $\begin{array}{l}\text { extend the previous } \\
\text { literature by } \\
\text { examining the } \\
\text { relationship between } \\
\text { self-compassion and } \\
\text { social capital and its } \\
\text { impact on the current } \\
\text { HIV symptom } \\
\text { experience in adult } \\
\text { PLWH }\end{array}$ & Adult PLWH & $\begin{array}{l}\text { Social capital is the } \\
\text { "aggregate of potential } \\
\text { resources, which are linked to } \\
\text { possession of a durable } \\
\text { network of more or less } \\
\text { institutionalized relationships } \\
\text { of mutual acquaintance or } \\
\text { recognition"” }\end{array}$ & $\begin{array}{l}\text { Social Capital Scale } \\
\text { (Onyx \& Bullen 2000) } \\
\text { Used } 31 \text { of the } 36 \text { items }(8 \\
\text { subscales) } \\
\text { participation in the local } \\
\text { community } \\
\text { social agency } \\
\text { feelings of trust and safety } \\
\text { neighborhood connections } \\
\text { friends and family } \\
\text { connections tolerance of } \\
\text { diversity } \\
\text { value of life } \\
\text { workplace connections }\end{array}$ & $\begin{array}{l}\text { Participation } \\
\text { Trust } \\
\text { Connection } \\
\text { Value of Life } \\
\text { Tolerance of diversity }\end{array}$ \\
\hline $\begin{array}{l}32 . \\
\text { Kritsotakis, G.,Vassilaki, } \\
\text { M., Melaki, V., Georgiou, } \\
\text { V.,Philalithis, A.E., } \\
\text { Bitsios,P. Kogevinas, M., } \\
\text { Chatzi, L., \& Koutis, A. } \\
\text { (2013). Social capital in } \\
\text { pregnancy and postpartum } \\
\text { depressive symptoms: A } \\
\text { prospective mother-child } \\
\text { cohort study (the Rhea } \\
\text { study). International }\end{array}$ & $\begin{array}{l}\text { estimate prospectively } \\
\text { the effect of } \\
\text { individual-level self- } \\
\text { reported maternal } \\
\text { social capital during } \\
\text { pregnancy on } \\
\text { postpartum depressive } \\
\text { symptoms, measured } \\
\text { by the Edinburgh } \\
\text { Postpartum } \\
\text { Depression Scale } \\
\text { (EPDS), in singleton }\end{array}$ & Pregnant women & $\begin{array}{l}\text { Bourdeui, Putnam, Kawachi- } \\
\text { combined approaches }\end{array}$ & $\begin{array}{l}\text { Social Capital Scale- } \\
\text { Greek Version } \\
\text { general social capital } \\
\text { factor and } \\
36 \text { questions, } 6 \text { domains } \\
4 \text { point Likert scale, } \\
\text { higher score equates to } \\
\text { higher social capital } \\
\text { Based off of the Social } \\
\text { Capital Questionnaire }\end{array}$ & $\begin{array}{l}\text { Cognitive - what } \\
\text { people feel } \\
\text { Structural - what } \\
\text { people do }\end{array}$ \\
\hline
\end{tabular}




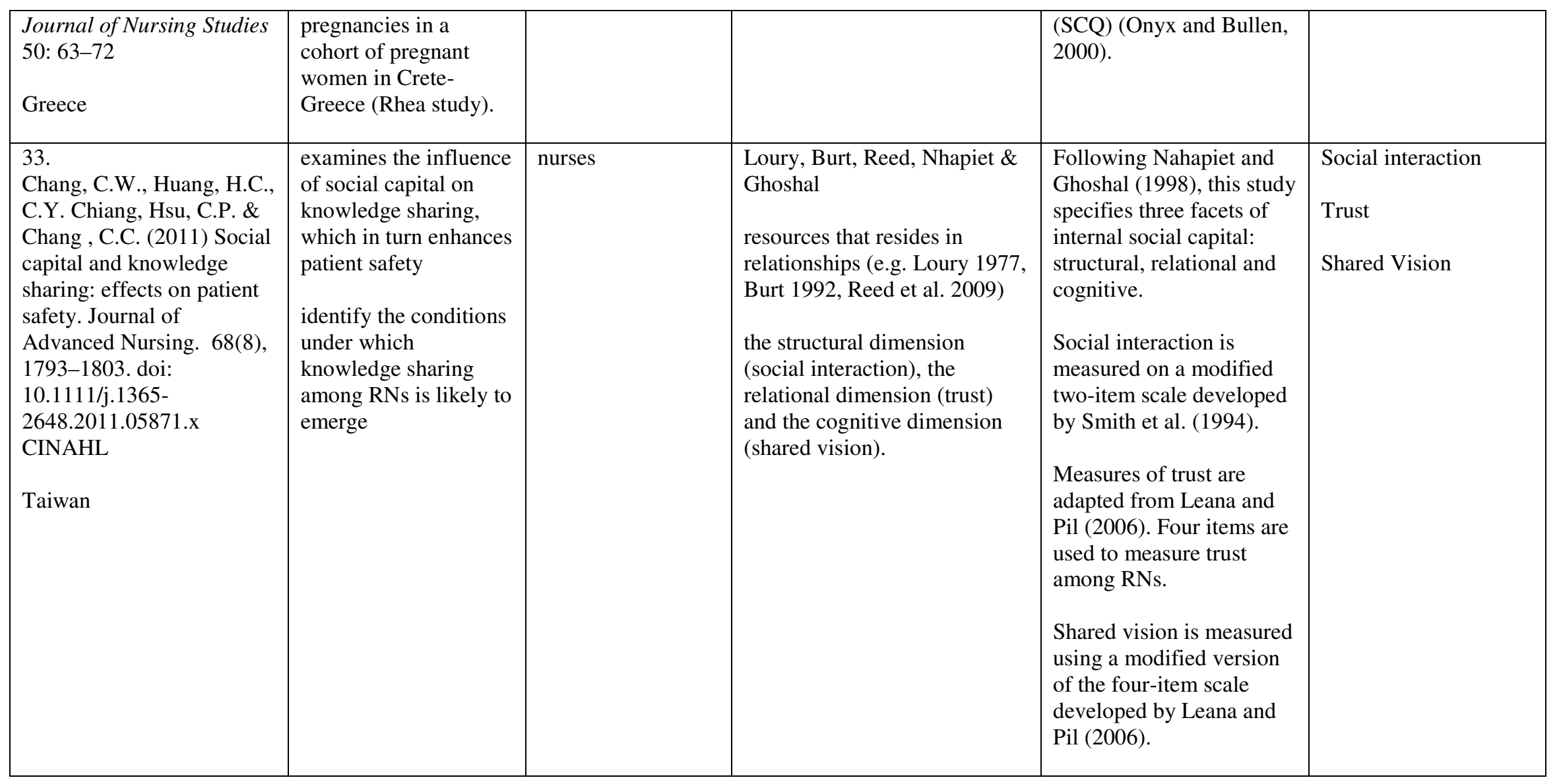


Table 2.

Framework/Conceptual Analysis papers involving social capital and nursing $(n=23)$ bolded article titles indicate pediatric content

\begin{tabular}{|c|c|c|c|c|}
\hline AUTHOR, COUNTRY & PURPOSE & $\begin{array}{c}\text { DEFINITION OF SOCIAL } \\
\text { CAPITAL } \\
\text { SOCIAL CAPITAL THEORY }\end{array}$ & RECOMMENDATIONS & ATTRIBUTES \\
\hline $\begin{array}{l}\text { 1. } \\
\text { Plunkett, R, Leipert, B, } \\
\text { \& Olson, J. (2015). } \\
\text { Exploring the Influence } \\
\text { of Social Determinants, } \\
\text { Social Capital, and } \\
\text { Health Expertise on } \\
\text { Health and the Rural } \\
\text { Church. Journal of } \\
\text { Holistic Nursing. 34(3) } \\
\text { 236-243. Doi } \\
\text { 10.1177/089801011560 } \\
\text { 5231 } \\
\text { Canada }\end{array}$ & $\begin{array}{l}\text { "explore health } \\
\text { influences emerging } \\
\text { from rural churches } \\
\text { using social } \\
\text { determinants of health, } \\
\text { social capital, and } \\
\text { health expertise." }\end{array}$ & $\begin{array}{l}\text { "Rankin (2002) describes social } \\
\text { capital as associations formed } \\
\text { of reciprocal norms and } \\
\text { expressions of trust. Thus, it } \\
\text { does not belong to any } \\
\text { individual but rather is } \\
\text { embedded in relationships } \\
\text { between individuals." } \\
\text { And in communities } \\
\text { Kawachi, Putnam, Bourdieu }\end{array}$ & $\begin{array}{l}\text { Higher levels of social capital are } \\
\text { associated with health benefits. } \\
\text { Social capital may have utility in } \\
\text { improving health outcomes in } \\
\text { rural communities. } \\
\text { "individuals living within a social } \\
\text { structure with a high degree of } \\
\text { social capital often experience } \\
\text { greater health benefits than those } \\
\text { belonging to social structures } \\
\text { with lower levels of social capital. } \\
\text { These benefits come regardless of } \\
\text { the individual's contribution to } \\
\text { the network (Kawachi et al., } \\
\text { 2008)." } \\
\text { "Social capital can shape } \\
\text { individual health through the } \\
\text { maintenance of healthy } \\
\text { behavioral norms through }\end{array}$ & $\begin{array}{l}\text { Shared trust } \\
\text { Reciprocity } \\
\text { Social Norms } \\
\text { Informal social control } \\
\text { Bonding, bridging, } \\
\text { linking }\end{array}$ \\
\hline
\end{tabular}




\begin{tabular}{|c|c|c|c|c|}
\hline & & & $\begin{array}{l}\text { informal social control (Kawachi } \\
\text { \& Berkman, 2000)." }\end{array}$ & \\
\hline $\begin{array}{l}2 . \\
\text { Hean, S, Hewitt- } \\
\text { Taylor, J., Cash, } \\
\text { M., Buckley, H. \& van } \\
\text { Teijlingen, E. (2013). } \\
\text { A nurse's role in } \\
\text { promoting social } \\
\text { capital in children and } \\
\text { young people. } \\
\text { Nursing Children \& } \\
\text { Young People. 25(1): } \\
\text { 19-23. } \\
\text { England }\end{array}$ & $\begin{array}{l}\text { "present the concept } \\
\text { of social capital as a } \\
\text { cognitive tool to help } \\
\text { nurses reflect on why } \\
\text { and how supporting } \\
\text { these networks is } \\
\text { important." }\end{array}$ & $\begin{array}{l}\text { The 'social' component of } \\
\text { social capital is defined as the } \\
\text { quality, quantity and context of } \\
\text { relationships formed in a } \\
\text { network } \\
\text { The 'capital' component of } \\
\text { social capital is defined as the } \\
\text { compound effect of } \\
\text { membership within a social } \\
\text { network. }\end{array}$ & $\begin{array}{l}\text { Membership within a functional } \\
\text { family network, enables children } \\
\text { to access skills and emotional } \\
\text { support from family members. } \\
\text { "Not all children will have access } \\
\text { to a family network, or one with } \\
\text { appropriate resources. This may } \\
\text { create cycles of disadvantage that } \\
\text { can span generations. However, } \\
\text { these cycles can be broken } \\
\text { if network functioning is } \\
\text { enhanced or children are able to } \\
\text { access alternative networks, such } \\
\text { as community groups, from } \\
\text { which these advantages can be } \\
\text { accrued." }\end{array}$ & $\begin{array}{l}\text { Interpersonal trust } \\
\text { Generalized trust } \\
\text { Internal and external } \\
\text { resources } \\
\text { Social norms } \\
\text { Social networks- } \\
\text { membership, location } \\
\text { of members, } \\
\text { heterogeneity (ethnic } \\
\text { or cultural mix), and } \\
\text { gender composition. } \\
\text { Bonding, bridging, } \\
\text { linking }\end{array}$ \\
\hline $\begin{array}{l}3 . \\
\text { Brown, B. (2015). } \\
\text { Towards a critical } \\
\text { understanding of } \\
\text { mutuality in mental } \\
\text { healthcare: } \\
\text { relationships, power } \\
\text { and social capital } \\
\text { Journal of Psychiatric } \\
\text { and Mental Health }\end{array}$ & $\begin{array}{l}\text { "explores the } \\
\text { neglected notion of } \\
\text { mutuality in the } \\
\text { context of mental } \\
\text { healthcare." }\end{array}$ & $\begin{array}{l}\text { "social capital involves } \\
\text { connections with others and the } \\
\text { participants deriving mutual } \\
\text { benefit from these } \\
\text { connections." } \\
\text { As Winter (2000, p. } 24) \\
\text { reminds us, this is because } \\
\text { 'social capital is a social }\end{array}$ & $\begin{array}{l}\text { "Within the sociological tradition } \\
\text { the key thinkers of social capital - } \\
\text { Pierre Bourdieu (1986), James } \\
\text { Coleman (1990) and Robert } \\
\text { Putnam (2000) - all emphasize } \\
\text { the importance of social networks } \\
\text { and relationships in affording } \\
\text { mutuality." }\end{array}$ & $\begin{array}{l}\text { Mutual reciprocal } \\
\text { relationships } \\
\text { Trust } \\
\text { Social Norms } \\
\text { Obligation } \\
\text { Sanctions }\end{array}$ \\
\hline
\end{tabular}




\begin{tabular}{|c|c|c|c|c|}
\hline $\begin{array}{l}\text { Nursing. 22(10), 829- } \\
835 . \\
\text { England }\end{array}$ & & $\begin{array}{l}\text { product demanding social } \\
\text { interaction'. } \\
\text { "Social capital is the aggregate } \\
\text { of the actual and potential } \\
\text { resources which are linked to } \\
\text { possession of a durable network } \\
\text { of more or less institutionalized } \\
\text { relationships of mutual } \\
\text { acquaintance and recognition - } \\
\text { or in other words, membership } \\
\text { in a group." (Bourdieu 1986, p. } \\
249 \text { ). } \\
\text { As Winter (2000, p. 24) } \\
\text { reminds us, this is because } \\
\text { 'social capital is a social } \\
\text { product demanding social } \\
\text { interaction'. } \\
\text { Bourdieu, Coleman, Putnam }\end{array}$ & $\begin{array}{l}\text { The resources conferred by social } \\
\text { capital are only attainable via } \\
\text { membership and recognition } \\
\text { within a social network. }\end{array}$ & \\
\hline $\begin{array}{l}4 . \\
\text { Taylor, R. (2012). } \\
\text { Social capital and the } \\
\text { nursing student } \\
\text { experience. Nurse } \\
\text { Education Today. 32: } \\
\text { 250-254 } \\
\text { England }\end{array}$ & $\begin{array}{l}\text { "presents an argument } \\
\text { that the development } \\
\text { of social capital for } \\
\text { individual students } \\
\text { and the wider } \\
\text { university community, } \\
\text { enhances the student } \\
\text { experience and } \\
\text { facilitates success." }\end{array}$ & $\begin{array}{l}\text { "Features of social life - } \\
\text { networks, norms and trust - that } \\
\text { enable participants to act } \\
\text { together more effectively to } \\
\text { pursue shared objectives" } \\
\text { Putnam }\end{array}$ & $\begin{array}{l}\text { "Social capital may benefit } \\
\text { individuals, the community } \\
\text { and/or wider society and is } \\
\text { inherent within the relationships } \\
\text { that people have rather than } \\
\text { economic capital which can be } \\
\text { seen through people's bank } \\
\text { accounts." (Portes, 1998). }\end{array}$ & $\begin{array}{l}\text { Social networks } \\
\text { Social Norms } \\
\text { Trust } \\
\text { Participation } \\
\text { Strong and weak links }\end{array}$ \\
\hline
\end{tabular}




\begin{tabular}{|c|c|c|c|c|}
\hline & & & $\begin{array}{l}\text { Development of social capital is a } \\
\text { good thing for the experience of } \\
\text { student nurses. } \\
\text { "Social capital can be generated } \\
\text { through the use of policy } \\
\text { interventions designed to increase } \\
\text { the likelihood that people will } \\
\text { connect in relevant areas." }\end{array}$ & \\
\hline $\begin{array}{l}\text { 5. } \\
\text { Drevdahl, D., Kneipp, } \\
\text { SM, Canales, MK, \& } \\
\text { Dorcy, KS (2001). } \\
\text { Reinvesting in Social } \\
\text { Justice: A Capital Idea } \\
\text { for Public Health } \\
\text { Nursing? Advances in } \\
\text { Nursing Science. 24(2): } \\
\text { 19-31. }\end{array}$ & $\begin{array}{l}\text { "explore social justice } \\
\text { and social capital in } \\
\text { nursing" }\end{array}$ & $\begin{array}{l}\text { "The aggregate of the actual or } \\
\text { potential resources which are } \\
\text { linked to possession of a } \\
\text { durable network of more or less } \\
\text { institutionalized relationships of } \\
\text { mutual acquaintance or } \\
\text { recognition." } \\
\text { Bourdieu } \\
\text { "individual motivations } \\
\text { embody both economic and } \\
\text { social interests." } \\
\text { Coleman } \\
\text { Social capital has increasingly } \\
\text { emerged in the public health } \\
\text { literature as not only a } \\
\text { determinant of health, but also a } \\
\text { mediator of socioeconomic } \\
\text { status and health, and a } \\
\text { promising concept for } \\
\text { developing community (or } \\
\text { population- based) } \\
\text { interventions to diminish or }\end{array}$ & $\begin{array}{l}\text { "The development of social } \\
\text { policies directed at decreasing } \\
\text { material and social disparities that } \\
\text { will have any meaningful effect } \\
\text { on reducing or eliminating health } \\
\text { disparities, rather than promoting } \\
\text { social capital, cohesion, or trust in } \\
\text { communities who understand } \\
\text { first-hand the tyranny of the } \\
\text { market and its negative social } \\
\text { consequences." } \\
\text { "Given the state of the nation in } \\
\text { terms of widening in- come } \\
\text { inequalities and the consequences } \\
\text { that surround it (including moral } \\
\text { and health dimensions), public } \\
\text { health scholars are searching for } \\
\text { novel approaches to repair the } \\
\text { damage incurred to the health of } \\
\text { the nation's impoverished } \\
\text { communities. One such approach } \\
\text { is founded on the concept of } \\
\text { social capital." }\end{array}$ & $\begin{array}{l}\text { Reciprocity } \\
\text { Norms } \\
\text { Trust }\end{array}$ \\
\hline
\end{tabular}




\begin{tabular}{|c|c|c|c|c|}
\hline & & $\begin{array}{l}\text { eliminate disparities of all } \\
\text { kinds. }\end{array}$ & $\begin{array}{l}\text { "public health nurses must be } \\
\text { wary of uncritically adopting } \\
\text { social capital as a panacea for } \\
\text { inequalities as advocating for } \\
\text { interventions seeking to build } \\
\text { social capital may be as harmful } \\
\text { as inequities themselves." } \\
\text { The assumption that individuals } \\
\text { act as free agents in all encounters } \\
\text { is grounded in exchange theory } \\
\text { and serves as the foundation for a } \\
\text { capitalist market based economy. } \\
\text { Is the concept of social capital } \\
\text { literally grounded within market } \\
\text { ideology? } \\
\text { "the development of social } \\
\text { policies directed at decreasing } \\
\text { material and social disparities that } \\
\text { will have meaningful effect on } \\
\text { reducing or eliminating health } \\
\text { disparities, rather than promoting } \\
\text { social capital, cohesion, or trust in } \\
\text { communities who understand } \\
\text { first-hand the tyranny of the } \\
\text { market and its negative social } \\
\text { consequences." }\end{array}$ & \\
\hline 6. & $\begin{array}{l}\text { "examine how social } \\
\text { capital could be a }\end{array}$ & $\begin{array}{l}\text { "The concept of social capital is } \\
\text { a term coalescing around }\end{array}$ & $\begin{array}{l}\text { "Social capital is about the value } \\
\text { derived from being a member of a }\end{array}$ & \begin{tabular}{|l} 
Social Norms \\
\end{tabular} \\
\hline
\end{tabular}




\begin{tabular}{|c|c|c|c|c|}
\hline $\begin{array}{l}\text { Hofmeyer, A.T. (2013). } \\
\text { How can a social } \\
\text { capital framework } \\
\text { guide managers to } \\
\text { develop positive nurse } \\
\text { relationships and } \\
\text { patient outcomes? } \\
\text { Journal of Nursing } \\
\text { Management. 21, 782- } \\
789 \\
\text { Australia }\end{array}$ & $\begin{array}{l}\text { mediating factor } \\
\text { through which } \\
\text { managers' leadership } \\
\text { positively influences } \\
\text { relationships with } \\
\text { nurses and quality } \\
\text { patient outcomes." }\end{array}$ & $\begin{array}{l}\text { relational norms (cognitive) and } \\
\text { networks (structures) that } \\
\text { facilitate collective action for } \\
\text { mutual benefit and increased } \\
\text { productivity" } \\
\text { Putnam- bonding, bridging, } \\
\text { linking } \\
\text { Woolcock/Grootaert - World } \\
\text { Bank } \\
\text { "Cohen and Prusak (2001) } \\
\text { describe stocks of social capital } \\
\text { in organizations as 'trust, } \\
\text { mutual understanding, and } \\
\text { shared values and behaviors } \\
\text { that bind the members of } \\
\text { human networks and } \\
\text { communities and make } \\
\text { cooperative action possible." }\end{array}$ & $\begin{array}{l}\text { team, group or a network (with } \\
\text { norms of trust and cooperation) } \\
\text { that fosters information known by } \\
\text { one individual to flow to others in } \\
\text { the network" (Cohen \& Prusak } \\
\text { 2001) } \\
\text { To clarify, Portes (1998) explains } \\
\text { that 'economic capital is in } \\
\text { people's bank accounts, human } \\
\text { capital is inside their heads, and } \\
\text { social capital inheres in the } \\
\text { structure of their relationships'. }\end{array}$ & $\begin{array}{l}\text { Social Networks } \\
\text { World Bank SC-IQ: } \\
1 \text { bonding, bridging } \\
\text { and linking networks } \\
2 \text { trust } \\
3 \text { solidarity } \\
4 \text { collective action } \\
5 \text { cooperation } \\
6 \text { information and } \\
\text { communication } \\
7 \text { social cohesion } \\
8 \text { inclusion } \\
9 \text { empowerment. }\end{array}$ \\
\hline $\begin{array}{l}7 . \\
\text { Rosenberg, J. } \\
\text { P., Horsfall, } \\
\text { D., Leonard, R., } \\
\text { \&Noonan, K.(2015). } \\
\text { Informal caring } \\
\text { networks for people at } \\
\text { end of life: building } \\
\text { social capital in } \\
\text { Australian communities } \\
\text { Health Sociology }\end{array}$ & $\begin{array}{l}\text { "examination of the } \\
\text { place of social capital } \\
\text { and community } \\
\text { development in the } \\
\text { provision of end of life } \\
\text { care at home." }\end{array}$ & Putnam & $\begin{array}{l}\text { there has been a growing interest } \\
\text { in examining social capital in } \\
\text { palliative care as it applies to the } \\
\text { social networks and relationships } \\
\text { in the palliative care setting. } \\
\text { Social capital, however, is not } \\
\text { sufficient to guarantee } \\
\text { community development (Mayer } \\
\text { \& Rankin, 2002). }\end{array}$ & $\begin{array}{l}\text { Trust } \\
\text { Belongingness } \\
\text { Social Cohesion } \\
\text { Social Network } \\
\text { Access to information } \\
\text { Inclusion }\end{array}$ \\
\hline
\end{tabular}




\begin{tabular}{|c|c|c|c|c|}
\hline $\begin{array}{l}\text { Review. 24(1):29-37. } \\
\text { http://dx.doi.org/10.108 } \\
\underline{0 / 14461242.2014 .9994} \\
\underline{00} \\
\text { Australia }\end{array}$ & & & $\begin{array}{l}\text { Micro-level = bonding networks } \\
\text { provide not only resources and } \\
\text { help with daily functions but also } \\
\text { build trust and a sense of } \\
\text { belonging. } \\
\text { Meso-level = bridging networks } \\
\text { can enable access to information } \\
\text { and local services and create a } \\
\text { sense of community inclusion and } \\
\text { cohesion. } \\
\text { Macro-level,= linking networks } \\
\text { provide access to government to } \\
\text { obtain resources for the lower } \\
\text { levels, increase civic trust and } \\
\text { social cohesion, and influence } \\
\text { policy. }\end{array}$ & Civic Trust \\
\hline $\begin{array}{l}8 . \\
\text { Lloyd-Odgers, J. } \\
\text { (2005) How are the } \\
\text { concepts of social } \\
\text { capital, primary health } \\
\text { care and health } \\
\text { promotion relevant to } \\
\text { the goals and activities } \\
\text { of child and family } \\
\text { health nurses? } \\
\text { Nuritinga. 6:1-10 } \\
\text { Australia }\end{array}$ & $\begin{array}{l}\text { "define the concepts } \\
\text { of social capital, } \\
\text { primary health care, } \\
\text { and health promotion, } \\
\text { and discuss their } \\
\text { application and } \\
\text { relevance to the goals } \\
\text { and activities of child } \\
\text { and family health } \\
\text { nurses in Australia." }\end{array}$ & $\begin{array}{l}\text { "Social capital is defined as the } \\
\text { potential resource that exists } \\
\text { between people within the } \\
\text { community that can be utilized } \\
\text { for the benefit of its' members." } \\
\text { Bourdieu, Coleman, and } \\
\text { Putnam view the family as the } \\
\text { main source of social capital in } \\
\text { the community. }\end{array}$ & $\begin{array}{l}\text { Do strong families build strong } \\
\text { communities? } \\
\text { Families are the principal social } \\
\text { network and experience greater } \\
\text { participation rates - how is this } \\
\text { related to social capital? } \\
\text { What nurses do to foster social } \\
\text { capital in families: } \\
\text { 1. Social support for parents } \\
\text { 2. Alleviate parental anxiety }\end{array}$ & $\begin{array}{l}\text { Social Cohesion } \\
\text { Trust } \\
\text { Cooperation } \\
\text { Mutual Benefit } \\
\text { Bonding, bridging, } \\
\text { linking }\end{array}$ \\
\hline
\end{tabular}




\begin{tabular}{|c|c|c|c|c|}
\hline & & & $\begin{array}{l}\text { 3. Child health nurses also reduce } \\
\text { the risk of poor quality child- } \\
\text { rearing and child abuse by } \\
\text { '...defining and reinforcing } \\
\text { normative parenting practices,' } \\
\text { (Rogers and Moore 2003, p.5) } \\
\text { and reducing situational stress } \\
\text { through referral to local childcare } \\
\text { and early intervention services, } \\
\text { 4. Surveillance } \\
\text { 5. Promote nutrition } \\
\text { 6. safe nurturing environments }\end{array}$ & \\
\hline $\begin{array}{l}9 . \\
\text { Durant, T.J. (2011). } \\
\text { The Utility of } \\
\text { Vulnerability } \\
\text { and Social Capital Theo } \\
\text { ries in Studying the } \\
\text { Impact of Hurricane } \\
\text { Katrina on the Elderly. } \\
\text { Journal of Family } \\
\text { Issues. 32(10): 1285- } \\
\text { 1302. } \\
\text { DOI: } \\
\text { 10.1177/0192513X114 } \\
\text { 12491 } \\
\text { USA }\end{array}$ & $\begin{array}{l}\text { "assess the utility of } \\
\text { an integrated } \\
\text { vulnerability and } \\
\text { social capital theory } \\
\text { for enhancing our } \\
\text { understanding of the } \\
\text { impact of the } \\
\text { Hurricane Katrina } \\
\text { disaster on the elderly } \\
\text { population of New } \\
\text { Orleans, Louisiana." }\end{array}$ & $\begin{array}{l}\text { defines social capital as "social } \\
\text { networks, the reciprocities that } \\
\text { arise from them and the value } \\
\text { of these for achieving mutual } \\
\text { goals." Putnam }\end{array}$ & $\begin{array}{l}\text { "A major theoretical proposition } \\
\text { of social capital in explaining } \\
\text { responses to a disaster is that } \\
\text { social networks (relationships, } \\
\text { mutual ties, etc.) may provide } \\
\text { varying levels and types of } \\
\text { support to persons during a } \\
\text { disaster." }\end{array}$ & $\begin{array}{l}\text { Trust } \\
\text { Associations } \\
\text { Reciprocity } \\
\text { Social Networks } \\
\text { Participation } \\
\text { Mutual Goals } \\
\text { Reciprocity }\end{array}$ \\
\hline $\begin{array}{l}10 . \\
\text { Lauder, W. Reel, S., } \\
\text { Farmer, J., \& Griggs, }\end{array}$ & $\begin{array}{l}\text { "explore the } \\
\text { usefulness of social } \\
\text { capital and }\end{array}$ & $\begin{array}{l}\text { Social capital is popularly } \\
\text { defined as forms of association }\end{array}$ & $\begin{array}{l}\text { "We are in a period in which } \\
\text { social connections between }\end{array}$ & $\begin{array}{l}\text { Trust } \\
\text { Norms of Reciprocity }\end{array}$ \\
\hline
\end{tabular}




\begin{tabular}{|c|c|c|c|c|}
\hline $\begin{array}{l}\text { H. (2006). Social } \\
\text { capital, rural nursing } \\
\text { and rural nursing } \\
\text { theory. Nursing } \\
\text { Inquiry. 13(1): } 73-79 \\
\text { DOI: } 10.1111 / j .1440- \\
\text { 1800.2006.00297.x } \\
\text { England }\end{array}$ & $\begin{array}{l}\text { related theories to help } \\
\text { in understanding the } \\
\text { function of nurses in } \\
\text { rural communities." }\end{array}$ & $\begin{array}{l}\text { that express trust and norms of } \\
\text { reciprocity. } \\
\text { Putnam, Coleman and Bourdieu } \\
\text { differ in their detailed } \\
\text { conceptions of social capital, } \\
\text { although all believe there is } \\
\text { value in exploring 'capital' as a } \\
\text { vehicle to solve community } \\
\text { problems collaboratively and } \\
\text { promote healthy and poverty- } \\
\text { free communities. } \\
\text { World Bank }\end{array}$ & $\begin{array}{l}\text { health professionals and their } \\
\text { patients are being replaced by } \\
\text { economic, administrative and } \\
\text { technological solutions and where } \\
\text { supportive networks are actively } \\
\text { devalued by some practices } \\
\text { central to many modern } \\
\text { organizations (Edmondson, } \\
\text { 2003)." } \\
\text { "The multifaceted role of nursing } \\
\text { professionals in rural } \\
\text { communities needs to be properly } \\
\text { accounted for in examining the } \\
\text { social context of health and health } \\
\text { service access, as well as in } \\
\text { evaluating services." } \\
\text { Nurses have unparalleled } \\
\text { knowledge of providing health- } \\
\text { care to the poor and socially } \\
\text { excluded (Russell and Neff-Smith } \\
\text { 2003) }\end{array}$ & \\
\hline $\begin{array}{l}11 . \\
\text { Looman, W.S. \& } \\
\text { Lindecke, L.L. (2005). } \\
\text { Health and social } \\
\text { context: Social capital's } \\
\text { utility as a construct for } \\
\text { nursing and health } \\
\text { promotion. Journal of } \\
\text { Pediatric Health Care. } \\
\text { 19(2): 90-94 }\end{array}$ & $\begin{array}{l}\text { Explore the utility of } \\
\text { social capital as a } \\
\text { construct for nursing } \\
\text { health promotion }\end{array}$ & $\begin{array}{l}\text { "an asset that yields benefits in } \\
\text { the future consistent with the } \\
\text { level of investment made in the } \\
\text { present." } \\
\text { "social capital refers to social } \\
\text { networks, norms of reciprocity, } \\
\text { mutual assistance, and } \\
\text { trustworthiness." }\end{array}$ & $\begin{array}{l}\text { "Social capital is a mechanism by } \\
\text { which existing resources may be } \\
\text { mobilized by and from the people, } \\
\text { not for them. It may represent } \\
\text { away for nurses to add a social } \\
\text { context to health assessments." } \\
\text { Consider the social-relational } \\
\text { aspects of health }\end{array}$ & $\begin{array}{l}\text { Social Networks } \\
\text { Norms of Reciprocity } \\
\text { Mutual Assistance } \\
\text { Trustworthiness }\end{array}$ \\
\hline
\end{tabular}




\begin{tabular}{|c|c|c|c|c|}
\hline United States & & Putnam & $\begin{array}{l}\text { Strategies for nurses to } \\
\text { incorporate social capital into the } \\
\text { clinical setting: } \\
\text { 1. Create Opportunities for } \\
\text { Networking } \\
\text { 2. Diffuse Knowledge } \\
\text { 3. Build Personal Social Capital } \\
\text { 4. Practice "Vision Therapy" }\end{array}$ & \\
\hline $\begin{array}{l}12 . \\
\text { Kritsotakis, G. \& } \\
\text { Gamarnikow, E. } \\
\text { (2004). What is social } \\
\text { capital and how does it } \\
\text { relate to health? } \\
\text { International Journal of } \\
\text { Nursing Studies } 41 \text { 43- } \\
50 \\
\text { Greece }\end{array}$ & $\begin{array}{l}\text { Following an analysis } \\
\text { of theoretical issues } \\
\text { surrounding social } \\
\text { capital and social } \\
\text { support, recent } \\
\text { research is used to } \\
\text { illustrate how these } \\
\text { are affecting health. It } \\
\text { is argued that more } \\
\text { theoretical } \\
\text { development is needed } \\
\text { before social capital } \\
\text { can be used to form a } \\
\text { new community } \\
\text { nursing practice. }\end{array}$ & $\begin{array}{l}\text { Loury (1977) used this term, he } \\
\text { defined it as: the set of } \\
\text { resources that inhere in family } \\
\text { relations and in community } \\
\text { social organizations and that are } \\
\text { useful for the cognitive or the } \\
\text { social development of a child or } \\
\text { a young person. } \\
\text { World Bank social capital is the } \\
\text { 'glue that holds society } \\
\text { together' } \\
\text { Social support refers to } \\
\text { relations a person develops in } \\
\text { his/her social environment, } \\
\text { while social capital breaks } \\
\text { away from this individualistic } \\
\text { approach to address more } \\
\text { effectively the influence of the } \\
\text { society to the individual. } \\
\text { Woolcock Grootaert, }\end{array}$ & $\begin{array}{l}\text { the ideas of social capital (social } \\
\text { contact, companionship, etc.) may } \\
\text { guide our mode of operation } \\
\text { during nursing interventions. } \\
\text { "in the level of nursing policy, we } \\
\text { should be concerned 'not how to } \\
\text { care for those whom we know } \\
\text { (our neighbourly civil society } \\
\text { obligations), but those whom we } \\
\text { do not (the thousands of } \\
\text { anonymous others with whom we } \\
\text { share our cities, states and } \\
\text { planet)' (Labonte, 1999, p. 431)." }\end{array}$ & $\begin{array}{l}\text { Trust } \\
\text { Social Support }\end{array}$ \\
\hline
\end{tabular}




\begin{tabular}{|c|c|c|c|c|}
\hline $\begin{array}{l}13 . \\
\text { Bernosky de Flores, } \\
\text { C.H.(2010). } \\
\text { A Conceptual } \\
\text { Framework for the } \\
\text { Study of Social Capital } \\
\text { in New Destination } \\
\text { Immigrant } \\
\text { Communities. Journal } \\
\text { of Transcultural } \\
\text { Nursing. 21(3) 205-211 } \\
\text { DOI: } \\
\text { 10.1177/104365960935 } \\
8783\end{array}$ & $\begin{array}{l}\text { a conceptual } \\
\text { framework drawn } \\
\text { from social capital } \\
\text { theory to study the } \\
\text { approaches } \\
\text { immigrants use to } \\
\text { access health-related } \\
\text { resources in new } \\
\text { destination } \\
\text { communities. }\end{array}$ & $\begin{array}{l}\text { Social capital is not social } \\
\text { support. Rather, it is a means } \\
\text { for gaining access to social } \\
\text { support. Human capital is used } \\
\text { to create social capital through } \\
\text { giving, exchanging, and sharing } \\
\text { human capital and other } \\
\text { resources within the context of } \\
\text { relationships. } \\
\text { Portes's (1998) definition of } \\
\text { social capital is his emphasis on } \\
\text { the individual's capacity to } \\
\text { access resources by virtue of } \\
\text { membership in networks and } \\
\text { other social structures rather } \\
\text { than the actual resources } \\
\text { themselves (p. 6). He also } \\
\text { describes the different } \\
\text { approaches individuals and } \\
\text { groups use to create and access } \\
\text { social capital such as } \\
\text { reciprocity, altruism, bonded } \\
\text { solidarity, and enforceable trust } \\
\text { (Portes, 2000). } \\
\text { social capital also consists of } \\
\text { the resources communities } \\
\text { create or acquire through } \\
\text { collective human action. } \\
\text { Putnam }\end{array}$ & $\begin{array}{l}\text { Nurse participation in political } \\
\text { activities that address health } \\
\text { disparities and underserved } \\
\text { populations can increase and } \\
\text { strengthen the capacity of a } \\
\text { community to manage health } \\
\text { needs (Sistrom \& Hale, 2006). } \\
\text { Created a framework from a } \\
\text { review of the social, economics, } \\
\text { and health sciences literature that } \\
\text { addressed social capital as a } \\
\text { theory, a concept, and a variable } \\
\text { These are human capital, personal } \\
\text { networks, social capital, and } \\
\text { resources. } \\
\text { Community health nurses (Lloyd- } \\
\text { Odgers, 2005) have described } \\
\text { direct and indirect nursing } \\
\text { interventions that may facilitate } \\
\text { the creation of social capital for } \\
\text { individual clients and their } \\
\text { families. } \\
\text { Nurses agree that our current } \\
\text { understanding of social capital as } \\
\text { a theory, as a concept, and as a } \\
\text { variable lacks clarification and } \\
\text { depth and requires development } \\
\text { and refinement for application in } \\
\text { nursing research, education, and } \\
\text { clinical settings (Carlson \& } \\
\text { Chamberlain, 2003; Gopee, 2002; }\end{array}$ & $\begin{array}{l}\text { Reciprocity } \\
\text { Altruism } \\
\text { Sharing } \\
\text { Solidarity } \\
\text { Trust } \\
\text { Collective Action }\end{array}$ \\
\hline
\end{tabular}




\begin{tabular}{|c|c|c|c|c|}
\hline & & & $\begin{array}{l}\text { Lloyd-Odgers, 2005; Looman \& } \\
\text { Lindeke, 2005; Norris \& Roulier, } \\
\text { 2002). }\end{array}$ & \\
\hline $\begin{array}{l}14 . \\
\text { Cannuscio, C., Block, } \\
\text { J., \& Kawachi, I. } \\
\text { (2003).Social Capital } \\
\text { and Successful Aging: } \\
\text { The Role of Senior } \\
\text { Housing. Ann Intern } \\
\text { Med. 2003;139:395- } \\
\text { 399. }\end{array}$ & $\begin{array}{l}\text { discuss the } \\
\text { implications of the } \\
\text { long- term trends in } \\
\text { social capital for } \\
\text { successful aging in } \\
\text { U.S. society, as well } \\
\text { as potential solutions } \\
\text { for "building" social } \\
\text { capital in the } \\
\text { community, } \\
\text { specifically through } \\
\text { examples of options } \\
\text { for senior housing. }\end{array}$ & $\begin{array}{l}\text { Social capital can be defined } \\
\text { broadly as the resources } \\
\text { available to individuals and } \\
\text { groups through their social } \\
\text { connections to their } \\
\text { communities } \\
\text { Putnam }\end{array}$ & $\begin{array}{l}\text { Social capital, however, is neither } \\
\text { a panacea for public health nor a } \\
\text { concept that can be easily } \\
\text { translated into a recipe for } \\
\text { successful aging. } \\
\text { we develop further in the } \\
\text { following case study, is the } \\
\text { individual who may lack social } \\
\text { ties and social support on a } \\
\text { personal level but nevertheless } \\
\text { benefits from residing within a } \\
\text { community that is rich in social } \\
\text { connections. }\end{array}$ & $\begin{array}{l}\text { Civic Engagement } \\
\text { Participation } \\
\text { Social connections } \\
\text { Trust } \\
\text { Social Norms } \\
\text { Mutual Aid }\end{array}$ \\
\hline $\begin{array}{l}15 . \\
\text { Hofmeyer, A. \& } \\
\text { Marck, P.B. (2008). } \\
\text { Building social capital } \\
\text { in healthcare } \\
\text { organizations: Thinking } \\
\text { ecologically for safer } \\
\text { care. Nursing Outlook. } \\
\text { 56:145-151 }\end{array}$ & $\begin{array}{l}\text { Can a sound } \\
\text { ecological } \\
\text { understanding of } \\
\text { social capital guide } \\
\text { our research, } \\
\text { leadership, and } \\
\text { practice- and how? }\end{array}$ & $\begin{array}{l}\text { Cohen and Prusak describe } \\
\text { social capital in organizations } \\
\text { as "trust, mutual understanding, } \\
\text { and shared values and } \\
\text { behaviors that bind the } \\
\text { members of human networks } \\
\text { and communities and make } \\
\text { cooperative action possible." } \\
\text { The socio-ecological concept of } \\
\text { social capital provides a way of } \\
\text { talking about and identifying }\end{array}$ & $\begin{array}{l}\text { assessing and strengthening } 5 \\
\text { dimensions of social capital } \\
\text { within their organizations: (1) } \\
\text { groups and net- works, (2) trust } \\
\text { and solidarity, (3) collective } \\
\text { action and cooperation, (4) } \\
\text { information and communication, } \\
\text { and (5) social cohesion and } \\
\text { inclusion. }\end{array}$ & $\begin{array}{l}\text { Bonding, Bridging, } \\
\text { Linking } \\
\text { Trust } \\
\text { Cooperation } \\
\text { Social Norms } \\
\text { Cohesion } \\
\text { Inclusion }\end{array}$ \\
\hline
\end{tabular}




\begin{tabular}{|c|c|c|c|c|}
\hline & & $\begin{array}{l}\text { the nature and impact of critical } \\
\text { relationships between people } \\
\text { from diverse backgrounds who } \\
\text { need to cooperate and ex- } \\
\text { change information in complex } \\
\text { systems.20 Fundamentally, } \\
\text { social capital consists of } \\
\text { structural features (bonding, } \\
\text { bridging and linking) and } \\
\text { relational cognitive norms that } \\
\text { enable people to work } \\
\text { collectively to solve problems } \\
\text { and achieve common goals. }\end{array}$ & & $\begin{array}{l}\text { Solidarity } \\
\text { Reciprocity } \\
\text { Social network } \\
\text { Collective Action }\end{array}$ \\
\hline $\begin{array}{l}16 . \\
\text { Muntaner, C., Lynch, } \\
\text { J., \& Smith, G.D. } \\
\text { (2000). Social capital } \\
\text { and the third way in } \\
\text { public health. Critical } \\
\text { Public Health,Vol. 10, } \\
\text { No. } 2 . \\
\text { USA }\end{array}$ & $\begin{array}{l}\text { critically evaluate the } \\
\text { concept of social } \\
\text { capital to explore the } \\
\text { sources of the } \\
\text { connections among } \\
\text { different individuals } \\
\text { and groups, to } \\
\text { understand what is } \\
\text { transmitted over those } \\
\text { networks that might be } \\
\text { plausibly linked to } \\
\text { health outcomes, and } \\
\text { to understand how the } \\
\text { health relevant aspects } \\
\text { of the connections } \\
\text { among individuals and } \\
\text { groups can be changed } \\
\text { to improve public } \\
\text { health. }\end{array}$ & $\begin{array}{l}\text { The literature on different } \\
\text { approaches to social capital } \\
\text { (e.g., communitarian, network, } \\
\text { institutional) has been growing } \\
\text { for the last three decades, from } \\
\text { Loury, Bourdieu and Coleman, } \\
\text { to Portes, Evans and Putnam } \\
\text { (Coleman, 1990; Putnam, } \\
\text { 1995b). However, not until the } \\
\text { 1990s has the concept of social } \\
\text { capital/social cohesion gained } \\
\text { popularity in public health } \\
\text { (e.g.,Wilkinson, 1996) and } \\
\text { development studies } \\
\text { (Woolcock, 1998). } \\
\text { Seminal work of Evans (1995) } \\
\text { on economic development, this } \\
\text { institutional approach considers }\end{array}$ & $\begin{array}{l}\text { Will tossing all these dimensions } \\
\text { into the grab bag of social capital } \\
\text { can inform strategies to improve } \\
\text { public health? } \\
\text { the institutional approach to } \\
\text { social capital favoured by } \\
\text { Woolcock (1998) seems to be } \\
\text { open to this kind of integration } \\
\text { (e.g., Evans, 1995). But then, as } \\
\text { public health scholars and } \\
\text { activists, should we place false } \\
\text { hopes on initiatives heralded by } \\
\text { institutions (Amin, 1997) that } \\
\text { have helped generate the health } \\
\text { inequalities that we want to } \\
\text { eliminate? }\end{array}$ & $\begin{array}{l}\text { Strength of ties- } \\
\text { bonding, bridging, } \\
\text { linking }\end{array}$ \\
\hline
\end{tabular}




\begin{tabular}{|c|c|c|c|c|}
\hline & & $\begin{array}{l}\text { both a communities' social } \\
\text { capital - its internal cohesion, } \\
\text { ties and networks - as well as } \\
\text { the type of relation that the state } \\
\text { has with communities (Szreter, } \\
\text { 1999). } \\
\text { Putnam } \\
\text { Grootaert, Woolcock }\end{array}$ & & \\
\hline $\begin{array}{l}17 . \\
\text { Hanks, C. (2008). } \\
\text { Social Capital in an } \\
\text { Impoverished } \\
\text { Minority } \\
\text { Neighborhood: } \\
\text { Emergence and } \\
\text { Effects on Children's } \\
\text { Mental Health. } \\
\text { Journal of Child and } \\
\text { Adolescent } \\
\text { Psychiatric Nursing. } \\
\text { Volume 21, Issue 3. } \\
\text { Pages 126-136 } \\
\text { USA }\end{array}$ & $\begin{array}{l}\text { Social Capital Theory, } \\
\text { the a priori hypotheses } \\
\text { for this case study of a } \\
\text { low-income, minority } \\
\text { urban neighborhood } \\
\text { are that parents will } \\
\text { form cohesive } \\
\text { networks, agree on } \\
\text { children's behavioral } \\
\text { norms, and act } \\
\text { collaboratively to } \\
\text { enforce those norms } \\
\text { for all neighborhood } \\
\text { children. }\end{array}$ & $\begin{array}{l}\text { James Coleman (1988) called } \\
\text { his theory of informal social } \\
\text { control Social Capital. He } \\
\text { defined Social Capital as a } \\
\text { dynamic process of interactions } \\
\text { among closed } \\
\text { networks of parents and their } \\
\text { children in schools or } \\
\text { neighborhoods, which fostered } \\
\text { agreement on children's } \\
\text { behavioral norms as well as } \\
\text { enforcement of those norms. }\end{array}$ & $\begin{array}{l}\text { Coleman tested Social Capital } \\
\text { Theory by comparing children's } \\
\text { academic performances in public- } \\
\text { and church-run schools. Church- } \\
\text { run schools had more Social } \\
\text { Capital and, consequently, } \\
\text { children had better educational } \\
\text { outcomes, controlling for } \\
\text { pertinent individual and family } \\
\text { characteristics. } \\
\text { Application of the SC framework } \\
\text { = development of improved } \\
\text { neighborhood conditions for } \\
\text { children in a low resourced } \\
\text { community. }\end{array}$ & $\begin{array}{l}\text { Social Networks } \\
\text { Norms } \\
\text { Bonding, bridging, } \\
\text { linking }\end{array}$ \\
\hline $\begin{array}{l}18 . \\
\text { Samuel, L.J., } \\
\text { Commodore- } \\
\text { Mensah,Y. \& Dennison }\end{array}$ & $\begin{array}{l}\text { to (a) systematically } \\
\text { survey the empirical } \\
\text { use of community } \\
\text { social capital concepts }\end{array}$ & $\begin{array}{l}\text { resources in social networks } \\
\text { that are useful for an individual } \\
\text { to enact behaviors. }\end{array}$ & $\begin{array}{l}\text { The conceptual model proposes } \\
\text { that components of community } \\
\text { social capital, such as } \\
\text { trustworthiness, neighborly }\end{array}$ & $\begin{array}{l}\text { Access to information } \\
\text { Social Norms }\end{array}$ \\
\hline
\end{tabular}




\begin{tabular}{|c|c|c|c|c|}
\hline $\begin{array}{l}\text { Himmelfarb, C.R. } \\
\text { (2014). Developing } \\
\text { Behavioral Theory } \\
\text { With the Systematic } \\
\text { Integration of } \\
\text { Community Social } \\
\text { Capital Concepts. } \\
\text { Health Education \& } \\
\text { Behavior 2014, Vol. } \\
\text { 41(4) 359-375 } \\
\text { USA }\end{array}$ & $\begin{array}{l}\text { to identify and define } \\
\text { concepts related to } \\
\text { health behaviors and } \\
\text { (b) propose a testable } \\
\text { conceptual framework } \\
\text { that integrates the } \\
\text { concepts into existing } \\
\text { behavioral theory } \\
\text { based on both } \\
\text { empirical and } \\
\text { theoretical literature. }\end{array}$ & $\begin{array}{l}\text { Putnam and Bourdieu } \\
\text { Social capital varies by setting } \\
\text { but may include access to } \\
\text { information or behavioral } \\
\text { norms, freedom to trust other } \\
\text { group members, or ability to } \\
\text { expect supportive help from } \\
\text { others (Coleman, 1988) }\end{array}$ & $\begin{array}{l}\text { reciprocity, and sense of } \\
\text { community, operate via two main } \\
\text { pathways to affect behavior. } \\
\text { Results suggest that a major } \\
\text { limitation of existing literature is } \\
\text { the lack of theoretical grounding. } \\
\text { Despite recent calls from the } \\
\text { Institute of Medicine for } \\
\text { multilevel interventions (Institute } \\
\text { of Medicine, 2000), relatively few } \\
\text { interventions thus far have } \\
\text { targeted social and contextual } \\
\text { environmental factors at city, } \\
\text { neighborhood, or group levels } \\
\text { (Golden \& Earp, 2012). }\end{array}$ & $\begin{array}{l}\text { Trust } \\
\text { Support } \\
\text { Social Network }\end{array}$ \\
\hline $\begin{array}{l}19 . \\
\text { Lewis, J.M., } \\
\text { DiGiacomo, M., } \\
\text { Luckett, T., Patricia M. } \\
\text { Davidson, P.M., \& } \\
\text { Currow, D.C. (2013). A } \\
\text { Social Capital } \\
\text { Framework for } \\
\text { Palliative Care: } \\
\text { Supporting Health and } \\
\text { Well-Being for People } \\
\text { With Life-Limiting } \\
\text { Illness and Their Carers } \\
\text { Through Social } \\
\text { Relations and } \\
\text { Networks. Journal of }\end{array}$ & $\begin{array}{l}\text { summarize the } \\
\text { literature on social } \\
\text { capital, well-being, } \\
\text { and quality of life for } \\
\text { key outcomes to } \\
\text { inform a model of } \\
\text { social capital in } \\
\text { palliative care. }\end{array}$ & $\begin{array}{l}\text { Lin described social capital in } \\
\text { terms of network theory: } \\
\text { "resources embedded in social } \\
\text { networks accessed and used by } \\
\text { actors for actions," also } \\
\text { conceptualizing and measuring } \\
\text { social capital as individual and } \\
\text { collective assets. } \\
\text { Harpham described structural } \\
\text { social capital as what people } \\
\text { "do" and cognitive social } \\
\text { capital as what people "feel." } \\
\text { Social capital is a distinct } \\
\text { concept within public health, }\end{array}$ & $\begin{array}{l}\text { A social capital framework has } \\
\text { the capacity to support health and } \\
\text { well-being through connections, } \\
\text { information exchange, and } \\
\text { resource acquisition and leverage } \\
\text { The integration of "social } \\
\text { prescribing" into some general } \\
\text { practice/primary care models was } \\
\text { a social capital innovation that } \\
\text { aimed at empowering } \\
\text { communities to address health } \\
\text { and well-being needs that were } \\
\text { unresponsive to biomedical } \\
\text { therapies. A "social } \\
\text { prescription" from a primary care }\end{array}$ & $\begin{array}{l}\text { Bonding, bridging, } \\
\text { linking } \\
\text { Social networks } \\
\text { Connection } \\
\text { Information }\end{array}$ \\
\hline
\end{tabular}




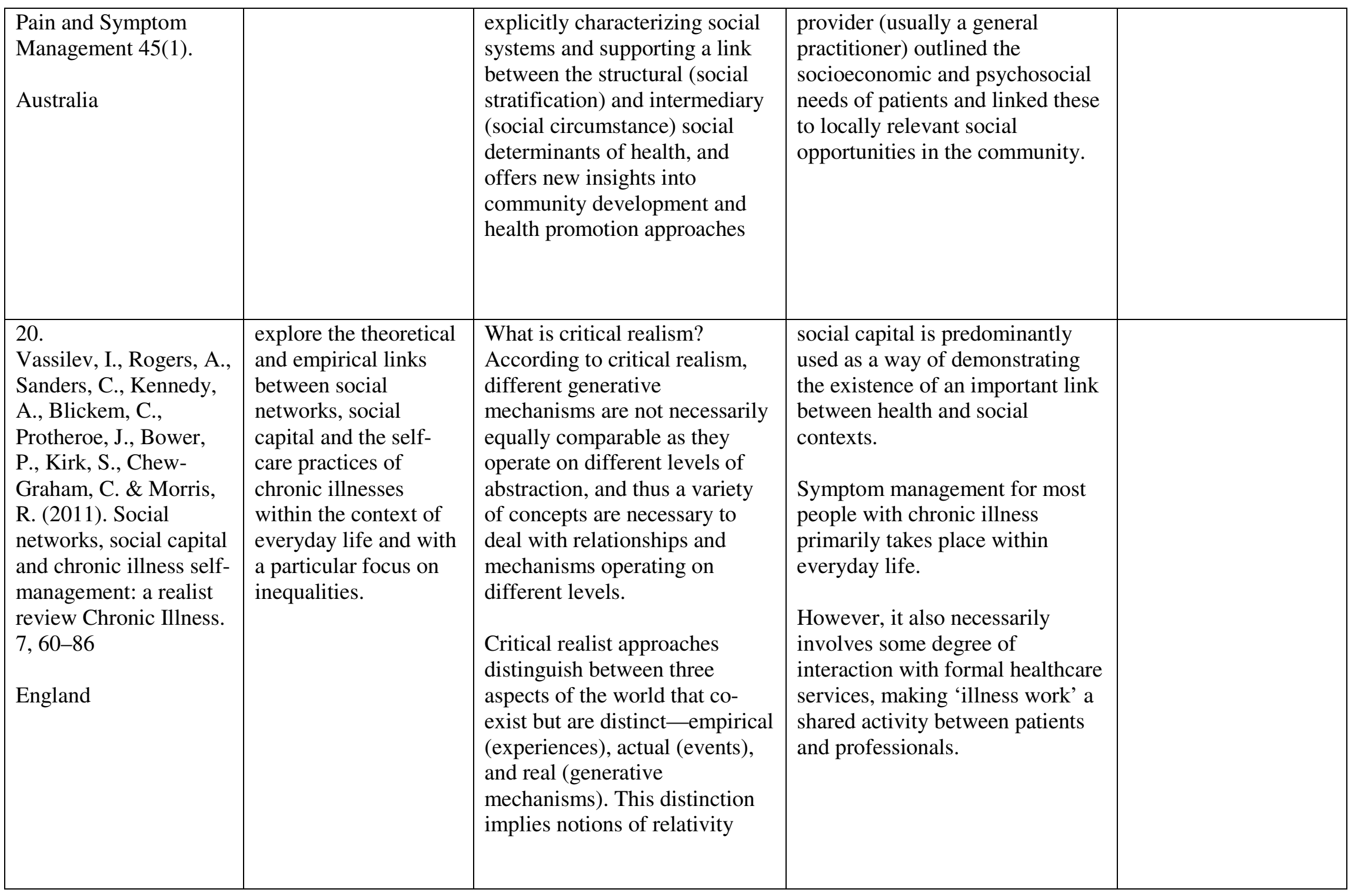




\begin{tabular}{|c|c|c|c|c|}
\hline $\begin{array}{l}21 . \\
\text { Read, E.A. \& } \\
\text { Laschinger, H.K.S. } \\
\text { (2015). The influence } \\
\text { of authentic leadership } \\
\text { and empowerment on } \\
\text { nurses' relational social } \\
\text { capital, mental health } \\
\text { and job satisfaction } \\
\text { over the first year of } \\
\text { practice. Journal of } \\
\text { Advanced Nursing. } \\
\text { Volume 71, Issue } 7, \\
\text { Pages 1611-1623 } \\
\text { DOI: 10.1111/jan.1262 } \\
5 \\
\text { Canada }\end{array}$ & $\begin{array}{l}\text { to test a hypothe- } \\
\text { sized model linking } \\
\text { authentic leadership } \\
\text { and structural } \\
\text { empowerment to } \\
\text { relational social } \\
\text { capital and } \\
\text { subsequently to new } \\
\text { graduate nurses' } \\
\text { mental health and job } \\
\text { satisfaction over the } \\
\text { first year of practice. }\end{array}$ & $\begin{array}{l}\text { Nahapiet and Ghoshal's (1998) } \\
\text { theory of social capital } \\
\text { describes three forms of social } \\
\text { capital that are created through } \\
\text { and embedded in interpersonal } \\
\text { relationships. }\end{array}$ & $\begin{array}{l}\text { Social capital theory (Nahapiet \& } \\
\text { Ghoshal 1998) is emerging as a } \\
\text { useful framework to explain how } \\
\text { social resources create positive } \\
\text { experiences at work and lead to } \\
\text { beneficial outcomes for nurses } \\
\text { and healthcare organizations. } \\
\text { Social capital has been associated } \\
\text { with lower levels of burnout } \\
\text { (Kowalski et al. 2010), better risk } \\
\text { management behaviour } \\
\text { (Ernstmann et al. 2009) and } \\
\text { organizational commitment and } \\
\text { pro-social customer service } \\
\text { behaviours (Hsu et al. 2011) } \\
\text { among hospital nurses. In a recent } \\
\text { multi-level analysis } \\
\text { Relational social capital is an } \\
\text { important interpersonal } \\
\text { resource embedded in } \\
\text { relationships that employees have } \\
\text { with one another (Nahapiet \& } \\
\text { Ghoshal 1998). }\end{array}$ & $\begin{array}{l}\text { Trust } \\
\text { Reciprocity } \\
\text { Social Network }\end{array}$ \\
\hline $\begin{array}{l}22 . \\
\text { Read,E.A. (2014). } \\
\text { Workplace social } \\
\text { capital in nursing: an } \\
\text { evolutionary concept } \\
\text { analysis. Journal of } \\
\text { Advanced }\end{array}$ & $\begin{array}{l}\text { Concept analysis } \\
\text { identify the attributes } \\
\text { of nurses' workplace } \\
\text { social capital by } \\
\text { conducting a concept } \\
\text { analysis using the }\end{array}$ & $\begin{array}{l}\text { Work-place social capital refers } \\
\text { to the idea that networks of } \\
\text { social relationships create value } \\
\text { and resources for individuals } \\
\text { and organizations (DiCicco- } \\
\text { Bloom et al. } 2008\end{array}$ & $\begin{array}{l}\text { The attributes of nurses' } \\
\text { workplace social capital identified } \\
\text { in this study are: a) networks of } \\
\text { social relationships at work; b) } \\
\text { shared assets; and c) shared ways } \\
\text { of knowing and being. }\end{array}$ & $\begin{array}{l}\text { Networks of } \\
\text { relationships at work } \\
\text { Shared assets } \\
\text { Shared ways of } \\
\text { knowing and being }\end{array}$ \\
\hline
\end{tabular}




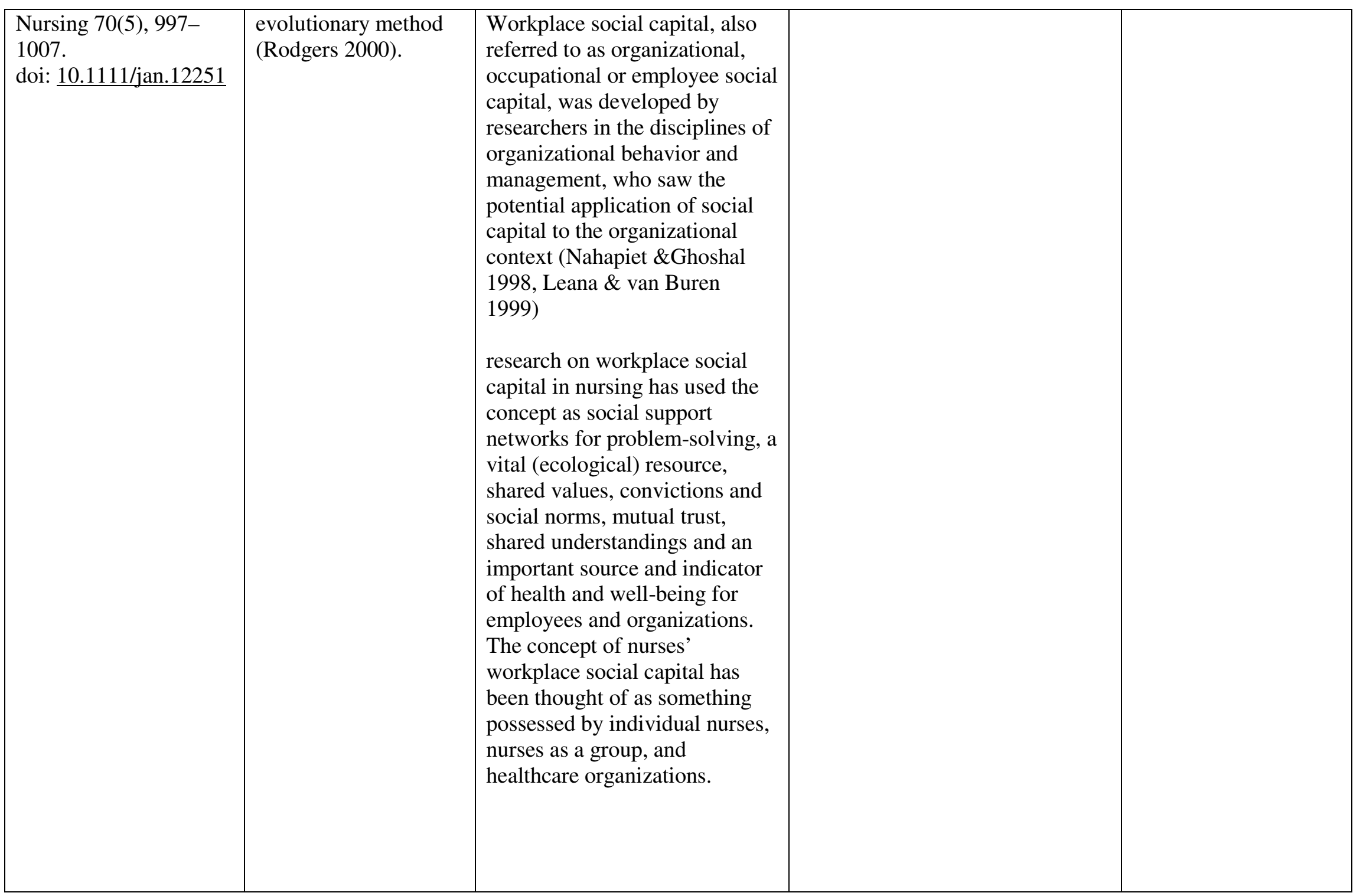




\begin{tabular}{|c|c|c|c|c|}
\hline $\begin{array}{l}23 . \\
\text { Hsieh, Ching-Hsing. } \\
\text { (2008) A concept } \\
\text { analysis of social } \\
\text { capital within a health } \\
\text { context. Nursing } \\
\text { forum. v. } 43 \text {. no. 3. p. } \\
151-9\end{array}$ & Concept analysis & $\begin{array}{l}\mathrm{SC}=\text { ecological characteristic } \\
\text { of sociality }\end{array}$ & $\begin{array}{l}\text { "A pearl necklace is made by } \\
\text { using a silk thread to connect } \\
\text { individual pearls. Under the } \\
\text { concept of social capital, nursing } \\
\text { has a role to play similar to the } \\
\text { silk thread that connects the } \\
\text { pearls. Nursing can integrate } \\
\text { individuals and families into a } \\
\text { cohesive community through } \\
\text { home visits, and encourage } \\
\text { individuals and families to get } \\
\text { involved in community activities, } \\
\text { as well as to foster a sense of } \\
\text { belonging in the community. As } \\
\text { the participation in community } \\
\text { activities and the sense of } \\
\text { belonging increase, social capital } \\
\text { increases at the same time. Good } \\
\text { results can be effectively } \\
\text { achieved when a nurse takes steps } \\
\text { in nursing intervention, such as } \\
\text { providing group health education } \\
\text { and designing an exercise } \\
\text { program to improve the health of } \\
\text { the residents and families in a } \\
\text { community with high level of } \\
\text { social capital." }\end{array}$ & $\begin{array}{l}\text { Trust } \\
\text { Networks } \\
\text { Norms of Reciprocity }\end{array}$ \\
\hline
\end{tabular}




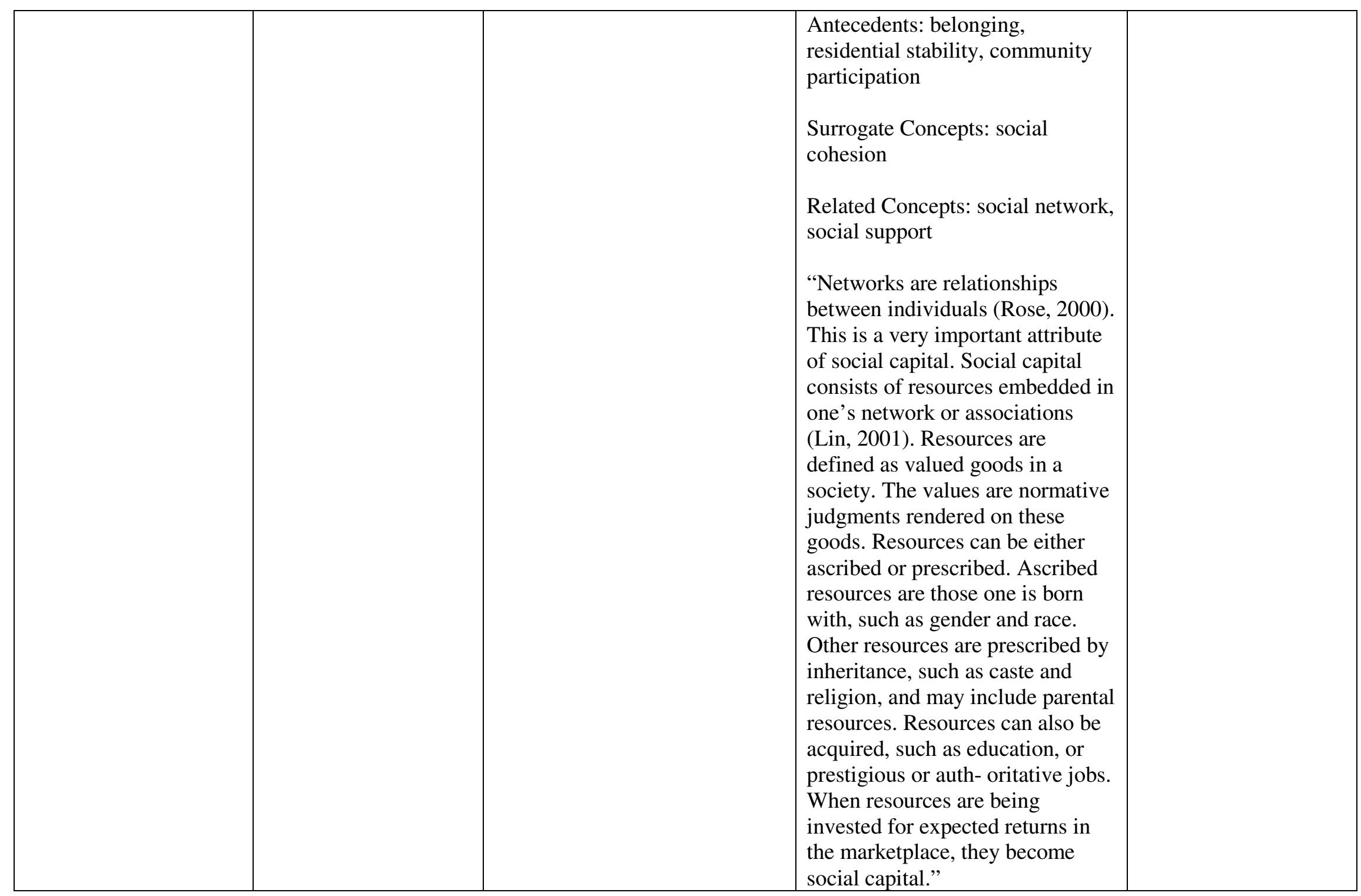




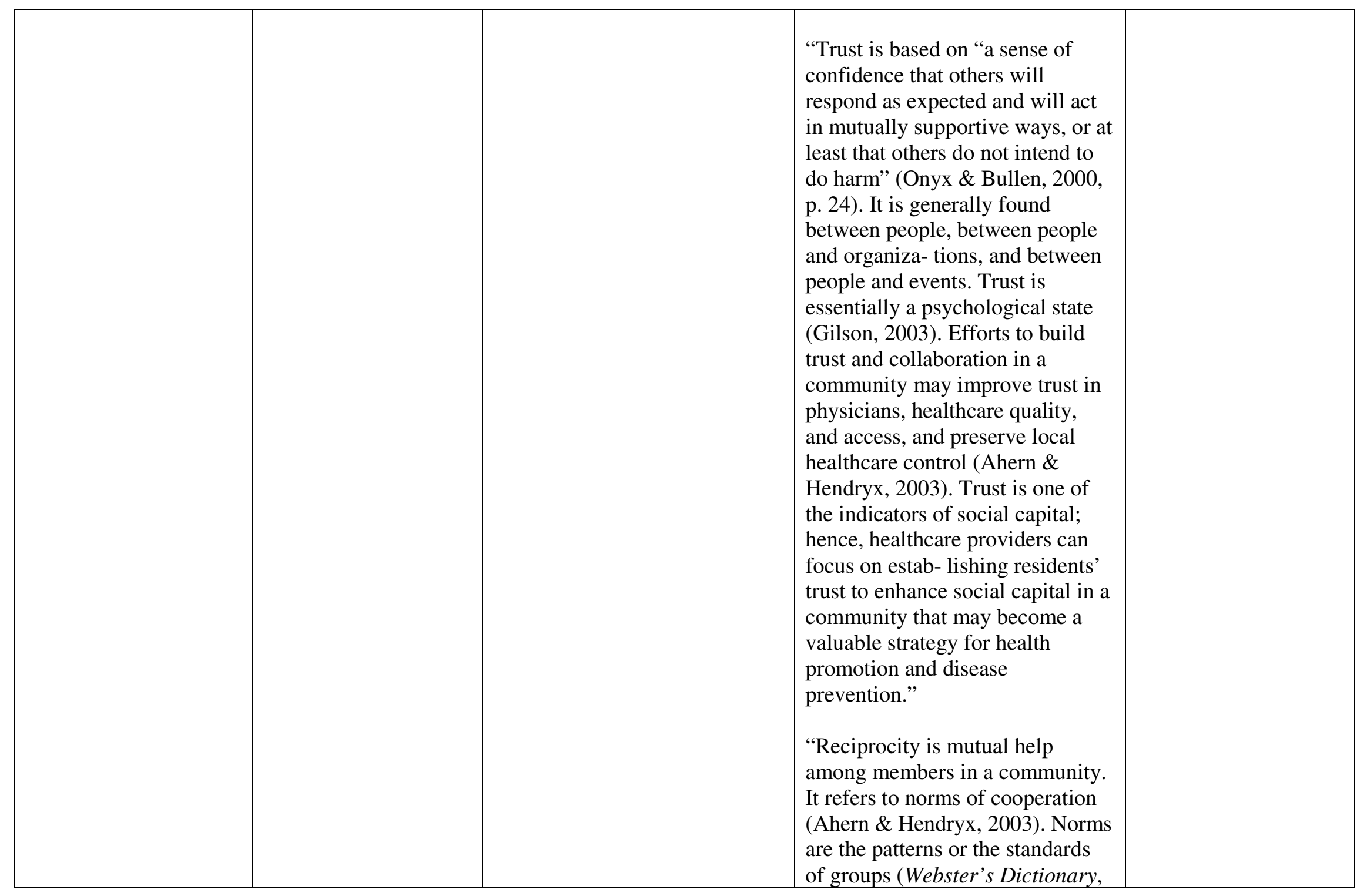




\begin{tabular}{|l|l|l|l|}
\hline & & & $\begin{array}{l}\text { 1995). A norm of reciprocity } \\
\text { makes two interrelated demands: } \\
\text { first, people should help those } \\
\text { who have helped them; and, } \\
\text { second, people should not injure } \\
\text { those who have helped them } \\
\text { (Gouldner, 1960)." }\end{array}$ \\
\hline
\end{tabular}


Table 3.

Qualitative papers involving social capital and nursing $(n=7)$ bolded article titles indicate pediatric content

\begin{tabular}{|c|c|c|c|}
\hline $\begin{array}{c}\text { AUTHOR } \\
\text { COUNTRY }\end{array}$ & $\begin{array}{c}\text { PURPOSE } \\
\text { TYPE OF STUDY }\end{array}$ & RESULTS & ATTRIBUTES \\
\hline $\begin{array}{l}\text { 1. } \\
\text { Looman WS. (2004). Defining } \\
\text { Social Capital for Nursing: } \\
\text { Experiences of Family } \\
\text { Caregivers of Children with } \\
\text { Chronic Conditions. Journal of } \\
\text { Family Nursing. 10(4): 412- } \\
\text { 428. } \\
\text { USA }\end{array}$ & $\begin{array}{l}\text { "describe the multi- } \\
\text { dimensional nature of social } \\
\text { capital as experienced by } \\
\text { parental care- givers of } \\
\text { children with special health } \\
\text { care needs (CSHCN)." } \\
\text { Phenomenology } \\
\text { Putnam, Coleman, Bourdieu }\end{array}$ & $\begin{array}{l}\text { Context matters- neighbors, faith- } \\
\text { based organizations, schools, and } \\
\text { communities. } \\
\text { The parental caregivers in this study } \\
\text { have clearly defined health as } \\
\text { contextual. } \\
\text { "Recognizing parents as team players } \\
\text { or partner in a network that exists to } \\
\text { help families" } \\
\text { Health care delivery system is the } \\
\text { community with the family as the } \\
\text { hub. } \\
\text { "an investment in relationships, is a } \\
\text { phenomenon that coincides with a } \\
\text { move toward theoretical } \\
\text { conceptualizations of the connections } \\
\text { between social relations and } \\
\text { population health." }\end{array}$ & $\begin{array}{l}5 \text { dimensions derived from } \\
\text { thematic analysis: } \\
\text { advocacy } \\
\text { common good } \\
\text { community } \\
\text { trust } \\
\text { the system- seeing health care } \\
\text { as more of a process than } \\
\text { something that the family is a } \\
\text { part of }\end{array}$ \\
\hline
\end{tabular}




\begin{tabular}{|c|c|c|c|}
\hline $\begin{array}{l}2 . \\
\text { Manton, E.,Amy Pennay, A. \& } \\
\text { Savic, M.(2014). Public } \\
\text { drinking, social connection and } \\
\text { social capital: A qualitative } \\
\text { study. Addiction Research and } \\
\text { Theory. 22(3): 218-228. } \\
\text { Australia }\end{array}$ & $\begin{array}{l}\text { "draw on the observational } \\
\text { data and semi-structured } \\
\text { qualitative interviews with } \\
\text { street drinkers from three } \\
\text { districts." } \\
\text { Thematic analysis was } \\
\text { performed by all authors and } \\
\text { themes, then cross-checked } \\
\text { and validated among the } \\
\text { team. } \\
\text { Putnam }\end{array}$ & $\begin{array}{l}\text { implies that fostering existing social } \\
\text { connections would be a desirable } \\
\text { form of public health action. }\end{array}$ & $\begin{array}{l}\text { Social connection } \\
\text { Bonding, bridging, linking } \\
\text { Trust } \\
\text { Reciprocity }\end{array}$ \\
\hline $\begin{array}{l}\text { 3. } \\
\text { Sharma'S. \&Reimer-Kirkham, } \\
\text { S. (2015) Faith as social capital: } \\
\text { Diasporic women negotiating } \\
\text { religion in secularized healthcare } \\
\text { services. Women's Studies } \\
\text { International Forum.v } 49 \text { Pages } \\
\text { 34-42. } \\
\underline{\text { https://doi.org/10.1016/j.wsif.20 }} \\
\underline{15.01 .005} \\
\text { England }\end{array}$ & $\begin{array}{l}\text { "contribute to the growing } \\
\text { body of literature that } \\
\text { examines the lived religion } \\
\text { of diasporic communities } \\
\text { and in particular women } \\
\text { members who employ their } \\
\text { faith to navigate healthcare } \\
\text { work." } \\
\text { First-hand accounts from } \\
\text { diasporic women in } \\
\text { healthcare } \\
\text { Putnam }\end{array}$ & $\begin{array}{l}\text { As demonstrated by the Sikh } \\
\text { community, their ability to bridge } \\
\text { came not only from confidence in } \\
\text { their faith tradition and long-historical } \\
\text { presence within the community, but } \\
\text { in how they utilized these aspects to } \\
\text { mobilize and organize themselves. } \\
\text { They moved beyond bonding forms } \\
\text { of social capital that were limiting } \\
\text { their experiences of their religious } \\
\text { rituals within their local hospital, to } \\
\text { bridging which the whole community } \\
\text { could benefit from. }\end{array}$ & $\begin{array}{l}\text { Social networks } \\
\text { Reciprocity } \\
\text { Trustworthiness } \\
\text { Bonding, bridging, linking }\end{array}$ \\
\hline $\begin{array}{l}4 . \\
\text { Manoochehri, H., Lolaty, H.A., } \\
\text { Hassani, P., Arbon, P., \& } \\
\text { Shorofi, S.A.(2014) Iranian }\end{array}$ & $\begin{array}{l}\text { "explore the role of social } \\
\text { capital within the context of } \\
\text { the nursing profession in } \\
\text { Iran, based on the experience }\end{array}$ & $\begin{array}{l}\text { The concept of social capital appears } \\
\text { to be valuable for the development of } \\
\text { healthcare organizations. }\end{array}$ & $\begin{array}{l}\text { Content analysis revealed } \\
\text { three main themes: } \\
\text { (1) social capital deficit }\end{array}$ \\
\hline
\end{tabular}




\begin{tabular}{|c|c|c|c|}
\hline $\begin{array}{l}\text { senior nursing managers' } \\
\text { experiences and understanding } \\
\text { of social capital in the nursing } \\
\text { profession. Sep-Oct; 19(5): 464- } \\
472 . \\
\text { England }\end{array}$ & $\begin{array}{l}\text { and perspectives of senior } \\
\text { nursing managers." } \\
\text { Graneheim and Lundman } \\
\text { content analysis method. }\end{array}$ & $\begin{array}{l}\text { The study results indicate that social } \\
\text { capital can be improved in nursing by } \\
\text { encouraging collective efforts, } \\
\text { applying multiple strategies, } \\
\text { expanding communication networks, } \\
\text { creating a supportive work } \\
\text { environment, improving } \\
\text { accountability in the healthcare } \\
\text { system, creating clear organizational } \\
\text { boundaries, and modifying power } \\
\text { structures. }\end{array}$ & $\begin{array}{l}\text { (2) the application of multiple } \\
\text { strategies } \\
\text { (3) cultivating social capital } \\
\text { Trust } \\
\text { Reciprocity } \\
\text { Mutual benefit } \\
\text { Collective Action }\end{array}$ \\
\hline $\begin{array}{l}5 . \\
\text { Bhattacharya, G. (2011). Global } \\
\text { Contexts, Social Capital, and } \\
\text { Acculturative Stress: } \\
\text { Experiences of Indian Immigrant } \\
\text { Men in New York City. J } \\
\text { Immigrant Minority Health } \\
\text { 13:756-765 } \\
\text { DOI 10.1007/s10903-011-9444- } \\
\text { y } \\
\text { USA }\end{array}$ & $\begin{array}{l}\text { "Grounded in social capital } \\
\text { approach and immigrant } \\
\text { health framework, this } \\
\text { qualitative, community- } \\
\text { based study examined the } \\
\text { social networks of } \\
\text { immigrant men from India to } \\
\text { New York City." } \\
\text { Grounded Theory }\end{array}$ & $\begin{array}{l}\text { Participants identified social capital } \\
\text { elements and linked those with their } \\
\text { social capital resources in family, } \\
\text { peers, and community in NYC } \\
\text { Interventions must take into account } \\
\text { the social capital variations that exist } \\
\text { among subgroups of the same ethnic } \\
\text { community. }\end{array}$ & $\begin{array}{l}\text { Belonging } \\
\text { Trust } \\
\text { Mutual Concern } \\
\text { Family Bonding } \\
\text { Reciprocity } \\
\text { Peer social support } \\
\text { Connectedness } \\
\text { Coping } \\
\text { Solidarity } \\
\text { Ethnic pride } \\
\text { Culture identity }\end{array}$ \\
\hline
\end{tabular}




\begin{tabular}{|c|c|c|c|}
\hline & & & $\begin{array}{l}\text { Civic Ties } \\
\text { Community Cohesion }\end{array}$ \\
\hline $\begin{array}{l}6 . \\
\text { Lewis, J.M., DiGiacomo, M., } \\
\text { Currow, D.C., Davidson, } \\
\text { P.M.(2014). Social capital in a } \\
\text { lower socioeconomic palliative } \\
\text { care population: a qualitative } \\
\text { investigation of individual, } \\
\text { community and civic networks } \\
\text { and relations.BioMed Central } \\
\text { Palliative Care 13:30. }\end{array}$ & $\begin{array}{l}\text { "Explore the nature of social } \\
\text { capital in a } \\
\text { socioeconomically } \\
\text { disadvantaged group of } \\
\text { palliative care patients and } \\
\text { caregivers, using a social } \\
\text { capital questionnaire to } \\
\text { guide and frame } \\
\text { discussions." }\end{array}$ & $\begin{array}{l}\text { an investigator- developed social } \\
\text { capital questionnaire (SCQ). The six- } \\
\text { teen items comprising the } \\
\text { questionnaire were derived from the } \\
\text { World Bank's Social Capital } \\
\text { Assessment Tool (SOCAT) [25] } \\
\text { The SCQ developed for the study } \\
\text { asked specific questions about } \\
\text { networks and relations at individual, } \\
\text { community and civic levels. They } \\
\text { were also asked about the quality and } \\
\text { extent of trust and cohesion within } \\
\text { and between these networks and } \\
\text { relations } \\
\text { Existing research reports that } \\
\text { informal family networks and } \\
\text { relations in disadvantaged populations } \\
\text { can be inad- equate in their capacity } \\
\text { to support caregiving, due to the } \\
\text { nature of family conflict [7] and } \\
\text { additionally due to the limits of } \\
\text { resources available to this group } \\
\text { [33,34]. The model of informal family } \\
\text { caregiving, revered in palliative care } \\
\text { theory, therefore requires a rethink } \\
\text { most urgently, particularly in }\end{array}$ & $\begin{array}{l}\text { Structural (network)- what } \\
\text { people do } \\
\text { Cognitive(social cohesion)- } \\
\text { what people perceive } \\
\text { Bonding, bridging, linking } \\
\text { Network } \\
\text { Values } \\
\text { Norms } \\
\text { Quality of relationships }\end{array}$ \\
\hline
\end{tabular}




\begin{tabular}{|c|c|c|c|}
\hline & & $\begin{array}{l}\text { socioeconomically disadvantaged } \\
\text { populations [7]. }\end{array}$ & \\
\hline $\begin{array}{l}7 . \\
\text { Farnum, K., McCarthy, M., } \\
\text { Beauchesne, M.A., \& Lawrence, } \\
\text { P.R. (2005). The Primary Care } \\
\text { for the underserved conference } \\
\text { as a building block to social } \\
\text { capital: impact on practice, } \\
\text { research, and education Journal } \\
\text { of Cultural Diversity. } \\
\text { Winter2005, Vol. } 12 \text { Issue 4, } \\
\text { p126-135. }\end{array}$ & $\begin{array}{l}\text { The purpose of this critical } \\
\text { analysis is to evaluate the } \\
\text { impact of the Primary Care } \\
\text { for the Underserved } \\
\text { Conference on practice, } \\
\text { research, and education } \\
\text { within the conceptual } \\
\text { framework of social capital. }\end{array}$ & $\begin{array}{l}\text { The main purpose of the Primary } \\
\text { Care for the Underserved Conference } \\
\text { is to explore emerging trends and } \\
\text { patterns in health care practices and } \\
\text { research related to serving the } \\
\text { underserved in the U.S. and abroad. } \\
\text { The authors use the construct of } \\
\text { "social capital" to conceptualize the } \\
\text { interconnectedness of social relations } \\
\text { and health care. } \\
\text { Looman and Lindeke (2005) } \\
\text { identified three steps in building } \\
\text { social capital: (1) setting the stage for } \\
\text { networking, (2) diffusing knowledge, } \\
\text { and (3) practicing "vision therapy." } \\
\text { This conceptual framework allows } \\
\text { healthcare providers to organize and } \\
\text { explore social capital and health care } \\
\text { in new and creative ways. }\end{array}$ & $\begin{array}{l}\text { social networks } \\
\text { norms of reciprocity } \\
\text { mutual assistance } \\
\text { trustworthiness }\end{array}$ \\
\hline
\end{tabular}


Table 4.

Review of Literature papers involving social capital and nursing $(n=5)$ bolded article titles indicate pediatric content

\begin{tabular}{|c|c|c|c|c|}
\hline AUTHOR, COUNTRY & PURPOSE & $\begin{array}{c}\text { DEFINITION OF } \\
\text { SOCIAL CAPITAL } \\
\text { SOCIAL CAPITAL } \\
\text { THEORY }\end{array}$ & DISCUSSION & ATTRIBUTES \\
\hline $\begin{array}{l}\text { 1. } \\
\text { Royal, J. (2012). Evaluating } \\
\text { human, social and cultural } \\
\text { capital in nurse education. } \\
\text { Nurse Education Toda.y 32: } \\
\text { 19-22. } \\
\text { England }\end{array}$ & $\begin{array}{l}\text { "review of the } \\
\text { literature on human } \\
\text { social and cultural } \\
\text { capital from } 1986 \text { to } \\
\text { the present applied to } \\
\text { nurse education." } \\
\text { Integrative review }\end{array}$ & $\begin{array}{l}\text { "Social capital refers to } \\
\text { connections among } \\
\text { individuals-social } \\
\text { networks and the norms } \\
\text { of reciprocity and } \\
\text { trustworthiness that } \\
\text { arise from them." } \\
\text { Putnam } \\
\text { "Individuals maintain } \\
\text { and build social capital } \\
\text { through interactions } \\
\text { with other individuals } \\
\text { and with formal and } \\
\text { informal groups. In } \\
\text { belonging to groups } \\
\text { there can be benefits to } \\
\text { the individual and also } \\
\text { time or knowledge } \\
\text { given to other } \\
\text { individuals in the group }\end{array}$ & $\begin{array}{l}\text { Is nursing suffering from low } \\
\text { levels of social capital? } \\
\text { Exhibits: } \\
\text { 1. pushback for advanced } \\
\text { educational degrees in nursing } \\
\text { 2. growing public concern that } \\
\text { had emerged over the recent } \\
\text { years that nurses were } \\
\text { becoming 'too posh to wash' } \\
\text { (Fleming, 2009) and losing the } \\
\text { skills that equipped them to } \\
\text { care effectively and holistically } \\
\text { for patients. } \\
\text { 3. Difficulty recruiting } \\
\text { preceptors and mentoring. } \\
\text { 4.Participation in professional } \\
\text { nursing organizations }\end{array}$ & $\begin{array}{l}\text { Social Networks } \\
\text { Reciprocity } \\
\text { Trustworthiness } \\
\text { Belongingness } \\
\text { Shared Values } \\
\text { Participation }\end{array}$ \\
\hline
\end{tabular}




\begin{tabular}{|c|c|c|c|c|}
\hline & & $\begin{array}{l}\text { that can benefit them in } \\
\text { turn. " Coleman } \\
\text { Bourdieu }\end{array}$ & & \\
\hline $\begin{array}{l}2 . \\
\text { Gopee, N. (2002). Human } \\
\text { and social capital as } \\
\text { facilitators of lifelong } \\
\text { learning in nursing. Nurse } \\
\text { Education Today. 22(8) } \\
608-616 \\
\text { doi:10.1016/S0260- } \\
6917(02) 00139-9 \\
\text { England }\end{array}$ & $\begin{array}{l}\text { examine possible } \\
\text { ways in which } \\
\text { clinical managers can } \\
\text { maximize the use of } \\
\text { social and human } \\
\text { capital in the nursing } \\
\text { workforce. }\end{array}$ & $\begin{array}{l}\text { "social capital refers to } \\
\text { the time, patience, } \\
\text { teaching, etc, that } \\
\text { individuals 'invest' in } \\
\text { each other in relatively } \\
\text { closely knit social } \\
\text { groups and peers." } \\
\text { Putnam (1993) defines } \\
\text { social capital in terms } \\
\text { of four characteristics } \\
\text { that include the } \\
\text { existence of community } \\
\text { networks based on } \\
\text { norms of trust and } \\
\text { reciprocal help and } \\
\text { support. These } \\
\text { characteristics } \\
\text { constitute 'features of } \\
\text { social life networks that } \\
\text { enable participants to } \\
\text { act together more } \\
\text { effectively to pursue } \\
\text { shared objectives' } \\
\text { (Putnam } 1996 \text { p. } 66 \text { ) }\end{array}$ & $\begin{array}{l}\text { social capital has marked levels } \\
\text { of influence on stimulating } \\
\text { participation in both non-formal } \\
\text { and informal learning }\end{array}$ & $\begin{array}{l}\text { Social Networks } \\
\text { Trust } \\
\text { Reciprocity } \\
\text { Support } \\
\text { Participation } \\
\text { Shared Values }\end{array}$ \\
\hline
\end{tabular}




\begin{tabular}{|c|c|c|c|c|}
\hline $\begin{array}{l}\text { 3. } \\
\text { Sistrom, M.G. \& Hale, P.J. } \\
\text { (2006). Integrative Review } \\
\text { of population health, } \\
\text { income, social capital, and } \\
\text { structural inequality. } \\
\text { Journal of Multicultural } \\
\text { Nursing. 12(2) 21-27. } \\
\text { United States }\end{array}$ & $\begin{array}{l}\text { "integrative review } \\
\text { for the purpose of } \\
\text { exploring the } \\
\text { frameworks for } \\
\text { studying the } \\
\text { relationship of } \\
\text { inequality and } \\
\text { population health, } \\
\text { i.e., income, social } \\
\text { capital and neo- } \\
\text { material- ism; } \\
\text { analyze trends in } \\
\text { health disparities } \\
\text { research; and discuss } \\
\text { the place of nursing } \\
\text { in social justice." }\end{array}$ & $\begin{array}{l}\text { Social capital } \\
\text { encompasses the } \\
\text { elements of social } \\
\text { relationships that } \\
\text { facilitate mutually } \\
\text { beneficial collective } \\
\text { action. } \\
\text { Kawachi }\end{array}$ & $\begin{array}{l}\text { A governing philosophy of } \\
\text { individualism and personal } \\
\text { freedom leaves Americans } \\
\text { unable to progress beyond self- } \\
\text { interest in advancing the health } \\
\text { of the population, even in light } \\
\text { of advancing societal } \\
\text { expectations for Health. } \\
\text { Kawachi suggests that policy } \\
\text { measures that strengthen social } \\
\text { capital within communities may } \\
\text { result in reductions in health } \\
\text { disparities (1999) } \\
\text { health disparities are not solely } \\
\text { a question of access to care or } \\
\text { health insurance. } \\
\text { "nursing's historic role in social } \\
\text { reform, the documents } \\
\text { implicitly reinforce nursing } \\
\text { practice directed towards } \\
\text { individual-nurse patient } \\
\text { relationships and give short } \\
\text { shrift to nursing models that } \\
\text { endorse broad systems change } \\
\text { intended to improve health" }\end{array}$ & $\begin{array}{l}\text { Trust } \\
\text { Reciprocity } \\
\text { Mutual Aid } \\
\text { Social Network } \\
\text { Participation }\end{array}$ \\
\hline $\begin{array}{l}4 . \\
\text { Nyqvista, F., Forsmanab, } \\
\text { A.K., Giuntolic, G., \& } \\
\text { Cattand, M.(2013).Social }\end{array}$ & $\begin{array}{l}\text { "explore the } \\
\text { relationship between } \\
\text { social capital and }\end{array}$ & $\begin{array}{l}\text { Putnam } \\
\text { Bourdieu } \\
\text { Coleman }\end{array}$ & $\begin{array}{l}\text { A possibility for future research } \\
\text { is therefore to follow } \\
\text { Bronfenbrenner's classical } \\
\text { division into macro, meso, and }\end{array}$ & $\begin{array}{l}\text { Trust } \\
\text { Norms }\end{array}$ \\
\hline
\end{tabular}




\begin{tabular}{|c|c|c|c|c|}
\hline $\begin{array}{l}\text { capital as a resource for } \\
\text { mental well-being in older } \\
\text { people: A systematic } \\
\text { review. Aging \& Mental } \\
\text { Health, 17, No. } 4,394-410 \\
\text { http://dx.doi.org/10.1080/1 } \\
\text { 3607863.2012.742490 } \\
\text { Finland }\end{array}$ & $\begin{array}{l}\text { mental well-being in } \\
\text { older people." } \\
\text { Systematic review }\end{array}$ & $\begin{array}{l}\text { AgeLine, ASSIA, ASE, } \\
\text { Cinahl, MedLine } \\
\text { (OVID), Psycinfo, } \\
\text { Socindex, Social } \\
\text { Services Abstracts, } \\
\text { Sociological Abstracts, } \\
\text { and Web of Science } \\
\text { between January } 1990 \\
\text { and September } 2011 . \\
\text { Altogether, } 583 \text { titles } \\
\text { and abstracts were } \\
\text { screened for relevance. } \\
\text { Of these, } 247 \text { full-text } \\
\text { articles were reviewed. } \\
\text { After application of the } \\
\text { study inclusion criteria, } \\
11 \text { articles were } \\
\text { identified to be eligible } \\
\text { for review. Each study } \\
\text { was assessed in terms } \\
\text { of seven possible } \\
\text { dimensions of social } \\
\text { capital exposure } \\
\text { measures }\end{array}$ & $\begin{array}{l}\text { micro levels. We consider } \\
\text { family and friends at the micro } \\
\text { level to be the key factors in } \\
\text { generating social capital and } \\
\text { well-being in older people. } \\
\text { The results showed that all } \\
\text { included studies found positive } \\
\text { associations between parts of } \\
\text { social capital and aspects of } \\
\text { mental well-being. }\end{array}$ & $\begin{array}{l}\text { Social Networkds } \\
\text { Connections- bonding, } \\
\text { bridging, linking }\end{array}$ \\
\hline $\begin{array}{l}5 . \\
\text { McPherson, KE, Kerr, S, } \\
\text { Morgan, A.,Cheater, FM, } \\
\text { \& Egan, J. (2014). The } \\
\text { association between social } \\
\text { capital and mental health } \\
\text { and behavioral problems } \\
\text { in children and } \\
\text { adolescents:an integrative }\end{array}$ & $\begin{array}{l}\text { 1. identify, analyze } \\
\text { and synthesize } \\
\text { primary evidence on } \\
\text { the association } \\
\text { between social capital } \\
\text { and mental health and } \\
\text { behavioral problems } \\
\text { in children and } \\
\text { adolescents. }\end{array}$ & $\begin{array}{l}\text { Bourdieu, Putnam, } \\
\text { Coleman }\end{array}$ & $\begin{array}{l}\text { social capital generated and } \\
\text { mobilized at the family and } \\
\text { community level can influence } \\
\text { mental health/problem behavior } \\
\text { outcomes in young people. In } \\
\text { addition, it highlights key gaps } \\
\text { in knowledge where future } \\
\text { research could further } \\
\text { illuminate the mechanisms }\end{array}$ & $\begin{array}{l}\text { Members of social } \\
\text { network } \\
\text { Shared Values } \\
\text { Communication } \\
\text { Social Norms/informal } \\
\text { control }\end{array}$ \\
\hline
\end{tabular}




\begin{tabular}{|c|c|c|c|}
\hline $\begin{array}{l}\text { review. BMC Psychol. } \\
\text { 2(1):7 } \\
\text { UK }\end{array}$ & $\begin{array}{l}\text { 2. discuss } \\
\text { implications for } \\
\text { future research and } \\
\text { policy development. } \\
\text { Integrative review }\end{array}$ & $\begin{array}{l}\text { through which social capital } \\
\text { works to influence health and } \\
\text { wellbeing and thus inform } \\
\text { policy development. } \\
\text { theorists such as Kawachi have } \\
\text { sought a more pluralistic } \\
\text { approach that attempts to unify } \\
\text { key elements that emerge from } \\
\text { the various traditions. This has } \\
\text { resulted in relative consensus } \\
\text { that social capital includes } \\
\text { those elements of social } \\
\text { networks that can bring about } \\
\text { positive social, economic and } \\
\text { health development across } \\
\text { multiple ecological systems. }\end{array}$ & $\begin{array}{l}\text { Parent interest in child } \\
\text { Support }\end{array}$ \\
\hline
\end{tabular}


Table 5.

Papers involving psychometric analysis, social capital and nursing $(n=4)$ bolded article titles indicate pediatric content

\begin{tabular}{|c|c|c|c|}
\hline $\begin{array}{c}\text { AUTHOR } \\
\text { COUNTRY }\end{array}$ & PURPOSE & $\begin{array}{c}\text { DEFINITION } \\
\text { METHODS } \\
\text { RESULTS }\end{array}$ & ATTRIBUTES \\
\hline $\begin{array}{l}1 . \\
\text { Koutra, K., Orfanos, P., } \\
\text { Roumeliotaki, T., } \\
\text { Kritsotakis, G., Kokkevi, } \\
\text { A., \& Philalithis, A. } \\
\text { (2012). Psychometric } \\
\text { Validation of the Youth } \\
\text { Social Capital Scale in } \\
\text { Greece Research on Social } \\
\text { Work Practice 22(3) 333- } \\
\text { 343 } \\
\text { DOI: } \\
\text { 10.1177/104973151142580 } \\
\text { Greece }\end{array}$ & $\begin{array}{l}\text { describe the } \\
\text { psychometric validation } \\
\text { of the YSCS, establish } \\
\text { the factor dimensions of } \\
\text { the Greek version of the } \\
\text { scale, compare findings } \\
\text { with those obtained } \\
\text { from the original } \\
\text { Australian study. }\end{array}$ & $\begin{array}{l}\text { "A multidimensional resource derived } \\
\text { from one's social networks, ties, and } \\
\text { relations with other people and groups } \\
\text { or communities." } \\
\text { Social capital of young people has } \\
\text { mainly been measured using } \\
\text { quantitative methods } \\
692 \text { first grade students } \\
\text { Based off of the Australian youth } \\
\text { Social Capital Scale (SCS) } \\
\text { Onyx et al., 2005 } \\
\text { Youth Social Capital scale } \\
\text { 1. factor analysis using the correlation } \\
\text { matrix } \\
\text { 2. The 9-step approach of the } \\
\text { Principles of Good Practice for the } \\
\text { Translation and Cultural Adaptation } \\
\text { was applied (Wild et al., 2005) to } \\
\text { translate into Greek } \\
\text { Cronbach alpha is } 0.771\end{array}$ & $\begin{array}{l}\text { Trust } \\
\text { Reciprocity } \\
\text { Mutuality }\end{array}$ \\
\hline
\end{tabular}




\begin{tabular}{|c|c|c|}
\hline & & $\begin{array}{l}\text { Main theorists of social capital have } \\
\text { been criticized for seeing children as } \\
\text { passive recipients of parental social } \\
\text { capital rather than active producers } \\
\text { who are capable of generating and } \\
\text { articulating their own construction of } \\
\text { self and society. To better understand } \\
\text { the social capital of youth, we must } \\
\text { first gain further insight into their } \\
\text { experiences and concerns regarding } \\
\text { life. }\end{array}$ \\
\hline $\begin{array}{l}2 . \\
\text { Looman, W. (2006). } \\
\text { Development and testing of } \\
\text { the social capital scale for } \\
\text { families of children with } \\
\text { special health care needs. } \\
\text { Research in Nursing and } \\
\text { Health.29(4):325-36 } \\
\text { DOI:10.1002/nur.20148 } \\
\text { USA }\end{array}$ & $\begin{array}{l}\text { Develop and } \\
\text { psychometrically test the } \\
\text { Social Capital Scale for } \\
\text { families of children with } \\
\text { special health care needs. } \\
\text { Several authors have } \\
\text { operationalized the } \\
\text { concept and identified } \\
\text { dimensions, resulting in a } \\
\text { number of scales or } \\
\text { indices of social capital; } \\
\text { however, the products of } \\
\text { these attempts vary in } \\
\text { content, quality, and form }\end{array}$ & $\begin{array}{l}\text { "social capital was conceptually } \\
\text { defined as an investment in } \\
\text { relationships that facilitates exchange } \\
\text { of resources." } \\
\text { "Well-functioning families, according } \\
\text { to Rolland (1994), can be } \\
\text { characterized by a clear sense of the } \\
\text { family unit, with permeable } \\
\text { boundaries between the family and } \\
\text { community. The community includes } \\
\text { both formal (school and health care } \\
\text { systems, for example) and informal } \\
\text { (family, friends, and neighbors) } \\
\text { sources of support." } \\
\text { Exploratory Factor Analysis } \\
23 \text { parents of child with special health } \\
\text { care needs }\end{array}$ \\
\hline
\end{tabular}




\begin{tabular}{|c|c|c|}
\hline . & . & $\begin{array}{l}\text { Study 1- Concept analysis and } \\
\text { exploratory factor analysis } \\
8 \text { Indicators were extracted: } \\
\text { Belonging, Deserving, Role } \\
\text { Satisfaction, Strategic Networking, } \\
\text { Informing, Interacting, } \\
\text { Resourcefulness, and Empathy } \\
\text { Study 2- four focus groups conducted } \\
\text { with a total of } 23 \text { parents } \\
\text { Themes: The System, Trust, } \\
\text { Advocacy, Common Community } \\
\text { Content validity- three family nursing } \\
\text { and measurement experts rated the } \\
\text { relevance of the } 80 \text { items on a } 4 \text { point } \\
\text { ordinal scale= } 38 \text { items were selected } \\
\text { Survey Administration- } 200 \text { sample } \\
\text { size } \\
\text { Psychometric testing- } \\
\text { a set of } 20 \text { items remained for factor } \\
\text { analysis } \\
20 \text { item scale = normal distribution, } \\
\text { cronbach alpha } 0.84, \text { test retest } \\
\text { reliability } 0.90 \text { (p<0.01) } \\
\text { social capital as a concept relevant to } \\
\text { the health of families is an attempt to } \\
\text { integrate what other disciplines have } \\
\text { learned about the significance of } \\
\text { viewing social interactions as assets }\end{array}$ \\
\hline
\end{tabular}




\begin{tabular}{|c|c|c|}
\hline & & $\begin{array}{l}\text { with the existing knowledge of family } \\
\text { strengths and adaptation to illness. } \\
\text { Focusing on family strengths enables } \\
\text { the health care provider to recognize } \\
\text { protective factors that promote health } \\
\text { for the family and child with SHCN. }\end{array}$ \\
\hline $\begin{array}{l}3 . \\
\text { Psychometric properties and } \\
\text { cross-cultural equivalence of } \\
\text { the Arabic Social Capital } \\
\text { Scale: instrument } \\
\text { development study. } \\
\text { Looman, Wendy } \\
\text { Sue. International journal of } \\
\text { nursing studies. v. 46. no. } 1 . \\
\text { p. } 44-53 \\
\text { USA }\end{array}$ & $\begin{array}{l}\text { evaluate the psychometric } \\
\text { properties and cross- } \\
\text { cultural equivalence of the } \\
\text { Arabic translation of the } \\
\text { Social Capital Scale (SCS) }\end{array}$ & $\begin{array}{l}\text { Social capital, defined as an } \\
\text { investment in relationships, is less } \\
\text { about supportive behaviors and more } \\
\text { about the relationships through which } \\
\text { support is exchanged } \\
117 \text { families with children with } \\
\text { special health care needs } \\
\text { The 20-item Arabic SCS } \\
\text { Part 1: survey administered plus } \\
\text { additional measures on demographic } \\
\text { information and parent ratings of the } \\
\text { child's overall health } 0.69 \\
\text { Part 2: Six items were omitted per } \\
\text { item analysis } \\
\text { Part 3: exploratory factor analysis } \\
\text { was conducted on the resulting } 14- \\
\text { item scale. } \\
\text { Cronbach Alpha of } 0.75\end{array}$ \\
\hline
\end{tabular}




\begin{tabular}{|c|c|c|}
\hline & & $\begin{array}{l}\text { cross-cultural equivalence of the } \\
\text { Egyptian and English version of the } \\
\text { SCS was not possible } \\
\text { The } 20 \text {-item Arabic SCS was } \\
\text { administered as part of a written } \\
\text { survey that included additional } \\
\text { measures on demographic } \\
\text { information and parent ratings of the } \\
\text { child's overall health. Six items were } \\
\text { ultimately removed based on item } \\
\text { analysis, and exploratory factor } \\
\text { analysis was conducted on the } \\
\text { resulting } 14 \text {-item scale. } \\
\text { The standardized item alpha } \\
\text { reliability coefficient for the total 14- } \\
\text { item scale was .75. }\end{array}$ \\
\hline $\begin{array}{l}4 . \\
\text { Yaril, A., Nadrian, H., } \\
\text { Rashidian, H., Nedjat, S., } \\
\text { Esmaeilnasab, N., Doroudi, } \\
\text { R.,Hoursan, H. (2013). } \\
\text { Psychometric properties of the } \\
\text { Persian version of Social } \\
\text { Capital Questionnaire in Iran. } \\
\text { Medical Journal of the Islamic } \\
\text { Republic of Iran. 28:17. } \\
\text { Iran }\end{array}$ & $\begin{array}{l}\text { investigate the } \\
\text { psychometric properties of } \\
\text { Onyx and Bullen's } \\
\text { instrument among a } \\
\text { sample of medical science } \\
\text { students in Tehran } \\
\text { University of Medical } \\
\text { Sciences, Iran and to } \\
\text { compare the factor } \\
\text { analysis with findings } \\
\text { from two previous studies } \\
\text { in Australia (15) and the } \\
\text { United States (13). }\end{array}$ & $\begin{array}{l}\text { Onyx and Bullen Social Capital } \\
\text { Questionnaire SCQ } \\
\text { After factor loadings and item-total } \\
\text { correlations } 36 \text { were retained from the } \\
\text { original } 68 \text { items. } \\
\text { Cronbach Alpha } 0.84 \text { for the } 36 \text { items } \\
\text { Item to item-total correlations ranged } \\
\text { from } 0.25-0.45\end{array}$ \\
\hline
\end{tabular}


Table 6.

Evidence based practice papers involving social capital and nursing $(n=4)$ bolded article titles indicate pediatric content

\begin{tabular}{|c|c|c|c|c|}
\hline $\begin{array}{c}\text { AUTHOR } \\
\text { COUNTRY }\end{array}$ & PURPOSE & $\begin{array}{c}\text { DESIGN } \\
\text { POPULATION }\end{array}$ & $\begin{array}{l}\text { DEFINITION OF } \\
\text { SOCIAL CAPITAL } \\
\text { SOCIAL CAPITAL } \\
\text { THEORY }\end{array}$ & ATTRIBUTES \\
\hline $\begin{array}{l}1 . \\
\text { Mason, D.M.(2016). Caring for } \\
\text { the Unseen: Using Linking } \\
\text { Social Capital to Improve } \\
\text { Healthcare Access to Irregular } \\
\text { Migrants in Spain. Journal of } \\
\text { Nursing Scholarship. } 48: 5 \text {, } \\
\text { 448-455. } \\
\text { doi: } 10.1111 \text { jnu.12228 } \\
\text { Spain }\end{array}$ & $\begin{array}{l}\text { "describe a novel } \\
\text { strategy using linking } \\
\text { social capital to provide } \\
\text { healthcare access to } \\
\text { irregular migrants with } \\
\text { low literacy, low } \\
\text { numeracy, and limited } \\
\text { cultural assimilation in a } \\
\text { European metropolitan } \\
\text { area." }\end{array}$ & Adult migrants in Spain. & $\begin{array}{l}\text { "Social capital is the } \\
\text { relationship an individual } \\
\text { has to a group that allows } \\
\text { them to access resources, } \\
\text { such as money, health } \\
\text { care, information, or } \\
\text { services" } \\
\text { Szreter \&Woolcock } \\
\text { Putnam } \\
\text { Linking social capital is } \\
\text { important in the health of } \\
\text { poor communities where } \\
\text { access to formal } \\
\text { institutions, such as } \\
\text { hospitals and clinics, must } \\
\text { be based on trust and } \\
\text { respect in order to improve } \\
\text { accessand health outcomes } \\
\text { (Szreter \& Woolcock, } \\
2004 \text { ). } \\
\text { Nurses as change agents- } \\
\text { harnessing social capital }\end{array}$ & $\begin{array}{l}\text { Trust } \\
\text { Respect } \\
\text { Bonding, bridging, } \\
\text { linking }\end{array}$ \\
\hline
\end{tabular}




\begin{tabular}{|c|c|c|c|c|}
\hline & & & $\begin{array}{l}\text { for the good of the } \\
\text { community }\end{array}$ & \\
\hline $\begin{array}{l}2 . \\
\text { Griffiths, R., Horsfall, J., } \\
\text { Moore, M., Lane, D., Kroon, } \\
\text { V., \& Langdon, R. (2009). } \\
\text { Building social capital with } \\
\text { women in a socially } \\
\text { disadvantaged community. } \\
\text { International Journal of } \\
\text { Nursing Practice. 15(3): 172- } \\
\text { 184. } \\
\text { doi:10.1111/j.1440- } \\
\text { 172X.2009.01742.x } \\
\text { Australia }\end{array}$ & $\begin{array}{l}\text { "report differences } \\
\text { between the baseline } \\
\text { levels of social capital } \\
\text { and follow-up using the } \\
\text { Villawood Icebreaker } \\
\text { survey" }\end{array}$ & $\begin{array}{l}\text { women living in the } \\
\text { Villawood suburb of } \\
\text { Australia }\end{array}$ & $\begin{array}{l}\text { social capital is defined as } \\
\text { containing both individual } \\
\text { and community } \\
\text { components: } \\
\text { behavioral/structural } \\
\text { (participation) and } \\
\text { attitudinal/cognitive (trust) } \\
\text { dimensions. }\end{array}$ & $\begin{array}{l}\text { Participation } \\
\text { Trust } \\
\text { Reciprocity } \\
\text { Individual and } \\
\text { Community aspects }\end{array}$ \\
\hline $\begin{array}{l}\text { 3. } \\
\text { Fielden, J.M. \& Gallagher, } \\
\text { L.M. (2008). Building social } \\
\text { capital in first-time parents } \\
\text { through a group-parenting } \\
\text { program: A questionnaire } \\
\text { survey. International Journal of } \\
\text { Nursing Studies 45:406-417 }\end{array}$ & $\begin{array}{l}\text { identify parent } \\
\text { satisfaction with, } \\
\text { strengths and } \\
\text { weaknesses of, } \\
\text { opportunities to build } \\
\text { social capital, and the } \\
\text { impact of a two-course } \\
\text { pilot health and } \\
\text { relationship focused } \\
\text { Parenting Education } \\
\text { Program-PEPE, } \\
\text { designed for first-time } \\
\text { parents, on the core }\end{array}$ & $\begin{array}{l}\text { Parents enrolled in pilot } \\
\text { health and relationship } \\
\text { program }\end{array}$ & $\begin{array}{l}\text { Social capital involves a } \\
\text { social structure } \\
\text { exemplified by social } \\
\text { interaction between, and } \\
\text { the promotion of social } \\
\text { cohesion amongst, } \\
\text { members of a group or } \\
\text { community } \\
\text { Maternal-child health } \\
\text { nurses/health visitors are } \\
\text { in a prime position to } \\
\text { foster social capital and } \\
\text { help rebuild communities }\end{array}$ & $\begin{array}{l}\text { Social network } \\
\text { Trust } \\
\text { Reciprocity } \\
\text { Shared Values }\end{array}$ \\
\hline
\end{tabular}




\begin{tabular}{|c|c|c|c|}
\hline & $\begin{array}{l}\text { work of the well-child } \\
\text { nurse/health visitor }\end{array}$ & & $\begin{array}{l}\text { within which they work to } \\
\text { enhance parenting } \\
\text { outcomes. } \\
\text { Putnam } \\
\text { Stone } \\
\text { Grootaert }\end{array}$ \\
\hline $\begin{array}{l}4 . \\
\text { Harris FM, Maxwell M, } \\
\text { O'Connor RC, Coyne J, } \\
\text { Arensman E, Székely A, } \\
\text { Gusmão R, Coffey C, Costa S, } \\
\text { Cserháti Z, Koburger N, van } \\
\text { Audenhove C, McDaid D, } \\
\text { Maloney J, Värnik P, Hegerl } \\
\text { U.(2013). Developing social } \\
\text { capital in implementing a } \\
\text { complex intervention: a process } \\
\text { evaluation of the early } \\
\text { implementation of a suicide } \\
\text { prevention intervention in four } \\
\text { European countries. BMC } \\
\text { Public Health 13(158):1471- } \\
2458 \\
\text { UK }\end{array}$ & $\begin{array}{l}\text { Multi-level suicide } \\
\text { prevention plan } \\
\text { 1. engage relevant } \\
\text { regional stakeholders } \\
\text { and create local, } \\
\text { collaborative networks } \\
\text { with the intention of } \\
\text { planning for sustainable } \\
\text { activity in the event that } \\
\text { effectiveness of the } \\
\text { intervention was } \\
\text { demonstrated } \\
\text { 2. explores the role of } \\
\text { advisory groups in } \\
\text { stakeholder engagement } \\
\text { and how different } \\
\text { models of engagement } \\
\text { both influenced } \\
\text { implementation and the } \\
\text { potential for capacity } \\
\text { building and } \\
\text { sustainability of an } \\
\text { optimized suicide } \\
\text { prevention program in } \\
\text { four European countries }\end{array}$ & $\begin{array}{l}\text { Each country was } \\
\text { treated as a case study } \\
\text { and data col- lection } \\
\text { followed a longitudinal } \\
\text { approach designed to } \\
\text { capture the process of } \\
\text { change }\end{array}$ & $\begin{array}{l}\text { Bourdieu, Putnam } \\
\text { Social capital is defined as } \\
\text { "the features of social } \\
\text { organization, such as } \\
\text { networks, norms and trust } \\
\text { that facilitate coordination } \\
\text { and cooperation for mutual } \\
\text { benefit" [12: p35]. By } \\
\text { extension, this social } \\
\text { capital is then tapped into } \\
\text { and shared by network } \\
\text { participants. }\end{array}$ \\
\hline
\end{tabular}


Table 7.

Mixed Methods studies involving social capital and nursing $(n=2)$ bolded article titles indicate pediatric content

\begin{tabular}{|c|c|c|c|c|}
\hline AUTHOR, COUNTRY & PURPOSE & $\begin{array}{c}\text { DEFINITION OF } \\
\text { SOCIAL CAPITAL } \\
\text { SOCIAL CAPITAL } \\
\text { THEORY }\end{array}$ & DISCUSSION & ATTRIBUTES \\
\hline $\begin{array}{l}1 . \\
\text { Coll-Planas, L. Del } \\
\text { Valle Gomez, G., } \\
\text { Bonilla, P., Masat, T., } \\
\text { Puig, T., \& } \\
\text { Monteserin, R. (2017). } \\
\text { Promoting social } \\
\text { capital to alleviate } \\
\text { loneliness and } \\
\text { improve health among } \\
\text { older people in Spain. } \\
\text { Health and Social } \\
\text { Care in the } \\
\text { Community 25(1), } \\
\text { 145-157 } \\
\text { doi: } \\
\text { 10.1111/hsc.12284 } \\
\text { Spain }\end{array}$ & $\begin{array}{l}\text { 1. explore the } \\
\text { feasibility of the } \\
\text { intervention in mixed } \\
\text { rural- urban and } \\
\text { urban areas of diverse } \\
\text { socioeconomic levels. } \\
\text { 2. assess the } \\
\text { immediate and } \\
\text { long-term effects of } \\
\text { this intervention } \\
\text { among older } \\
\text { participants on: (i) } \\
\text { loneliness; (ii) } \\
\text { structural and cog- } \\
\text { nitive aspects of } \\
\text { individual social } \\
\text { capital (i.e. partici- } \\
\text { pation and social } \\
\text { support); (iii) } \\
\text { perceived health, }\end{array}$ & $\begin{array}{l}\text { "social capital is an } \\
\text { umbrella concept } \\
\text { that involves } \\
\text { individual (family } \\
\text { and friends) and } \\
\text { collective social } \\
\text { resources (e.g. } \\
\text { neigh- } \\
\text { borhoods), their } \\
\text { structural (e.g. } \\
\text { social network, } \\
\text { social contacts and } \\
\text { participation) and } \\
\text { cognitive aspects } \\
\text { (e.g. social support } \\
\text { and sense of } \\
\text { belonging" }\end{array}$ & $\begin{array}{l}\text { two components of social capital } \\
\text { are crucial to tackle loneliness } \\
\text { among older people: social } \\
\text { support as a cognitive resource and } \\
\text { social participation as a structural } \\
\text { one } \\
\text { A policy debate should be opened } \\
\text { about the roles of primary health } \\
\text { and social care, community } \\
\text { services, and their responsibilities } \\
\text { and priorities in } \\
\text { implementing care co-ordination } \\
\text { and programs. } \\
\text { Create a loneliness intervention }\end{array}$ & $\begin{array}{l}\text { Strength of } \\
\text { connections- } \\
\text { bonding, } \\
\text { bridging, linking } \\
\text { Social networks } \\
\text { Support } \\
\text { Belonging }\end{array}$ \\
\hline
\end{tabular}




\begin{tabular}{|c|c|c|c|c|}
\hline & $\begin{array}{l}\text { health-related quality } \\
\text { of life, depressive } \\
\text { symptoms } \\
\text { and the use of } \\
\text { anxiolytics and } \\
\text { antidepressants; and } \\
\text { (iv) the use of health } \\
\text { services. }\end{array}$ & & & \\
\hline $\begin{array}{l}2 . \\
\text { Baheiraei1, A., } \\
\text { Bakouei, F., } \\
\text { Mohammadi, E., } \\
\text { Majdzadeh, R., \& } \\
\text { Hosseni, M. (2016). } \\
\text { Association between } \\
\text { social capital and } \\
\text { health in women of } \\
\text { reproductive age: a } \\
\text { population-based } \\
\text { study. Global Health } \\
\text { Promotion Vol. 23, } \\
\text { No. } 4\end{array}$ & $\begin{array}{l}\text { determine social } \\
\text { capital status and its } \\
\text { association with } \\
\text { health in } \\
\text { reproductive-age } \\
\text { women in Tehran } \\
\text { (capital city of Iran) } \\
\text { with its specific } \\
\text { social-cultural } \\
\text { characteristics. }\end{array}$ & $\begin{array}{l}\text { Putnam, Coleman } \\
\text { The World Bank } \\
\text { introduced an } \\
\text { instrument for } \\
\text { measuring social } \\
\text { capital through } \\
\text { which a set of key } \\
\text { and central } \\
\text { questions are } \\
\text { extracted from } \\
\text { previous studies } \\
\text { conducted on social } \\
\text { capital, and this is } \\
\text { the instrument that } \\
\text { is used in this study }\end{array}$ & $\begin{array}{l}\text { dimensions of social capital } \\
\text { manifestations (groups and } \\
\text { networks, trust and solidarity, } \\
\text { collective action and cooperation) } \\
\text { can potentially lead to the } \\
\text { dimensions of social capital } \\
\text { outcomes (social cohesion and } \\
\text { inclusion, and empowerment and } \\
\text { political action), which in turn } \\
\text { affect health inequities, after } \\
\text { controlling for socio-demographic } \\
\text { differences } \\
\text { A greater focus on social capital's } \\
\text { role on health promotion and health } \\
\text { policies is required. Moreover, the } \\
\text { findings showed that women with } \\
\text { higher financial or human capital } \\
\text { (e.g. through education) experience } \\
\text { better health. }\end{array}$ & $\begin{array}{l}\text { Social networks } \\
\text { Trust } \\
\text { Solidarity } \\
\text { Collective action } \\
\text { Cooperation } \\
\text { Value of } \\
\text { communications } \\
\text { Social Cohesion } \\
\text { Empowerment } \\
\text { Political Action }\end{array}$ \\
\hline
\end{tabular}


Table 8 .

Quantitative Measurement Modalities for Social Capital in the Nursing Literature

$\begin{array}{ll}\text { Mixed indicators, scales, surveys } & 16\end{array}$

Social Capital Questionnaire- Greek 4

Social Capital Scale - English 2

Social Capital in Organizations Variable 2

Social Capital Outcomes for Nurses - Korean 2

Shortell Organizational Culture Scale 1

Borg Instrument (in Danish) 1

Social Capital Outcomes for Nurses - English 1

Looman's Social Capital Scale for Children with Special Health Care Needs 1

British General Household Survey of Social Capital 1

Workplace Social Capital - Japanese 1

Social Capital in Hospitals Variable 1 
Table 9.

Attributes of social capital within the context of nursing

\begin{tabular}{|c|c|}
\hline Attribute (62) & Frequency \\
\hline Trust & 52 \\
\hline Social Network & 39 \\
\hline Reciprocity & 33 \\
\hline Strength of Connections (Bonding, Bridging, Linking) & 26 \\
\hline Social Norms & 20 \\
\hline Participation & 18 \\
\hline Values & 13 \\
\hline Belonging & 12 \\
\hline Support & 10 \\
\hline Communication & 8 \\
\hline Social Cohesion & 8 \\
\hline Solidarity & 6 \\
\hline Safety & 5 \\
\hline Cooperation & 5 \\
\hline Empowerment & 4 \\
\hline Engagement & 4 \\
\hline Collective Action & 4 \\
\hline Mutual Aid & 4 \\
\hline Political Action & 3 \\
\hline Trustworthiness & 3 \\
\hline Inclusion & 3 \\
\hline Frequency of Social Interactions & 2 \\
\hline Shared Assets & 2 \\
\hline Shared Ways of Knowing & 2 \\
\hline Social Interaction & 2 \\
\hline Shared Vision & 2 \\
\hline Altruism & 2 \\
\hline Tolerance & 2 \\
\hline Mutual Benefit & 2 \\
\hline Sense of Community & 2 \\
\hline
\end{tabular}


Table 10.

Critical Attributes of Social Capital: Cognitive Domain

\begin{tabular}{|c|c|c|}
\hline Attribute & $\begin{array}{l}\text { Definition } \\
\text { www.merriam-webster.com }\end{array}$ & $\begin{array}{l}\text { Synonyms } \\
\text { www.thesaurus.com }\end{array}$ \\
\hline $\begin{array}{l}\text { Trust } \\
(58)\end{array}$ & $\begin{array}{l}\text { Assured reliance on the ability, } \\
\text { strength, or truth of something or } \\
\text { someone. }\end{array}$ & $\begin{array}{l}\text { Assurance, confidence, hope, } \\
\text { certainty, faith, reliance }\end{array}$ \\
\hline \multirow[t]{2}{*}{$\begin{array}{l}\text { Reciprocity } \\
(46)\end{array}$} & $\begin{array}{l}\text { Quality involving mutual action, } \\
\text { dependence, or influence. }\end{array}$ & \multirow[t]{2}{*}{ Cooperation, exchange, mutuality } \\
\hline & $\begin{array}{l}\text { Willingness to help others with the } \\
\text { intent to receive something in return. }\end{array}$ & \\
\hline \multirow[t]{2}{*}{$\begin{array}{l}\text { Shared Values } \\
(21)\end{array}$} & The worth of something. & \multirow[t]{2}{*}{$\begin{array}{l}\text { Shared ethics, morals, character, } \\
\text { attitudes, beliefs, ideals, scruples }\end{array}$} \\
\hline & Common values & \\
\hline \multirow{2}{*}{$\begin{array}{l}\text { Solidarity } \\
(21)\end{array}$} & Perceived social support, unity. & \multirow{2}{*}{$\begin{array}{l}\text { togetherness, consensus, } \\
\text { uniformity, comradery, teamwork, } \\
\text { unification, harmony, support, } \\
\text { alliance }\end{array}$} \\
\hline & $\begin{array}{l}\text { Unified group consisting of similar } \\
\text { interests, standards, objectives. }\end{array}$ & \\
\hline $\begin{array}{l}\text { Social Norms } \\
(20)\end{array}$ & $\begin{array}{l}\text { Binding force among networks or } \\
\text { groups of people that regulates or } \\
\text { guides acceptable behavior within the } \\
\text { group }\end{array}$ & $\begin{array}{l}\text { Rules, criteria, model, pattern, } \\
\text { benchmark }\end{array}$ \\
\hline $\begin{array}{l}\text { Safety } \\
(5)\end{array}$ & $\begin{array}{l}\text { Condition of being free or safe from } \\
\text { danger, harm, loss, or injury }\end{array}$ & $\begin{array}{l}\text { Security, freedom, asylum, } \\
\text { defense, shelter }\end{array}$ \\
\hline
\end{tabular}


Table 11.

Critical Attributes of Social Capital: Behavioral Domain

\begin{tabular}{|c|c|c|}
\hline Attribute & $\begin{array}{l}\text { Definition } \\
\text { www.merriam-webster.com }\end{array}$ & $\begin{array}{l}\text { Synonyms } \\
\text { www.thesaurus.com }\end{array}$ \\
\hline $\begin{array}{l}\text { Participation } \\
(26)\end{array}$ & $\begin{array}{l}\text { Act of engaging or participating in } \\
\text { an activity as an individual or as a } \\
\text { group. }\end{array}$ & $\begin{array}{l}\text { Attending, joining in, doing, aiding, } \\
\text { assisting }\end{array}$ \\
\hline $\begin{array}{l}\text { Communication } \\
\text { (8) }\end{array}$ & $\begin{array}{l}\text { Process of exchanging information } \\
\text { via signs, symbols, or behaviors. }\end{array}$ & $\begin{array}{l}\text { Conversation, contact, connection, } \\
\text { messaging, delivering, linking, } \\
\text { transmitting }\end{array}$ \\
\hline $\begin{array}{l}\text { Frequency of } \\
\text { Social } \\
\text { Interaction } \\
\text { (4) }\end{array}$ & $\begin{array}{l}\text { Amount of times interacting with a } \\
\text { person or group }\end{array}$ & \\
\hline
\end{tabular}


Table 12.

\section{Codebook/Variable Tables}

\begin{tabular}{lcc}
\hline Definition of Variable & Label & Measurement \\
\hline $\begin{array}{l}\text { Type of detailed topical } \\
\text { questionnaire }\end{array}$ & $\begin{array}{c}\text { FORMTYPE } \\
\text { p.1 }\end{array}$ & $\begin{array}{c}\text { If AGE_YEARS }=0-5, \text { then } \\
\text { FORMTYPE }=\text { T1 } 1 \text { LE: }\end{array}$ \\
State FIPS Code & FIPSST & $1-56$ state codes \\
& p. 1 & California code $=6$ \\
\end{tabular}

Dependent Variable

\begin{tabular}{|c|c|c|}
\hline Variable & Label & Measurement \\
\hline $\begin{array}{l}\text { Doctor (Health care provider) } \\
\text { visit how many times over the } \\
\text { past } 12 \text { months }\end{array}$ & K4Q2OR & $\begin{array}{l}1=\text { no visits } \\
2=1 \text { visit } \\
3=2 \text { or more visits }\end{array}$ \\
\hline $\begin{array}{l}\text { Preventative health care } \\
\text { utilization over the past } 12 \\
\text { months }\end{array}$ & PCHU & $\begin{array}{l}0=\text { no visits } \\
1=\text { visits }\end{array}$ \\
\hline
\end{tabular}

Sociodemographic and Culture Characteristics

\begin{tabular}{|c|c|c|}
\hline Variable & Label & Measurement \\
\hline $\begin{array}{l}\text { Age of selected child in } \\
\text { years }\end{array}$ & SC_AGE_YEARS & $0-5$ years old \\
\hline $\begin{array}{l}\text { Family structure } \\
\text { Survey instrument item } \\
\text { number for children } 0-5 \\
\text { years: J1 }\end{array}$ & FAMILY & $\begin{array}{l}1=\text { Two biological/adoptive parents, } \\
\text { currently married } \\
2=\text { Two biological/adoptive parents, not } \\
\text { currently married } \\
3=\text { Two parents (at least one not } \\
\text { biological/adoptive), currently } \\
\text { married } \\
4=\text { Two parents (at least one not } \\
\text { biological/adoptive), not currently } \\
\text { married } \\
5=\text { One mother, currently married } \\
\text { (living apart) or formerly married } \\
6=\text { One mother, never married } \\
7=\text { Other, currently married or formerly } \\
\text { married } \\
8=\text { Other, never married } \\
9=\text { Other, no parent in household }\end{array}$ \\
\hline
\end{tabular}




\begin{abstract}
Number of people living at home that are family members

Family is defined as anyone related to this child by blood, marriage, adoption, or through foster care.

\section{Child sex \\ Did you receive emotional support from: Place of worship or religious leader?}

Since child was born, how often has it been very hard to get by on your family's income - hard to cover the basics like food or housing? [SEEP:

Highest Level of Education among Reported Adults in household, Detail

Insurance type

Child born in the USA

\section{Adult1 born in USA \\ (Survey Respondent)}

Parental nativity $=$ generational status of household Survey instrument item number for children 0-5 years: H1,J4;

Parental nativity was defined based on 3 questions: relationship to
FAMCOUNT

$1-8$

$$
\begin{array}{ll}
\text { SC_SEX } & 1=\text { male } \\
& 2=\text { female } \\
\text { EMOSUPWOR } & 1=\text { Yesis } \\
& 2=\text { No }
\end{array}
$$

ACE1

$$
\begin{aligned}
& 1=\text { Neveris } \\
& 2=\text { Rarely } \\
& 3=\text { Somewhat often } \\
& 4=\text { Very often }
\end{aligned}
$$

HIGRADE_TVIS

$1=$ Less than high schoolisep:

$2=$ High school/GED/vocational

$3=$ Some college

$4=$ College degree or higher

INSTYPE

$1=$ Public only

$2=$ Private only's[s:

$3=$ Private and publicisẹp:

$4=$ Insurance type unspecified

$5=$ Not insured

BORNUSA

$1=$ born in USA

$2=$ not born in USA

A1_BORNUSA $\quad 1=$ born in USA

$2=$ not born in USA

HOUSE_GEN

This variable is defined following the Census definition of household generational status: 1 = First generation household: child born abroad, no parent in the household born in the US $2=$ Second generation household: at least one parent in the household born abroad, child born in US or child born abroad, one parent in the household 
the child from 2 adults in the household who are the child's primary caregivers (A\#_RELATIONSHIP), place where the adult(s) was(were) born (A\#BORN), and whether the child was born in US (BORNUSA). Children's parent includes biological or adoptive, step or foster parents.

Primary HH language

What is the child's race?

SC_RACE_R

p. 2

S1 born in US and another parent in the household born abroad) $3=$ Third-or-higher generation household: All parents in the household born in US, place of child's birth irrelevant $4=$ Child is born in US, not parents are listed
Hispanic Origin of Selected Child

Is the child of Hispanic, Latino, or Spanish origin?
SC_HISPANIC_R p. 3

S1

Race_eth \\ New variable for child \\ race/ethnicity \\ Combines SC_RACE_R \\ and SC_HISPANIC_R
}

$$
\begin{aligned}
& 1=\text { Non-Hispanic white } \\
& 2=\text { Non-Hispanic Black } \\
& 3=\text { Non-Hispanic Asian } \\
& 4=\text { Other } \\
& 5=\text { Hispanic }
\end{aligned}
$$


Family Social Capital: Cognitive Domain

\begin{tabular}{l}
\hline Variable Query \\
\hline In general, how well do \\
you feel you are handling \\
the day to day demands of \\
raising children? \\
Recode \\
DemandsRaisingChildren
\end{tabular}

To what extent do you agree with these statements about your neighborhood or community?

This child is safe in our neighborhood

\section{Recode ChildSafe}

Label
K8Q30
p.58

$1=$ Very wellis $\quad$ Solidarity, Shared

$2=$ Somewhat well Values

$3=$ Not very wellispep

$4=$ Not at all

$4=$ Very wellis

$3=$ Somewhat well

$2=$ Not very wellispep

$1=$ Not at all

K10Q40_R p.65

1 = Definitely

agree

2 = Somewhat

agree

$3=$ Somewhat

disagree

4 = Definitely

disagree

$$
\begin{aligned}
& 4=\text { Definitely } \\
& \text { agree } \\
& 3=\text { Somewhat } \\
& \text { agree } \\
& 2 \text { = Somewhat }
\end{aligned}
$$

During the past 12 months, was there someone that

K8Q35

p.59

you could turn to for dayto-day emotional support with parenting or raising children? ?[5ep?
$1=$ Yesis

$2=$ No
Safety

FSC Attribute

Safety

\section{Recode \\ EmoSupport}

$2=$ Yes

$1=$ No

When your family faces problems, how often are you likely to Work together to solve our problems
Reciprocity, Trust, Solidarity

\author{
Solidarity, \\ Reciprocity, Trust, \\ Shared Values
}




\section{Recode \\ WKTOGETHER}

$4=$ All of the

time

$3=$ Most of the time

$2=$ Some of the

time

$1=$ None of the

time

Family Social Capital: Behavioral Domain

\begin{tabular}{|c|c|c|c|}
\hline Variable Query & Variable Name & Measurement & FSC Attribute \\
\hline $\begin{array}{l}\text { How many days over } \\
\text { the past week does the } \\
\text { family eat together? }\end{array}$ & $\begin{array}{l}\text { K8Q11 } \\
\text { p.61 }\end{array}$ & $\begin{array}{l}1=\text { never } \\
2=1-3 \text { days per week } \\
3=4-6 \text { days per week } \\
4=\text { every day }\end{array}$ & Participation \\
\hline $\begin{array}{l}\text { How many days over } \\
\text { the past week is the } \\
\text { child read to? }\end{array}$ & $\begin{array}{l}\text { K6Q60_R } \\
\text { p.57 }\end{array}$ & $\begin{array}{l}1=\text { never } \\
2=1-3 \text { days per week } \\
3=4-6 \text { days per week } \\
4=\text { every day }\end{array}$ & Participation \\
\hline $\begin{array}{l}\text { How many days over } \\
\text { the past week include } \\
\text { singing stories or } \\
\text { telling stories to the } \\
\text { child? }\end{array}$ & $\begin{array}{l}\text { K6Q61_R } \\
\text { p.58 }\end{array}$ & $\begin{array}{l}1=\text { never } \\
2=1-3 \text { days per week } \\
3=4-6 \text { days per week } \\
4=\text { every day }\end{array}$ & Participation \\
\hline $\begin{array}{l}\text { How often does the } \\
\text { child go to bed at the } \\
\text { same time on } \\
\text { weeknights? }\end{array}$ & $\begin{array}{l}\text { BEDTIME } \\
\text { p. } 56\end{array}$ & $\begin{array}{l}1=\text { Always } \\
2=\text { Usually } \\
3=\text { Sometimes } \\
4=\text { Rarely } \\
5=\text { Never }\end{array}$ & Social Norms \\
\hline $\begin{array}{l}\text { Recode } \\
\text { EnforcedBedtime }\end{array}$ & & $\begin{array}{l}5=\text { Always } \\
4=\text { Usually } \\
3=\text { Sometimes } \\
2=\text { Rarely } \\
1=\text { Never }\end{array}$ & \\
\hline
\end{tabular}


Table 13.

Child and family sociodemographic characteristics $(N=257)$

\begin{tabular}{|c|c|c|c|}
\hline & $\mathrm{n}$ & $\%$ & Valid \% \\
\hline \multicolumn{4}{|c|}{ Age of child in years } \\
\hline 0 & 26 & & 10.1 \\
\hline 1 & 34 & & 13.2 \\
\hline 2 & 45 & & 17.5 \\
\hline 3 & 48 & & 18.7 \\
\hline 4 & 56 & & 21.8 \\
\hline 5 & 48 & & 18.7 \\
\hline
\end{tabular}

\begin{tabular}{lccc}
\hline Gender of child & & & \\
\hline Female & 112 & & 43.6 \\
\hline Male & 145 & & 56.4 \\
\hline Caregiver marital status & & & \\
\hline Married & 191 & & 87.1 \\
\hline Not married & 57 & & 12.9 \\
\hline Missing & 9 & & \\
\hline Members in family & & & \\
\hline 2 & 5 & 1.9 & 2.1 \\
\hline 3 & 80 & 31.1 & 33.1 \\
\hline 4 & 96 & 37.4 & 39.7 \\
\hline 5 & 39 & 15.2 & 16.1 \\
\hline 6 & 16 & 6.2 & 6.6 \\
\hline 7 & 2 & 0.8 & 0.8 \\
\hline 8 & 4 & 1.6 & 1.7 \\
\hline Missing & 15 & 5.8 & \\
\hline
\end{tabular}

\section{Emotional support from place of worship}

\begin{tabular}{lccc} 
Yes & 47 & 18.3 & 24.5 \\
\hline No & 145 & 56.4 & 75.5 \\
\hline Missing & 65 & 25.3 &
\end{tabular}

Hard to cover basics

\begin{tabular}{lccc}
\hline Never & 150 & 58.4 & 60.0 \\
\hline Rarely & 62 & 24.1 & 24.8 \\
\hline Somewhat often & 30 & 11.7 & 12.0 \\
\hline Very often & 8 & 3.1 & 3.2 \\
\hline Missing & 7 & 2.7 & \\
\hline
\end{tabular}

Highest level of adult education in family

\begin{tabular}{lcc}
\hline High school & 8 & 3.1 \\
\hline High school, GED, vocational & 18 & 7 \\
\hline Some college & 42 & 16.3 \\
College degree or higher & 179 & 72.5
\end{tabular}




\begin{tabular}{lcc}
\hline Insurance type & & \\
\hline Public & 51 & 19.8 \\
\hline Private & 191 & 74.3 \\
\hline Public and private & 3 & 1.2 \\
\hline Not specified & 3 & 1.2 \\
\hline No insurance & 9 & 3.5 \\
\hline
\end{tabular}

Note: $\%=$ actual reported data (includes missing data), Valid $\%=$ takes missing data into account $=100 \%$ 
Table 14.

Family culture characteristics $(N=257)$

\begin{tabular}{lccc}
\hline & $\mathrm{n}$ & $\%$ & Valid \% \\
\hline Child born in the USA & & & \\
Yes & 245 & 95.3 & 96.1 \\
No & 10 & 3.9 & 3.9 \\
Missing & 2 & 0.8 & 100 \\
Adult caregiver respondent(A1) born in USA & & & \\
Yes & 158 & 61.5 & 63.2 \\
No & 92 & 35.8 & 36.8 \\
Missing & 7 & 2.7 & 100 \\
Household generational status/parental nativity & & & \\
First generation & 10 & 3.9 & 3.9 \\
Second generation & 97 & 37.7 & 38.2 \\
Third generation & 128 & 49.8 & 50.4 \\
Other & 19 & 7.4 & 7.5 \\
Missing & 3 & 1.2 & 100 \\
Primary language at home & & & \\
English & 199 & 77.4 & 79.3 \\
Spanish & 24 & 9.3 & 9.6 \\
Other & 28 & 10.9 & 11.2 \\
Missing & 6 & 2.3 & 100 \\
Child race/ethnicity & & & \\
Non-Hispanic white & 87 & & 33.9 \\
Non-Hispanic Black & 7 & & 2.7 \\
Non-Hispanic Asian & 55 & & 21.4 \\
Other & 35 & & 13.6 \\
Hispanic & 73 & & 28.4 \\
\hline
\end{tabular}

Note: $\%=$ actual reported data (includes missing data)

Valid $\%=$ takes missing data into account $=100 \%$ 
Table 15a.

Family social capital: Cognitive domain $(N=257)$

\begin{tabular}{lccc}
\hline & $\mathrm{n}$ & $\%$ & Valid \% \\
\hline Demands of raising a child & & & \\
Very well & 159 & 61.9 & 62.8 \\
Somewhat well & 91 & 35.4 & 36.0 \\
Not very well & 3 & 1.2 & 1.2 \\
Not at all & 0 & 0 & 0 \\
Missing & 4 & 1.6 & 100 \\
Child safe in neighborhood & & & \\
Definitely agree & 148 & 57.6 & 59 \\
Somewhat agree & 81 & 31.5 & 32.3 \\
Somewhat disagree & 17 & 6.6 & 6.8 \\
Definitely disagree & 5 & 1.9 & 2.0 \\
Missing & 6 & 2.3 & 100 \\
Someone to turn to for support & & & \\
Yes & 193 & 75.1 & 76.3 \\
No & 60 & 23.3 & 23.7 \\
Missing & 4 & 1.6 & 100 \\
Works together on problems & & & \\
All of the time & 140 & 54.5 & 55.8 \\
Most of the time & 92 & 35.8 & 36.7 \\
Some of the time & 15 & 5.8 & 6.0 \\
None of the time & 4 & 1.6 & 1.6 \\
Missing & 6 & 2.3 & 100 \\
\hline & & & \\
\hline
\end{tabular}

Note: $\%=$ actual reported data (includes missing data), Valid $\%=$ takes missing data into account $=100 \%$ 
Table 15b.

Family social capital: Behavioral domain $(N=257)$

\begin{tabular}{|c|c|c|c|}
\hline & $\mathrm{n}$ & $\%$ & Valid \% \\
\hline \multicolumn{4}{|c|}{ Days per week eating together } \\
\hline Every day & 124 & 48.2 & 49.4 \\
\hline 4-6 days per week & 77 & 30 & 30.7 \\
\hline 1-3 days per week & 45 & 17.5 & 17.9 \\
\hline Never & 5 & 1.9 & 2 \\
\hline Missing & 6 & 2.3 & 100 \\
\hline \multicolumn{4}{|c|}{ Days per week reading to child } \\
\hline Every day & 103 & 40.1 & 41 \\
\hline 4-6 days per week & 54 & 21.0 & 21.5 \\
\hline 1-3 days per week & 81 & 31.5 & 32.3 \\
\hline Never & 13 & 5.1 & 5.2 \\
\hline Missing & 6 & 2.3 & 100 \\
\hline \multicolumn{4}{|c|}{$\begin{array}{l}\text { Days per week } \\
\text { singing/storytelling }\end{array}$} \\
\hline Every day & 130 & 50.6 & 51.6 \\
\hline 4-6 days per week & 45 & 17.5 & 17.9 \\
\hline 1-3 days per week & 63 & 24.5 & 25 \\
\hline Never & 14 & 5.4 & 5.6 \\
\hline Missing & 5 & 1.9 & 100 \\
\hline \multicolumn{4}{|c|}{ Regular bedtime on weeknights } \\
\hline Always & 95 & & 37.8 \\
\hline Usually & 132 & & 52.6 \\
\hline Sometimes & 17 & & 6.8 \\
\hline Rarely & 5 & & 2.8 \\
\hline Never & 2 & & 0.8 \\
\hline
\end{tabular}

$\%=$ actual reported data (includes missing data)

Valid $\%=$ takes missing data into account $=100 \%$ 
Table 16a.

Visits with physician or other health care provider for preventative health care services $(N=257)$

\begin{tabular}{lcc}
\hline & $\mathrm{n}$ & Valid \% \\
\hline More than 2 visits & 114 & 2.3 \\
1 visit & 114 & 44.4 \\
No visits & 6 & 44.4 \\
Total & 234 & \\
Missing & 23 & 8.9 \\
Total & 257 & 100 \\
\hline
\end{tabular}

Table 16b.

Visits with physician or other health care provider for preventative services per age of child

( $\mathrm{N}=257$ )

\begin{tabular}{|c|c|c|c|}
\hline & $\mathrm{n}$ & $\%$ & Valid \% \\
\hline \multicolumn{4}{|c|}{ Less than 1 year old $(0-1)$} \\
\hline No visits & 1 & 3.8 & 4.5 \\
\hline 1 visit & 3 & 11.5 & 13.6 \\
\hline 2 or more visits & 18 & 69.2 & 81.8 \\
\hline Missing & 4 & 15.4 & \\
\hline Total & 26 & & 100 \\
\hline \multicolumn{4}{|c|}{ Less than 2 years old (1-2) } \\
\hline No visits & 1 & & 2.9 \\
\hline 1 visit & 5 & & 14.7 \\
\hline 2 or more visits & 28 & & 82.4 \\
\hline Total & 34 & & 100 \\
\hline \multicolumn{4}{|c|}{ Less than 3 years old $(2-3)$} \\
\hline No visits & 1 & 2.2 & 2.4 \\
\hline 1 visit & 11 & 24.4 & 26.8 \\
\hline 2 or more visits & 29 & 64.4 & 70.7 \\
\hline Missing & 4 & 8.9 & \\
\hline Total & 45 & & 100 \\
\hline \multicolumn{4}{|c|}{ Less than 4 years old (3-4) } \\
\hline No visits & 2 & 4.2 & 4.5 \\
\hline 1 visit & 31 & 64.6 & 70.5 \\
\hline 2 or more visits & 11 & 22.9 & 25 \\
\hline Missing & 4 & 8.3 & \\
\hline Total & 48 & & 100 \\
\hline
\end{tabular}




\section{Less than 5 years old (4-5)}

No visits

1 visit

$\begin{array}{lll}0 & 0 & 0\end{array}$

2 or more visits

$\begin{array}{lll}38 & 67.9 & 74.5\end{array}$

Missing

$\begin{array}{lll}13 & 23.2 & 25.5\end{array}$

Total

$5 \quad 8.9$

$56 \quad 100$

\section{Less than 6 years old (5-6)}

No visits

$\begin{array}{lll}1 & 2.1 & 2.4\end{array}$

1 visit

$\begin{array}{lll}26 & 54.2 & 61.9\end{array}$

2 or more visits

$\begin{array}{lll}15 & 31.1 & 35.7\end{array}$

Missing

$\begin{array}{ll}6 & 12.5\end{array}$

Total

48

100

Note: $\%=$ actual reported data (includes missing data)

Valid $\%=$ takes missing data into account $=100 \%$

Table 16c.

Preventative health care utilization per age recommendations $(N=257)$

\begin{tabular}{lllllllll}
\hline Years of age & 0 & 1 & 2 & 3 & 4 & 5 & Total per age in years & Valid \% \\
\hline Utilizing & 18 & 28 & 29 & 42 & 51 & 41 & 209 & 81.3 \\
Not utilizing & $\mathbf{4}$ & $\mathbf{6}$ & $\mathbf{1 2}$ & $\mathbf{2}$ & $\mathbf{0}$ & $\mathbf{1}$ & $\mathbf{2 5}$ & $\mathbf{9 . 7}$ \\
Total & 22 & 34 & 41 & 44 & 51 & 42 & 234 & $100(\mathrm{~N}=257)$ \\
Missing & 4 & 0 & 4 & 4 & 5 & 6 & 23 & \\
\hline
\end{tabular}

$\underline{0-2}$ years old

2 or more visits is utilizing preventative health care services

1 or no visits is not utilizing preventative health care services

$\underline{3-5 \text { years old }}$

1 or more visits is utilizing preventative health care services

No visits is not utilizing preventative health care services 
Table 17a.

Bivariate analysis of preventative visits with health care provider over past 12 months and sociodemographic characteristics

\begin{tabular}{lccc}
\hline $\begin{array}{l}\text { Relationship tested between } \\
\text { preventative health care utilization and } \\
\text { sociodemographic characteristic }\end{array}$ & Pearson chi square & $\begin{array}{c}\text { Fisher's exact } \\
\text { probability } \\
(2 \text { tailed p-value) }\end{array}$ & $\begin{array}{c}\text { Cramer' V } \\
\text { (exact significance) }\end{array}$ \\
\hline Age of child & $61.8(0.000)^{*}$ a & & .364 \\
Gender of child & $3.56(.169)$ & .127 \\
Parent marital structure & $7.48(.664)$ & .123 \\
Members living at home & $10.50(.745)$ & .118 \\
Church for emotional support & $2.70(.221)$ & .118 \\
Hard to get by & $2.12(.922)$ & .053 \\
Highest level adult education & $11.00(.068)$ & .167 \\
Insurance type & $11.02(.233)$ & .154 \\
Child born in USA & $1.53(.300)$ & .082 \\
Adult1 born in USA & $.817(.695)$ & .054 \\
Household generational status & $4.809(.539)$ & .107 \\
Primary language at home & $6.101(.153)$ & .104 \\
Child race/ethnicity & $15.83(.024) *$ & .053 \\
\hline
\end{tabular}

$* \mathrm{p}<0.05$

$\mathrm{a}=$ asymptotic significance $(2$ tailed $)$ 
Table 17b.

Bivariate correlation matrix for family social capital variables

\begin{tabular}{|c|c|c|c|c|c|c|c|}
\hline & 1 & 2 & 3 & 4 & 5 & 6 & 7 \\
\hline \multicolumn{8}{|l|}{$\begin{array}{l}1 \text { Raising } \\
\text { children }\end{array}$} \\
\hline $\begin{array}{l}2 \text { Safe in } \\
\text { neighborhood }\end{array}$ & $.167 * *$ & & & & & & \\
\hline $\begin{array}{l}3 \text { Emotional } \\
\text { support }\end{array}$ & -.039 & .051 & & & & & \\
\hline $\begin{array}{l}4 \text { Work } \\
\text { together }\end{array}$ & $.215^{* *}$ & .121 & $.144^{*}$ & & & & \\
\hline $\begin{array}{l}5 \text { Meals per } \\
\text { week }\end{array}$ & .100 & .065 & -.004 & $.168 * *$ & & & \\
\hline $\begin{array}{l}6 \text { Reading per } \\
\text { week }\end{array}$ & .116 & $.165^{* *}$ & $.240 * *$ & .097 & $.131 *$ & & \\
\hline $\begin{array}{l}7 \text { Stories and } \\
\text { Songs }\end{array}$ & $.141^{*}$ & .098 & $.292 * *$ & $.179 * *$ & $.182 * *$ & $.571 * *$ & \\
\hline $\begin{array}{l}8 \text { Regular } \\
\text { bedtime }\end{array}$ & $.241 * *$ & .116 & .065 & .124 & $.167 * *$ & $.196^{* *}$ & $.139^{*}$ \\
\hline
\end{tabular}

Table 17c.

Bivariate analysis of preventative visits with health care provider over past 12 months and family social capital variables

\begin{tabular}{lc}
\hline & $\begin{array}{c}\text { Preventative health care utilization } \\
\text { (Spearman's rho values) }\end{array}$ \\
\hline Demands raising children & .031 \\
Child safe in neighborhood & -.007 \\
Emotional support raising children & -.042 \\
Work together to solve problems & .050 \\
Days per week eating together & -.048 \\
Days per week reading together & -.035 \\
Days per week- stories and songs & .113 \\
Weeknights with regular bedtime & -.027 \\
\hline
\end{tabular}


Appendix A: Levels and bonds of social capital

Social capital and bonds: A system of structure and strength




Appendix B: Conceptual Framework

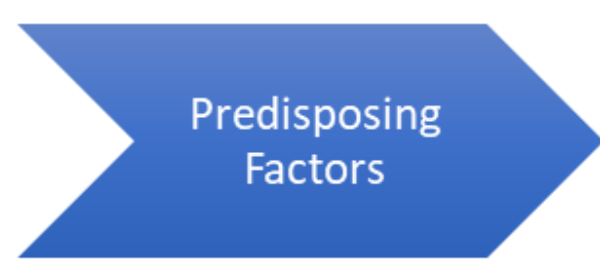

Child and Parent Sociodemographic Characteristics

Family Culture Characteristics

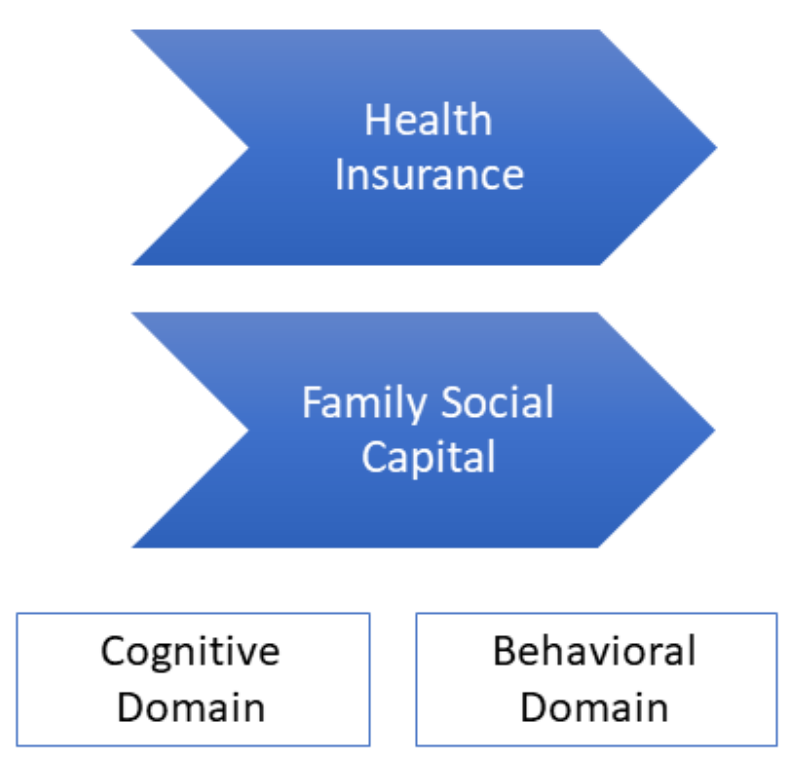

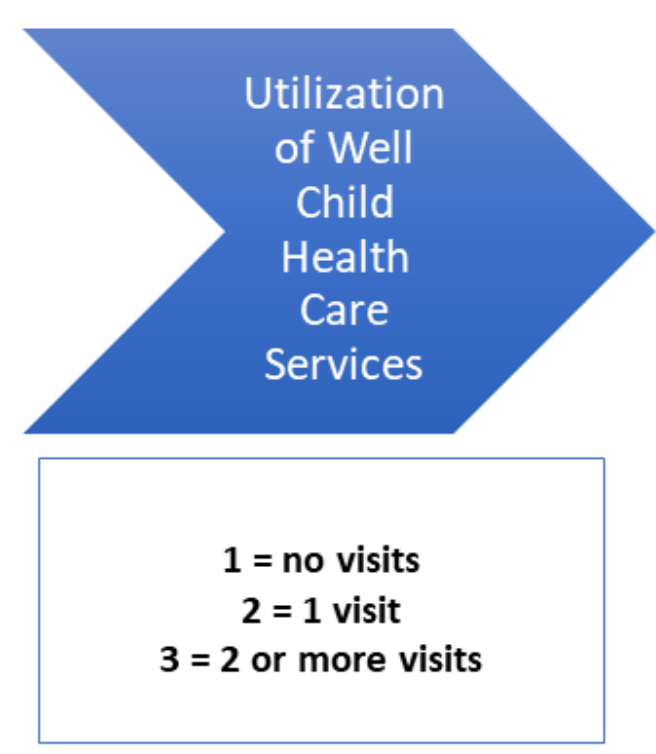




\section{Appendix C: IRB}

\section{IRB-2018-209 - Initial: Initial - Exempt}

irb@sandiego.edu <irb@sandiego.edu>

Thu, Jan 18,2018 at 8:52 AM

To: efrybowers@sandiego.edu, jgeorges@sandiego.edu, kwestphaln@sandiego.edu, mbarger@sandiego.edu

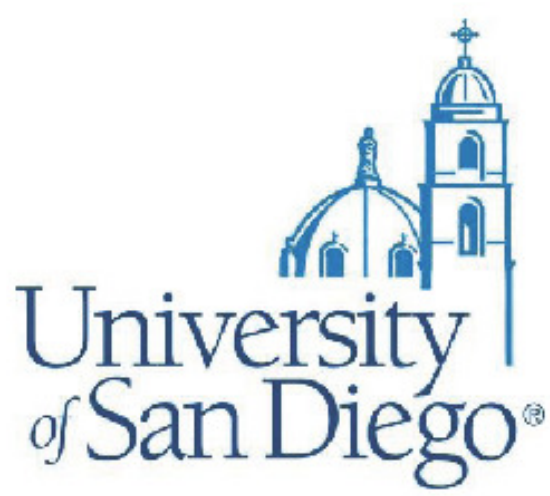

Jan 18, 2018 8:52 AM PST

Kristi Westphaln

Hahn School of Nursing \& Health Science

Re: Exempt - Initial - IRB-2018-209, Exploring the relationship between family social capital and utilization of well child preventative health care services

\section{Dear Kristi Westphaln:}

The Institutional Review Board has rendered the decision below for IRB-2018-209, Exploring the relationship between family social capital and utilization of well child preventative health care services.

Decision: Exempt

Selected Category: Category 4. Research involving the collection or study of existing data, documents, records, pathological specimens, or diagnostic specimens, if these sources are publicly available or if the information is recorded by the investigator in such a manner that subjects cannot be identified, directly or through identifiers linked to the subjects.

\section{Findings: None}

Research Notes:

Internal Notes:

Note: We send IRB correspondence regarding student research to the faculty advisor, who bears the ultimate responsibility for the conduct of the research. We request that the faculty advisor share this correspondence with the student researcher.

The next deadline for submitting project proposals to the Provost's Office for full review is N/A. You may submit a project proposal for expedited or exempt review at any time. 